\title{
Subfossil peatland trees as proxies for Holocene palaeohydrology and palaeoclimate
}

\author{
Johannes Edvardsson ${ }^{1}$, Markus Stoffel ${ }^{1,2,3^{*}}$, Christophe Corona ${ }^{1,4}$, Luca Bragazza ${ }^{5,6,7}$, Hanns \\ Hubert Leuschner ${ }^{8}$, Dan J. Charman ${ }^{9}$, Samuli Helama ${ }^{10}$ \\ ${ }^{1}$ Dendrolab.ch, Institute of Geological Sciences, University of Bern, Baltzerstrasse 1+3, 3012, Bern, Switzerland \\ ${ }^{2}$ Climatic Change and Climate Impacts, Institute for Environmental Sciences, University of Geneva, 66 Bvd Carl \\ Vogt, 1205 Geneva, Switzerland \\ ${ }^{3}$ Department of Earth Sciences, University of Geneva, rue des Maraîchers 13, CH-1205 Geneva, Switzerland \\ ${ }^{4}$ GEOLAB, UMR6042 CNRS, 63057 Clermont-Ferrand, France \\ ${ }^{5}$ Department of Life Science and Biotechnologies, University of Ferrara, Corso Ercole I d'Este 32, I-44121 Ferrara, \\ Italy \\ ${ }^{6}$ Swiss Federal Institute for Forest, Snow and Landscape Research, WSL Site Lausanne, Station 2, CH-1015 \\ Lausanne, Switzerland \\ ${ }^{7}$ Ecole Polytechnique Fédérale de Lausanne EPFL, School of Architecture, Civil and Environmental Engineering \\ ENAC, Laboratory of Ecological Systems ECOS, Station 2, CH-1015 Lausanne, Switzerland \\ ${ }^{8}$ University of Göttingen, Albrecht-von-Haller-Institute, Department of Palynology and Climate Dynamics, Untere \\ Karspüle 2, 37073 Göttingen, Germany \\ ${ }^{9}$ Geography, College of Life and Environmental Sciences, University of Exeter, EX4 4RJ, UK \\ ${ }^{10}$ Natural Resources Institute Finland, P.O. Box 16, 96301 Rovaniemi, Finland
}

*Corresponding author: markus.stoffel@dendrolab.ch

This document is the accepted manuscript version of the following article:

Edvardsson, J., Stoffel, M., Corona, C., Bragazza, L., Leuschner, H. H., Charman, D. J., \& Helama, S. (2016). Subfossil peatland trees as proxies for Holocene palaeohydrology and palaeoclimate. Earth-Science Reviews, 163, 118-140. https:// doi .org/10.1016/j.earscirev.2016.10.005

This manuscript version is made available under the CC-BY-NC-ND 4.0 1icense http://creativecommons.org/1icenses/by-nc-nd/4.0/ 


\section{Abstract:}

2 Due to the scarcity of reliable and highly resolved moisture proxies covering much of the

3 Holocene, there has been increased interest in the study of living and subfossil peatland trees

4 sensitive to gradual and extreme changes in hydrology, precipitation, and related environmental

5 processes. Peatland development and the associated carbon accumulation, which are strongly

6 influenced by hydrological fluctuations, are also of prime importance as peatlands represent long-

7 term sinks of atmospheric carbon. Improved knowledge of peatland development and soil

8 moisture variability during the Holocene is therefore essential to our understanding of long-term

9 hydroclimate changes, the terrestrial carbon cycle, and to enable more robust predictions of

10 peatland response to future climate changes.

11 Here, we review the existing mid- to late Holocene peatland tree-ring chronologies that

12 have been used to study climate variability on (sub-)annual to centennial scales with a primary

13 focus on northern Europe. Since the 1970s, absolutely dated tree-ring chronologies covering

14 substantial parts of the Holocene have been developed from excavated remains of oak (Quercus

15 spp.) and pine (Pinus sylvestris L.). The annual tree-ring patterns of these trees are often

16 characterized by periods of depressed growth reflecting annual to decadal hydroclimatic changes.

17 In addition, changes in the spatio-temporal distribution of trees throughout the Holocene are often

18 found to reflect decadal to centennial climate and hydrological changes. Moreover, synchronicity

19 between tree-ring chronologies and tree-population dynamics over larger geographical areas

20 show periods of coherent regional climate forcing, especially during the mid-Holocene.

21 This review (i) provides an overview of pioneering and recent studies presenting tree-ring

22 chronologies developed from subfossil peatland trees, and (ii) presents recent developments in the

23 fields of dendroecology (i.e. the response of tree growth and changes in vitality as a result of 24 changes in climatic variables) and dendroclimatology (i.e. the reconstruction of climate 
25 fluctuations based on tree-ring analyses) in peatland regions. Moreover, we (iii) use long-term

26 climate reconstructions based on alternative proxies for comparison, and (iv) present different

27 ways to analyse tree-ring records to generate novel information on annual to centennial

28 timescales. This analysis is based on an unprecedented network of tree-ring chronologies from

29 Denmark, Finland, Germany, Great Britain, Ireland, Lithuania, the Netherlands, Poland, Sweden,

30 and Canada, as well as a wealth of old and previously (un) published literature from Scandinavia

31 and Germany, which has not been accessible to a wider audience in the past due to inaccessibility

32 or linguistic barriers. Finally, a map of possible hotspots for the assessment of continuous

33 peatland-tree studies is presented, along with suggestions for new research directions in the field.

35 Keywords: Peatland; Raised bog; Palaeohydrology; Palaeoclimatology; Dendrochronology;

36 Subfossil trees; Quercus robur; Pinus sylvestris.

\section{Highlights}

39 - We review extensive peatland tree-ring chronologies from northern Europe covering 40 major parts of the Holocene.

41 - Long distance cross-matches (correlograms) and significant positive correlation point to $42 \quad$ larger-scale climate signals.

43 - Subfossil peatland trees can be used for detailed palaeoclimatic and palaeohydrological 44 reconstructions.

45 - Warm/dry conditions are favourable for peatland tree growth, but may turn peatlands from $46 \quad$ carbon sinks to carbon sources. 


\section{Introduction}

50 A prerequisite for any effort to distinguish natural climate variability from anthropogenic effects

51 is to reconstruct past climatic variations prior to industrialization (Jansen et al., 2007; Marcott et

52 al., 2013). In recent decades, improved palaeoclimatic methodologies and chronological

53 techniques have enabled the development of robust, accurate and detailed climate and ecosystem

54 reconstructions, and thereby increased our knowledge of climate dynamics over the course of the

55 Holocene (Wanner et al., 2008; Marcott et al., 2013). Several multi-proxy temperature

56 reconstructions have been created both in the northern and southern hemispheres for the last two

57 millennia (Moberg et al., 2005; D’Arrigo et al., 2006; Mann et al., 2008; Birks et al., 2014;

58 Stoffel et al., 2015), many of them being derived from tree rings and with annual resolution. The

59 vast majority of dendroclimatic studies have been used to infer past temperatures at high latitudes

60 (Briffa et al., 1990; D’Arrigo et al., 2006; McCarroll et al., 2013; Linderholm et al., 2014). A

61 much smaller proportion of time series can be used for the reconstruction of long-term, highly

62 resolved precipitation series (Büntgen et al., 2014; Cook et al., 2015), thereby hampering our

63 understanding of past moisture or hydrological variations.

64 Tree growth in natural peatlands strongly depends on water-table depth (Boggie, 1972;

65 Linderholm et al., 2002), such that rising water tables cause reduced growth due to hypoxia or

66 anoxia, whereas lowered water tables create relatively well-oxygenated peat-surface layers

67 promoting tree growth (Boggie, 1972; Leuschner et al., 2002). As a consequence, trees growing

68 on peatlands have been shown to respond to hydrological changes (Leuschner et al., 2002;

69 Eckstein et al., 2009; Edvardsson et al., 2015a) and can therefore be used for the construction of

70 time series of past moisture fluctuations.

71 Peatlands are not only valuable long-term climate archives (Aaby, 1976; Barber, 1981;

72 Charman et al., 2009). With an approximate coverage of 4 million $\mathrm{km}^{2}$ across Eurasia and North 
73 America (Lappalainen, 1996; MacDonald et al., 2006), they also constitute an important sink for 74 atmospheric carbon dioxide $\left(\mathrm{CO}_{2}\right)$ and a considerable source of methane $\left(\mathrm{CH}_{4}\right)(\mathrm{MacDonald}$ et 75 al., 2006; Yu et al., 2010; Limpens et al., 2011). In fact, peatlands store twice as much carbon (C) 76 as forests (Joosten and Couwenberg, 2008). Spatio-temporal dynamics of $\mathrm{CO}_{2}$ and $\mathrm{CH}_{4}$ fluxes in 77 peatlands are mainly driven by hydrological conditions, which can be expressed by water-table

78 levels (Mitsch et al., 2013). In addition to driving the carbon flux, water-table fluctuations in 79 peatland ecosystems also influence a wide range of environmental processes such as vegetation 80 patterns, the fixation of nitrogen, and the chemical composition of water passing through 81 peatlands (Limpens et al., 2011; Waddington et al., 2014). Consequently, reconstructions of past 82 water-table variations based on tree-ring records are of prime importance not only to improve our 83 understanding of climate variability, but also to the assessment of the functioning of peatlands in 84 a context of changing climatic conditions and under increasing levels of greenhouse gases.

86 In this context, the specific aims of this paper are to:

87 (1) Synthesize current knowledge on relationships between tree growth, hydrology, and 88 climate changes in peatlands from both an ecophysiological and dendroecological 89 perspective, to evaluate and document the potential of peatland trees as a proxy for water 90 table and/or regional hydroclimatic reconstructions;

91 (2) Review and map past work on peatland tree-ring chronologies across the Northern 92 Hemisphere. We include studies from e.g. Germany and Scandinavia, written in languages 93 other than English, to make them accessible to a wider audience;

94 (3) Compare the spatial and temporal distribution of peatland forests at regional to 95 hemispheric scales, to remove site effects and to interpret results in a longer-term climatic 96 context; 
(4) Compare regional patterns of change with hydrological proxies covering the same period to test how the tree-ring records capture changes in (hydro)climatic variables;

(5) Discuss the potential of tree-ring records derived from peatland trees for palaeoclimatic and palaeohydrological reconstructions over the course of the Holocene, and to illustrate related possibilities, benefits, and limitations of subfossil peatland trees in achieving these goals;

(6) Conclude with a call for further research directions and for work in new geographic

\section{Peatlands, peat, structure and development}

108 plants and contains less than $20-30 \%$ of minerals (= ash content) (Warner, 2003). The chemical

109 and physical properties of peat are highly variable in space and time, depending on the type of

110 plant species contributing to its formation, the degree of decomposition, and the geochemistry of

111 water supply. In an undisturbed peatland, peat is primarily composed of water (88-97\%), dry

112 matter (2-10\%), and gas (1-7\%). Peat changes in composition over time with very slow

113 decomposition, compaction, and geochemical alteration, such that it eventually forms coal after

114 several million years. Based on the dominant botanical composition and degree of decomposition,

115 four main categories of peat can be described: moss, herbaceous, wood, and humified peat

116 (Charman, 2002; Loisel et al., 2014). In humified peat, the plant remains are so decomposed that

117 the bulk of plants are no longer identifiable.

A peatland can be defined as an area covered by at least $30 \mathrm{~cm}$ of peat (Joosten and Clark,

119 2002; Charman, 2002). Peatlands, in a broader context, are a type of wetland characterized by 120 organic soil. The term "mire" is sometimes used to indicate a peatland with active accumulation 
121 of peat, but for our purposes the two terms are equivalent. On a global scale, three main regions

122 of peatland development can be distinguished; northern peatlands, primarily distributed in boreal

123 and subarctic climate in the Northern Hemisphere (Fig. 1), tropical peatlands (primarily

124 distributed in Southeast Asia, but also in South America and Africa), and Southern peatlands

125 (primarily distributed in Patagonia, but also in temperate Australasia) (Yu, 2011). Estimates of

126 the global peatland area are highly variable due to the different wetland classification systems and

127 insufficient survey data (Lappalainen, 1996; Rydin and Jeglum, 2006), but it is generally agreed

128 that total peatland area is approximately 4 million $\mathrm{km}^{2}$, corresponding to c. $2.7 \%$ of the Earth's

129 land surface (Lappalainen, 1996; MacDonald et al., 2006). Estimates for tropical regions are

130 subject to much greater error than those for northern peatlands. Of the total peatland area, $1.5 \%$ is

131 found in Africa, 28\% in Asia, 0.4\% in Australia and Oceania, 2.6\% in Central and South

132 America, 24\% in Europe, and 44\% in North America (Lappalainen, 1996).

133 Peatland initiation patterns differ for the three main regions because of different histories

134 of ice cover recession and climate change over the glacial-interglacial transition (Fig. 2).

135 Northern peatlands show an initiation peak around 9050-7050 BCE (11,000-9000 years before

136 present, BP), South American peatlands around 15,050-12,550 BCE (17,000-14,500 years BP),

137 and many tropical peatlands started to form more than 18,050 BCE (20,000 years BP; Yu et al.,

138 2010). The average peat accumulation rate is c. $13 \mathrm{~g} \mathrm{C} \mathrm{m}^{-2} \mathrm{yr}^{-1}$ in tropical peatlands and c. 19-22

$139 \mathrm{~g} \mathrm{C} \mathrm{m}^{-2} \mathrm{yr}^{-1}$ in northern and southern peatlands (Yu et al., 2010; Loisel et al., 2014). A

140 conservative estimate of overall peat C pool indicates that world peatlands store c. $610 \mathrm{GtC}$,

141 primarily in northern peatlands (c. 89\%) with a small amount in tropical (c. 8\%) and southern (c.

$1423 \%$ ) peatlands ( $\mathrm{Yu}$ et al., 2010). Overall, although covering only c. $2.7 \%$ of the Earth's land

143 surface, peatlands store at least $25 \%$ of global soil organic C (Hiederer and Köchy, 2012). 
On the basis of vegetation composition, hydrology, peat, and water chemistry, northern

145 peatlands (which are the focus of this review) can be distinguished into two major types:

146 minerotrophic peatlands (= fens) and ombrotrophic peatlands (= bogs). Minerotrophic peatlands

147 receive their water and nutrient input from both atmospheric deposition and surrounding 148 groundwater, whereas ombrotrophic peatlands are fed entirely from atmospheric deposition

149 (Rydin and Jeglum, 2006). The main consequence of such different hydrological pathways is that

150 fens are richer in dissolved minerals and have a higher water $\mathrm{pH}$ than bogs. These geochemical

151 differences are reflected in the floristic composition; fens are typically dominated by vascular

152 plants (particularly sedges) and brown mosses (Amblystegiaceae family), whereas bogs are

153 usually dominated by peat mosses (Sphagnaceae family) and a smaller vascular plant component.

154 The role of vascular plants, such as dwarf shrubs, has however gained increased interest recently

155 because they seem to have competitive advantages in response to climate warming (Breeuwer et

156 al., 2010; Buttler et al., 2015). In both fens and bogs, tree cover is often limited, but there are

157 densely tree-covered peatlands in the boreal region (Fig. 3). Under natural conditions, the most

158 common tree species colonizing peatlands in Eurasia are Scots pine (Pinus sylvestris L.),

159 Mountain pine (Pinus uncinata Ramond ex DC.), Dwarf mountain pine (Pinus mugo Turra), and

160 Siberian pine (Pinus sibirica Du Tour), whereas Mountain birch (Betula pubescens Ehrh.),

161 willow (Salix spp), and black alder (Alnus glutinosa L.) often colonize fens. Other tree species on

162 northern peatlands include black spruce (Picea mariana (Mill.) Britton, Sterns and Poggenb.),

163 whereas Tamarack (Larix laricina (Du Roi) K.Koch) sometimes colonizes fens. In this review,

164 Scots pine and oak (Quercus robur L. and Q. petraea L.) will be in primary focus, as these

165 species are commonly excavated in northern peatlands and are suitable for dendrochronological

166 studies (Table 1). Excavated trunks and plant macrofossils show that oak trees once colonized

167 significant peatland areas in northwest Europe (Pilcher et al., 1984; Leuschner et al., 2002). 
168 However, analogous peatland ecosystems do not appear to exist any longer (Sass-Klaassen and 169 Hanraets, 2006).

170 The presence of Sphagnum is particularly important for peat accumulation in 171 ombrotrophic peatlands. Sphagnum plants have the capacity to acidify the surrounding water as a 172 result of an extremely efficient cation exchange capacity (van Breemen, 1995; Rydin and Jeglum, 173 2006). This enables Sphagnum to absorb nutrients from very low concentrations in the water 174 source, and produces a litter that is resistant to decay. Sphagnum also increases soil anoxia by 175 storing water in empty cells (hyalocysts). Because Sphagna, like all bryophytes, cannot regulate 176 their water balance, their development is possible whenever there is a surplus of water. In 177 addition, because they are most competitive under acidic conditions $(\mathrm{pH}<4-5)$, most Sphagnum 178 species benefit from the presence of low mineral content. This combination of hydrological and 179 geochemical conditions is prevalent on ombrotrophic peatlands (van Breemen, 1995). The 180 physiological requirements of Sphagnum are one of the key determinant of the global distribution 181 of northern ombrotrophic peatlands, which are typically located north of $45^{\circ} \mathrm{N}$, in particular at $18250^{\circ}-70^{\circ} \mathrm{N}$ (Yu et al., 2011), under climatic conditions and landscape morphology that promote a 183 surplus of water and low mineral availability. However, whilst Sphagnum is a key taxon for 184 northern peatland formation, the presence of Sphagnum is not a pre-requisite for peat 185 accumulation and some extraordinary examples exist where peat forms from plants such as e.g., 186 Poaceae (Smith and Clymo, 1984). Peat can be formed by a range of other vascular plants as 187 well, particularly sedges in fens and wood in peatlands with shrub and tree cover. Peat derived 188 from woody plants is especially important in the tropics. Specific taxa, such as the restiad rushes 189 in Australasia, are also important peat formers in some regions (Clarkson, 2004). Peat 190 accumulation can be equally fast in these peat types (Loisel et al., 2014) and prevailing climate 191 appears to be a more important driver of peat accumulation rates over millennial timescales than 
192 botanical composition (Charman et al., 2013, 2015). The presence of waterlogged conditions

193 (persistent soil anoxia), low chemical quality of peat moss litter, and low $\mathrm{pH}$, all hamper the

194 microbial decomposition of plant remains, thereby favouring the long-term accumulation of peat

195 (a sink of atmospheric C) and the preservation of plant macro- and micro-fossils creating an 196 archive of past environmental conditions, especially in ombrotrophic northern peatlands 197 (Chambers and Charman, 2004; Chambers et al., 2012).

A complex microtopography often develops on the surface of ombrotrophic peatlands,

199 created by a process of differential growth and decay, sometimes enhanced by physical processes

200 such as freezing. Microhabitats of pools, hollows, lawns, and hummocks are formed in relation

201 to a water table gradient, which in turn drives vegetation composition and the spatial distribution

202 of plants (Bragazza and Gerdol, 1999). Pools form in the wettest areas of peatlands (Fig. 3),

203 characterized by standing water with only free-floating peat mosses and vascular plants. Hollows,

204 lawns, and hummocks occur along a gradient of decreasing wetness and are often characterized

205 by a continuous and dense layer of Sphagnum plants, and a sparse cover of vascular plants. Along

206 the gradient from hollows to hummocks, Sphagnum species become more drought-adapted and

207 vascular plants become more shrubby and abundant. In the driest locations, Sphagnum is absent

208 and may be replaced by more drought tolerant mosses. In such a typical sequence of

209 microhabitats on ombrotrophic peatlands, the presence of trees is determined by the moisture

210 content of the peat due to the sensitivity of tree roots to anoxic conditions (Boggie, 1972; Vitas

211 and Erlickytë, 2007).

212 Where hydrological conditions are stable, tree distribution is limited to the hummocks and

213 individual trees tend to be small and slow growing. Where changes in hydrological conditions

214 occur, the expansion of trees is favoured by any reduction in soil water content, such as decreased

215 precipitation or increased evapotranspiration (Boggie, 1972; Edvardsson et al., 2015a). Peatlands 
216 with consistently dry surface conditions can be heavily forested with relatively large trees,

217 especially in boreal environments. The dominant hydrological control on tree growth means that

218 the direct effect of temperature is less important, whereas lowering of the water table will

219 promote expansion of tree cover and increased tree growth rates (Smiljanić et al., 2014;

220 Edvardsson et al., 2015a, b). This theoretical concept has been confirmed by observations of tree

221 growth following peatland drainage (Dang and Lieffers, 1989; MacDonald and Yin, 1999;

222 Freléchoux et al., 2000). Lowering of the water table increases soil temperature, improves soil

223 aeration, and increases nutrient availability through organic matter mineralization (Grootjans et

224 al., 1985; Choi et al., 2007; Weedon et al., 2012), with positive effects on tree growth.

225 Although success of tree seed germination does not differ between lawns (wet

226 microhabitats) and hummocks (drier microhabitats), the performance of tree seedlings and the

227 probability of maturation is greater on hummocks (Holmgren et al., 2015). Positive feedbacks

228 have also been shown between tree recruitment and dwarf shrubs on hummocks (Holmgren et al.,

229 2015). Once they are established, trees can cause a further drying of the peat due to enhanced

230 transpiration (Moir et al., 2010; Limpens et al., 2014a), promoting even greater tree 231 encroachment.

232 Peatland development over time is driven primarily by successional processes and climate

233 dynamics (Fig. 2; Hughes, 2003). Historically, the conventional successional sequence is via

234 terrestrialisation of aquatic systems and fen peat formation to bog peat (Walker, 1970), but it is

235 now commonly accepted that a wide variety of successional sequences can occur in different

236 peatlands. Paludification (i.e. the gradual spread of peatland through waterlogging of previously

237 dry ground) is the other main process leading to peat formation particularly in many boreal

238 peatlands and blanket bogs. The occurrence and preservation of trees is influenced by 239 successional stages, with tree growth occurring most likely in the later stages of succession, when 
240 drier surfaces are more prevalent. In paludified peatlands, tree remains typically occur at the base

241 of the sequence, as they were growing on the drier surfaces prior to peat formation. Moreover,

242 trees can be preserved in peatlands even if they were not growing on the surface. For example,

243 trees can fall into the margins of ponds or fens and may therefore be preserved in peat and

244 sediment formed during the early aquatic stages of peatland growth.

246 3. Historical background: Pioneering to recent studies

247 Since the late nineteenth century, palaeobotanic and climatic research has been performed in 248 peatlands, initially with a focus on Nordic countries (Dau 1829; Vaupell 1851; Blytt, 1876;

249 Sernander, 1890, 1893; von Post 1924, 1930), and later in other regions of the northern

250 hemisphere (Lewis, 1906, van Geel, 1978; Barber et al., 1994; Yu et al., 2014; Loisel et al., 251 2014). Most often, such studies have been based on plant macrofossils, pollen grains or peat 252 decomposition, but the attention of many pioneer researchers was attracted by the presence of 253 subfossil trees (Fig. 2 and 4) in peat stratigraphy (Dau 1829; Vaupell 1851; Blytt 1876; see also 254 Birks and Seppä, 2010; Nielsen and Helama, 2012).

255 For example, Dau (1829) presented pioneering studies where he described the 256 stratigraphic distribution of tree trunks in Danish peat bogs, and Vaupell (1851) studied buried 257 trees and their relationship with soil nutrients, sunlight, and moisture conditions (Nielsen and 258 Helama, 2012). Steenstrup (1842) classified tree horizons on the basis of species composition and 259 interpreted tree population shifts as environmental changes associated with temperature and 260 hydrological shifts during the postglacial period (Birks and Seppä, 2010; Nielsen and Helama, 261 2012). For these observations, Steenstrup can be considered as one of the founders of Holocene 262 palaeoecology and climate research (Birks and Seppä, 2010). In Norway, Blytt (1876) 263 investigated tree horizons in relation to variations in peat decomposition, and interpreted 
264 synchronous changes as shifts controlled by climate. The Swedish researcher Sernander thereafter 265 improved the methods introduced by Blytt (1876) and associated dark peat layers containing 266 wood material with periods of relatively dry continental climate, whereas less humified peat 267 layers without fossil trees were interpreted as humid climatic periods (Sernander, 1890, 1893). 268 Sernander also developed a schematic model of postglacial climate change, known as the Blytt269 Sernander scheme, which has been used by many generations of Quaternary geologists and 270 palaeobotanists (e.g., Smith and Pilcher, 1973; Blackford and Chambers, 1991; Birks and Seppä, 271 2010). Outside Scandinavia, pine trees exposed in erosion scars in blanket peats across the 272 Scottish Highlands (Lewis, 1906, 1908) were interpreted as evidence of constant changes in the 273 character of the vegetation covering the Scottish peatlands.

274 During the early twentieth century, palaeoclimatological research was improved 275 significantly by pollen analysis, introduced by von Post (1924, 1930). Moreover, stratigraphic 276 studies by Granlund (1932) showed that abrupt peat humification shifts, referred to as "recurrence 277 surfaces" (Fig. 2), were associated with rapid climatic shifts towards colder and wetter 278 conditions. Following the introduction of radiocarbon dating, the studies by e.g., Aaby (1976) and 279 Barber (1981) were able to link peat humification shifts to actual climate changes. Currently, 280 climate reconstructions based on peatlands are common in the palaeoclimatic literature (e.g., 281 Langdon and Barber, 2005; Mauquoy et al., 2008) and generally based upon several parameters 282 such as peat humification, pollen data, plant macrofossils, and testate amoebae (e.g., Hughes et 283 al., 2006; Swindles et al., 2013).

284 Even though tree horizons in peat deposits were discovered over a century ago and their 285 potential role as indicators of environmental changes was rapidly realized, subfossil trees in 286 peatlands remained an underutilized source of palaeoclimatic information for a long time. Then, 287 in the late 1960s, a number of projects were initiated with the aim of developing tree-ring 
chronologies using subfossil trees excavated from peatlands in northwest Europe (Pilcher, 1973;

289 Pilcher et al., 1977). This approach was made possible by the large number of well-preserved tree 290 remains that have been exposed by peat extraction for fuel and horticulture (Fig. 4-5, Joosten and 291 Clarke, 2002). During the 1970s and 1980s, oak samples from such peatlands in Ireland and 292 Germany were used for the establishment of the first multi-millennial peatland tree-ring 293 chronologies (Pilcher 1973; Pilcher et al., 1977, 1984; Leuschner and Delorme, 1984). At a very 294 early stage, dendrochronological studies proved that subfossil wood material originating from 295 different Irish peatlands could be cross-dated (Pilcher, 1973; Pilcher et al., 1977), which 296 encouraged further work. Cross-dating is a standard procedure in dendrochronology in which 297 individual tree-ring width (TRW) series are statistically and visually compared (Douglass, 1941; 298 Fritts, 1976; Wigley et al., 1987). Several statistical parameters are normally tested, of which the 299 t-test (Baillie and Pilcher, 1973) is the most commonly used (Table 1) and referred to when cross300 dating statistics are presented (Fig. 6-7).

301 During the 1970s, floating tree-ring chronologies were developed from oaks found in 302 multiple peatlands across Ireland (Pilcher, 1973; Pilcher et al., 1977). In parallel, an Irish oak 303 chronology from living and archaeologically excavated trees was developed by Baillie (1973, 304 1995), which would later enable absolute dating of some of the floating chronologies to obtain a 305 continuous tree-ring chronology spanning 7272 years (Pilcher et al., 1984). The chronology 306 proved to be a valuable calendric climate record and provided a standard for the radiocarbon 307 calibration curve (Pilcher et al., 1984; Pearson et al., 1986; Reimer et al., 2013). As the Holocene 308 record of subfossil peatland trees is of significance to both palaeoclimatologists and archeologists 309 the literature contains a mixture of chronologies that quote ages as both $\mathrm{BP}$ and $\mathrm{CE} / \mathrm{BCE}$. 310 Although, for the purposes of a review it may seem appropriate to adopt one scheme or the other, 311 however, this has inherent problems for both of the relevant communities. Consequently, in this 
312 study where we refer to an absolute age we quote the age in $\mathrm{CE} / \mathrm{BCE}$ with the $\mathrm{BP}$ alternative in

313 brackets, but where an event is known by a BP age, we quote the cal. BP age (calibrated years

314 before $\mathrm{AD} 1950$ ) and refer to an approximate BCE age in brackets.

315 Meanwhile, tree-ring chronologies for environment and climatic reconstructions were also

316 constructed in Germany (Bauerochse et al., 2015). In this case, thousands of trees preserved in

317 central and north German riverine sediments (Becker and Schirmer, 1977; Becker, 1983;

318 Friedrich et al., 2004) and in north German peatlands (Leuschner and Delorme, 1984) were used.

319 Due to stepwise and long-distance cross-dating it was possible to age determine previously

320 undated material and to correct problematic and falsely dated sections (Fig. 6-7; Pilcher et al.,

321 1984; Brown and Baillie 2012). Ever since then, the use of stepwise cross-dating has given an

322 absolute age to tree-ring chronologies from England (Chambers et al., 1997; Lageard et al. 1999;

323 Boswijk and Whitehouse, 2002), Scotland (Moir et al., 2010; Moir, 2012) the Netherlands

324 (Jansma, 1996; Sass-Klaassen and Hanraets, 2006), Denmark (Christensen, 2007) and Sweden

325 (Edvardsson et al., 2012a, 2014b).

326 In the late 1960s, Munaut (1967) and Smith et al. (1972) successfully developed the first

327 tree-ring chronologies from subfossil peatland pines. However, pine trees were often considered

328 as unreliable for chronology construction due to problems such as missing and wedging rings

329 (Fig. 5). Attempts in Scotland during the 1980s, for example, failed to cross-date approximately

330200 samples (Bridge et al., 1990). Radiocarbon dates later showed that the samples had a large

331 temporal range, which explained parts of the problems with cross-dating. By contrast, more

332 recent studies focusing on Irish, Scottish, and British peatland pine chronologies have been

333 successful in cross-dating tree-ring records (Pilcher et al., 1995; Lageard et al., 2000; Moir et al.,

334 2010). 
The interest in peatland pines increased, especially as they were found to have the

336 potential to extend further back in time than the Irish oak chronology (then at $5452 \mathrm{BCE}$ or 7401

337 BP; Pilcher et al., 1995). In the Lower Saxony area, northwest Germany, extensive work was

338 initiated on peatland pines (Leuschner et al., 2007; Eckstein et al., 2009, 2011; Achterberg et al.,

339 2015, 2016). The German pine chronologies have been constructed from some 4000 peatland

340 trees (Bauerochse et al., 2015) and show a temporal spread over the period 6703-1165 BCE

341 (8652-3114 BP; Achterberg et al., 2016). Scots pine has been shown to represent by far the most

342 common tree species in Scandinavian (Gunnarson, 1999; Edvardsson et al., 2012a) and Baltic

343 (Pukienè, 1997; Edvardsson et al., 2016a) peatlands and in northern Sweden, pine remains in

344 peaty environments have been used for treeline reconstructions during the Holocene (Kullman,

345 1987). However, these trees have proved to be unsuitable for chronology development due to of

346 the smaller sample number and wide temporal range. In central and southern Sweden, by contrast,

347 peatland pines have been used successfully for the development of multi-millennial tree-ring

348 chronologies (Gunnarson 1999; 2008; Edvardsson et al., 2012a, b). In northern Finland, subfossil

349 pine remains have been recovered from peatlands and lacustrine sediments of lakes with thick

350 layers of organogenic riparian substrate (Eronen et al., 1999). Dendrochronological analyses of

351 this material yielded a continuous tree-ring chronology over the mid- and late-Holocene (from

3525634 BCE, Eronen et al., 2002; Helama et al., 2008), with indications that pine population

353 density and hydrologic conditions varied over time (Helama et al., 2005). The suitability of

354 subfossil peatland pines for long-term climate and palaeohydrology reconstructions has now been

355 shown in a range of studies (Pilcher et al., 1995; Lageard et al., 2000; Boswijk and Whitehouse,

356 2002; Leuschner et al., 2007; Eckstein et al., 2009; Moir et al., 2010; Edvardsson et al., 2012a;

357 Achterberg et al., 2016).

358 


\section{4. General interpretations of peatland tree-growth dynamics}

364 High water levels in peatlands have profound effects on seed germination and seedling

365 development (Kozlowski, 1997; Holmgren et al., 2015). Indeed, the activation of the

366 physiological processes required for seed germination depends on oxygen $\left(\mathrm{O}_{2}\right)$ supply. A water

367 table located close to the peat surface will restrict $\mathrm{O}_{2}$ availability to the embryo and thereby 368 prevent or postpone seed germination (Dang et al., 1991; Kozlowski and Pallardy, 1997;

369 Fragnière et al., 2015; Kozlowski et al., 2015). Only once the seeds germinate will fluctuations in 370 water level determine seedling survival and modify the capacity of seedlings to elongate rapidly 371 and protrude above the water level (Sacchi and Price, 1992). As a consequence, lowered water

372 tables are typically associated with the colonization of trees due to improved growth conditions 373 (Freléchoux et al., 2000; Eckstein et al., 2009; Edvardsson et al., 2015b).

374 Most often, the annual growth of peatland trees is highly dependent on the depth and 375 variability of the water table beneath the tree root system (Boggie, 1972; Eckstein et al., 2009).

376 Wetter conditions are usually characterized by growth patterns showing recurrent, narrow annual 377 growth rings, multi-annual growth depressions, and sometimes missing rings (Leuschner et al., 378 2002; Fig. 5). Such moist and unfavourable growth conditions are associated with physical, 379 chemical, and biological restrictions on tree growth, of which reduced availability of nutrients in 380 the water unsaturated zone probably represents the most important limiting factor (Boggie, 1972;

381 Mannerkoski, 1991; Linderholm, 2001). Moreover, nitrate is rapidly depleted by denitrification 382 under conditions of soil hypoxia (Kozlowski and Pallardy, 1984). By contrast, the uptake of iron 
$383(\mathrm{Fe})$ and manganese $(\mathrm{Mn})$ is increased because of an increase in soluble ferric and manganic

384 forms. Yet, abundant ferrous and manganous ions in wet soils may be toxic to some tree species

385 (Crawford, 1989). Moist conditions reduce root growth of most woody plants by inhibiting root

386 formation and branching, repressing growth of existing roots and mycorrhizae, and by promoting

387 root decay (DeBell et al., 1984; Kozlowski, 1984; Kozlowski and Pallardy, 1997; Eckstein et al.,

388 2011). Tree growth is inhibited by the lack of $\mathrm{O}_{2}$ (Dang et al., 1991; Kozlowski and Pallardy,

389 1997) and in particular, reduced macronutrients uptake (especially nitrogen, phosphorus, and

390 potassium) driven by a reduction in $\mathrm{O}_{2}$ supply to the roots (e.g., Osundina and Osonubi, 1989).

391 Finally, a variety of toxic compounds such as aldehydes, organic acids, and ethanol accumulated

392 in wet soils have been demonstrated to variously contribute to injury, growth reduction, and

393 mortality of woody plants (Kozlowski, 1997; Vitas and Erlickytë, 2007).

394 Consequently, a change toward wetter climatic conditions would lead to rising water

395 tables, causing shallower unsaturated zones (Schouwenaars, 1988; Hunt et al., 1999), and thereby

396 reduce recruitment of new trees and growth reductions in trees already growing at the peat

397 surface (Boggie, 1972; Linderholm et al., 2002; Edvardsson et al., 2015a). Soil moisture is

398 therefore a key driver of both radial tree growth and tree population dynamics in peatlands.

399 Growth depressions and dying-off phases in subfossil chronologies are therefore an expression of

400 unfavourable growth conditions, linked to changes in site hydrology towards moister conditions

401 (Leuschner et al., 2002; Edvardsson et al., 2012b; Scharnweber et al., 2015). Lowered water

402 tables, on the other hand, are typically associated with enhanced radial growth or the colonization

403 of peatland trees (Freléchoux et al., 2000; Eckstein et al., 2009; Edvardsson et al., 2015b). This

404 hypothesis is supported by a comparison of climate-growth relationships obtained for pine trees

405 growing on peat and adjacent mineral soils (Fig. 8). This comparison also clearly demonstrates

406 that tree growth on mineral soils is significantly correlated with winter and early summer 
407 temperatures, whereas a more complex, weaker and clearly site-dependent response to monthly

408 temperature and precipitation is detected in peatland trees. The latter presumably reflects the 409 multiannual synthesis of moisture variability and changing hydrology (Fig. 9), which could be

410 further complicated by a hydrological lag and/or feedback response in peatlands (Linderholm et 411 al., 2002; Edvardsson et al., 2015a; Edvardsson and Hansson, 2015).

412 Studies exploring climate-growth relationships have not been realized for subfossil 413 peatland oaks so far. Indeed, during extended periods of the Holocene, deciduous oaks have 414 established in peatlands across northwestern Europe (Pilcher et al., 1984; Leuschner et al., 2002),

415 but any detailed interpretation of the subfossil oak data has long been problematic due to the 416 absence of modern peatlands with oak tree cover (Sass-Klaassen, 2004). In a study by

417 Scharnweber et al. (2015), however, a catastrophic rewetting of a drained, oak covered peatland 418 in northeast Germany has provided the opportunity to study growth responses in oaks following 419 well-documented hydrological changes. Similar to the work on pine, moisture is also shown to be 420 the main growth-limiting factor in peatland oak trees.

422 4.2. Hydrological lag effects

423 Several studies show that a hydrological lag response to changing precipitation in peatlands 424 exists, meaning that some delay can be observed between actual climate changes and related 425 hydrological shifts in the peatlands (Kilian et al., 1995; Waddington et al., 2014). Such delayed 426 responses have in the past been attributed to (i) water transport in soils towards the peatlands 427 (e.g., Cowan, 1965; Hillel, 1971), (ii) water interception or accumulation in plants (Shukla and 428 Mintz, 1982; Seneviratne et al., 2010), (iii) delays between snowfall and associated snowmelt 429 (Price and Schlotzhauer, 1999), and (iv) the process by which water is replacing air in the 430 relatively large pore spaces of the unsaturated zone of peat (Ingram, 1983; Almendinger et al., 
431 1986). In addition, it is known that (v) peat soils are compressible such that changes in water

432 content may result in volumetric fluctuations and thereby variations in surface elevation, which in

433 turn can vary depending on the amount of water stored in the peat (Almendinger et al., 1986;

434 Price and Schlotzhauer, 1999). These slow hydrological changes may therefore result in monthly

435 to multiannual lags between climate and tree growth responses, as observed and discussed in

436 studies by Linderholm et al. (2002), Edvardsson et al. (2014a, 2015a), or Edvardsson and

437 Hansson (2015). Knowledge about such delays is important for our understanding of relations

438 between hydrological variability and tree growth, and for all studies aiming at; (i) reconstructing

439 past and future hydroclimate changes, (ii) long-term carbon storage capacity of northern

440 peatlands, (iii) the prediction of future peatland vegetation dynamics, and (iv) an improved

441 understanding of peatland vulnerability to changing climate (Waddington et al., 2014).

\subsection{The influence of trees on peatland hydrology}

444 As discussed, surface moisture in peatlands is the most important factor governing tree growth 445 and colonization (Boggie, 1972; Edvardsson et al., 2015b). Tree density may in turn influence 446 surface moisture and ultimately carbon sequestration in the peatlands, as a result of feedback 447 effects (Limpens et al., 2014a; Holmgren et al., 2015). Trees can affect the moisture status of 448 peatland environments through transpiration and interception (Limpens et al., 2014b).

449 Colonisation by trees therefore has the potential to cause a positive drying feedback, whereby 450 increased root uptake for transpiration demand causes a lowering of the water table, in turn 451 promoting improved tree growth and seedling recruitment and/or shrubification as root 452 oxygenation and root zone thickness increase (Limpens et al., 2014b). This positive feedback is 453 amplified further by; (i) increased soil nutrient availability by litter fall, (ii) increased levels of 454 interception with increased canopy (Dubé et al., 1995), and (iii) reduced aerodynamic resistance 
455 (by e.g., wind) favoured by higher stand density which increases evaporation (Kellner, 2001).

456 The change in hydrology may also lead to increased decay rates in the upper peat profile due to a

457 deepening of the aerobic zone. Changes in tree cover can therefore be a fundamental shift in the

458 peatland carbon cycle and it is possible that tree-covered peatlands could become net sources of

459 carbon if increased net photosynthetic rates and carbon fixation are lower than increased peat

460 decomposition rates (Juutinen et al., 2010). The effects that tree density has on water loss have

461 important implications for the structure and functioning of peatlands but the relation between

462 evapotranspiration and tree density is non-linear (Limpens et al., 2014b). This is because

463 increasing density of tree stands can result in shading of the peat surface, thereby reducing the 464 energy available for evaporation (Ohlson et al., 2001; Strakova et al., 2012).

\section{Climate - peatland relations: drawing a continental-scale picture}

469 The present interglacial, the Holocene, started about 11,700 cal BP (calibrated years before AD 470 1950) with a rapid transition from the cold Younger Dryas to subsequent conditions characterized 471 by significantly warmer and more stable conditions (Bond et al., 2001; Wanner et al., 2008; 472 Marcott et al., 2013). At the millennial timescale, the climate of the Holocene has been influenced 473 strongly by hemispheric trends in solar insolation, but was also interrupted by shorter centennial 474 events related to other drivers such as solar and volcanic forcing (Dansgaard et al., 1989; Bond et 475 al., 2001; Wanner et al., 2011). High spatial and temporal variability temperature and moisture 476 records covering the Holocene have been reconstructed from archives such as ice cores, ocean, 477 lake, and peat sediment cores, speleothems and glacier fluctuations (Wanner et al., 2011). 478 Climatic and environmental mismatches or delays between different geographical regions, 
479 however, underline the importance of multiple site studies and call for high-resolution

480 reconstructions using proxies such as tree rings, which remain the most widespread source of

481 annual resolution, precisely dated palaeoclimatic data. In the following discussion, the Holocene

482 is subdivided into the early (c. $9750-6250 \mathrm{BCE}$ or $11,700-8200$ cal. BP), mid (c. $6250-2250 \mathrm{BCE}$

483 or $8200-4200 \mathrm{cal}$. BP), and late (c. 2250 BCE or 4200 cal. BP to present) Holocene as suggested

484 by Walker et al. (2012).

485

486

5.1. The early Holocene

487 Subfossil peatland trees from the early Holocene are scarce for obvious reasons, primarily due to 488 the fact that most northern peatlands were not ombrotrophic until later periods of the Holocene 489 due to slow peat formation and accumulation (Barber et al., 2003; Yu et al., 2010). Despite this 490 limitation, radiocarbon dated pine trees as old as c. $9050 \mathrm{BCE}(11,000$ cal. BP) have been 491 discovered in northwestern German peatlands (Achterberg et al., 2016). The formation of raised 492 bogs in this region, however, only began about 2000 years later (Petzelberger et al., 1999; 493 Eckstein et al., 2011), which suggests that the material consists of mineral soil pines overgrown 494 by and preserved in expanding peatlands. Tree colonization directly on peat soils of northwestern 495 Germany has, however, been recorded about c. $6750 \mathrm{BCE}$ (8700 cal. BP), evident from peatland 496 pines dated to $6703 \mathrm{BCE}$ (8652 BP; Achterberg et al., 2015) and oaks dated to $6627 \mathrm{BCE}$ (8576 497 BP; Leuschner et al., 2002; Achterberg et al., 2015). Oak trunks from this period, but dated by 498 radiocarbon, have also been discovered in Denmark (Christensen, 2007). Some centuries later, 499 about $6350 \mathrm{BCE}$ (8300 cal. BP), minor periods of pine establishment have been noted in the Irish 500 and Scottish pine material (Bridge et al., 1990; Torbenson et al., 2015). Otherwise, few 501 establishment phases have been recorded prior to the 8200 cal. BP cold event (referred to as the 5028.2 ka event, c. 6250 BCE; Alley et al., 1997), which may have generated moist and unfavourable 
503 conditions for tree colonization at the peatlands. The $8.2 \mathrm{ka}$ event is recorded on a hemispheric

504 scale in a broad range of proxy records (Alley et al., 1997; Veski et al., 2004; Nicolussi and

505 Scüchter, 2012). The number of German pines recorded (replication in Fig. 10) drops during (or

506 slightly after) the 8.2 ka event and a 108-year gap has been documented in the German bog oak

507 record (Achterberg et al., 2016), indicating a shift towards unfavourable conditions for peatland

508 tree growth (Fig. 10). Although from a different context, the lowest tree replication in the Alpine

509 tree-ring chronology by Nicolussi et al. (2009) is observed around 6100 BCE, very close to the

$5108.2 \mathrm{ka}$ event. In a similar way, Helama et al. (2008) also suspect that the lack of subfossil trees in

511 Finnish Lapland was caused by the same climatic effect and that it would likely have decelerated

512 pine colonization in the region.

\section{5.2. The mid-Holocene}

514 About 8100 years ago, following the cold 8.2 ka event (Alley et al., 1997), tree establishment has

515 been recorded in various peatlands in northwestern Europe, namely in Ireland (Pilcher et al.,

516 1995; Torbenson et al., 2015), Germany (Leuschner et al., 2002; Eckstein et al., 2009; Achterberg

517 et al., 2015), Denmark (Christensen, 2007), and Sweden (Edvardsson et al., 2012b). These initial

518 pulses of tree establishment were followed by continuous and fluctuating mid-Holocene tree

519 colonization across northwest European peatlands (Fig. 8).

520 During the mid-Holocene, cross-dating between series from different regions yields

521 statistically significant results and points to striking similarities in annual growth and tree

522 population dynamics over substantial parts of northwestern Europe, especially for the period 5300

523 to 2500 BCE (7250-4550 BP; Fig. 6-7). The successful cross-dating between various sites,

524 sometimes separated by hundreds of kilometres, also indicates that similar year-by-year climate

525 variability has influenced environmental conditions at these peatlands, and thereby radial growth 
526 of trees (Pilcher et al., 1977, 1984; Leuschner et al., 2002; Eckstein et al., 2009; Edvardsson et

527 al., 2012a). Similarities in tree replication records on the other hand, show coinciding

528 regeneration and later life stages, whereas mean-age records indicate changes in the age structure

529 of tree populations. The German pines, for instance, were not randomly distributed over time.

530 Instead, woodland establishment and dying-off phases were periodic, as detected in pine

531 populations from 36 different German peatlands (Eckstein et al., 2009). Together, the significant

532 cross-dating statistics and similarities in tree population dynamics imply similar high- (i.e. annual

533 to decadal scale) and low-frequency variability (i.e. decadal to centennial scale) governed

534 hydroclimatic forcing mechanisms influencing peatland hydrology and associated tree growth

535 over a large geographic region (Fig. 6 and 10). Moreover, widespread colonization also points to

536 relatively dry and therefore favourable growth conditions for peatland trees, which is underlined

537 by the main woodland phases at German and Swedish peatlands between 5300 and 3700 BCE

538 (7250-5650 BP; Eckstein et al., 2009, 2011; Edvardsson et al., 2012a, b).

539 Pine records from the Alps show colonization at unusually high elevations (Tessier et al.,

540 1993) and strong replication (Nicolussi et al., 2009) during the same period. A combination of

541 high-altitude occurrence and an increased replication of subfossil pines is also evident in northern

542 Finland from 4200 to 2200 BCE (6150-4150 BP; Helama et al., 2004, 2010). The pine

543 colonisation of peatlands in northern Scotland occurred around 5000 years ago, and has been

544 interpreted as a regional phenomenon (Gear and Huntley, 1991; Charman, 1994; Daniell, 1997;

545 Huntley et al., 1997). By contrast, both oak and pine trees colonized Baltic peatlands during the

546 mid-Holocene (Pukienè, 2003; Vitas, 2010; Edvardsson et al., 2016a), and therefore add further

547 evidence of widespread impacts of favourable climatic conditions.

$548 \quad$ These favourable growth conditions for peatland trees during the mid-Holocene were 549 probably closely linked to a relatively warm and dry climate regime, which commonly is referred 
550 to as the Holocene Thermal Maximum (HTM; Seppä et al., 2005; Renssen et al., 2009). The onset

551 and termination of the HTM varies clearly between different geographical regions and studies,

552 but is generally dated to the period c. $6850-2450$ BCE (8000-4400 cal. BP) across northern

553 Europe (Jessen et al., 2005; Seppä et al., 2005; Renssen et al., 2009; De Jong et al., 2009). The

554 comparably high air temperatures and dry conditions in northwestern Europe were probably

555 caused by (i) an orbitally-forced increase in summer insolation, and (ii) a stronger meridional

556 overturning circulation and intensified northward ocean heat transport after the Laurentide Ice

557 Sheet had vanished (Snowball et al., 2004; Renssen et al., 2009; Wanner et al., 2011).

558 Temperature reconstructions based on stable isotopes from ice-cores as well as pollen data from

559 lake sediments and peat cores all point to summer temperatures which would have been

560 approximately $2-3^{\circ} \mathrm{C}$ above present values across most parts of northwestern Europe and

561 Scandinavia (Huntley and Prentice, 1988; Seppä et al., 2005; Brown et al., 2011; Helama et al.,

562 2012). At the same time, moisture records indicate a dry phase at about 5250 to $3750 \mathrm{BCE}$ (7200-

$5635700 \mathrm{BP}$; Wanner et al., 2011), which is confirmed indirectly by lake level proxies pointing to

564 generally low water levels (Digerfeldt, 1988; Hammarlund et al., 2003; Magny, 2004, 2013;

565 Sohar and Kalm, 2008).

566 The annual resolution and accurate dating of the tree-ring chronologies allow detailed

567 studies of rapid climatic events during the HTM, which may be missed in lower resolution

568 proxies. Several peaks in the Irish replication records have, for instance, been recorded about

$5696050,5350,4250$, and 1250 BCE $(8000,7300,6200$ and 3200 BP; Turney et al., 2006), and are

570 consistent with peaks and establishment phases detected in replication records from Germany, the

571 Netherlands, and Sweden (Fig. 10). Moreover, many dying-off phases described in the German

572 records (Leuschner et al., 2002; Eckstein et al., 2009; Bauerochse et al., 2015; Achterberg et al.,

573 2015) can be found in other records from northwestern Europe. For instance, the dying-off phase 
574 between 4600-4550 BCE (6550-6500 BP) described by Achterberg et al. (2015) is also visible in

575 the oak records from Germany and the Netherlands (Leuschner et al., 2002), as well as in the 576 Scottish (Bridge et al., 1990) and Swedish (Edvardsson et al., 2012a) pine records.

577 Towards the end of the HTM, shifts towards wetter conditions about $3250 \mathrm{BCE}$ and 2250 578 BCE (5200 and 4200 cal. BP) have been described in the literature (referred to as the 5.2 and 4.2 579 ka events; Roland et al., 2014, 2015). The 5.2 ka event (c. 3250 BCE) has been identified as a 580 coherent shift towards wetter conditions caused by prolonged positive North Atlantic Oscillation 581 conditions, and was found in stable isotope, testate amoebae, plant macrofossil, and humification 582 records from peatlands in Northern Ireland (Roland et al., 2015). Evidence for such a wet shift is 583 lacking in the Irish oak replication records, whereas a decrease in German peatland pines and a 584 dying-off phase in Lithuanian pines can be observed (Fig. 10). Moreover, a coincident phase of 585 lowered replication of subfossil pines is evident in northern Finland (Helama et al., 2004, 2010).

586 Several synchronous and massive dying-off phases can also be detected about 2500 BCE (4450 587 BP) in Scotland (Gear and Huntley, 1991; Charman, 1994; Daniell, 1997), Ireland (Pilcher et al., 588 1995), Great Britain (Lageard et al., 1999; Boswijk and Whitehouse, 2002), Germany (Eckstein 589 et al., 2011; Bauerochse et al., 2015), and Sweden (Edvardsson et al., 2014b), and thus point to a 590 spatially structured, regional environmental change. By way of example, the British peatland pine 591 chronologies from Garry Bog (2569 BCE; Pilcher et al., 1995), White Moss (2559 BCE; Lageard 592 et al., 1999), Thorne (2475 BCE; Boswijk, 1998), and Hatfield (2445 BCE; Boswijk and 593 Whitehouse, 2002) all terminate at $2507 \pm 62 \mathrm{BCE}(4456 \pm 62 \mathrm{BP})$.

\section{5.3. The late Holocene}

596 The unfavourable conditions recorded towards the very end of the HTM continued in a similar 597 manner between 2200 and 2160 BCE (4150-4110 BP; Fig. 10), and resulted in abrupt dying-off 
598 phases at various sites in northwestern Germany (Eckstein et al., 2010; Bauerochse et al., 2015),

599 the Netherlands (Leuschner et al., 2002), and Finland (Helama et al., 2004). The similarities

600 between continental and Irish mean-age records, which were present during the entire HTM, also

601 start to disappear at about $2000 \mathrm{BCE}$ (4000 BP; Leuschner et al., 2002). The effects of a large-

602 scale shift in climatic conditions are also obvious in northern Finland where the replication of the

603 subfossil pine chronology collapses around 2200-2000 BCE. Moreover, indications of pine

604 germination are clearly missing at the high elevation sites in Finland as of $2400 \mathrm{BCE}$ (4350 BP),

605 and are followed by a gradual decline in pine populations until $600 \mathrm{BCE}(2550 \mathrm{BP}$; Helama et al.,

606 2004). Since about 1500 BCE (3450 BP), following yet another dying-off phase recorded across

607 northwestern European peatlands, fewer dated peatland pines have been found in Germany

608 (Achterberg et al., 2015) and Ireland (Pilcher et al., 1973). Most of these observations can be

609 linked to the onset of a widespread climatic transition, sometimes referred to as the Neoglacial

610 phase (Nesje et al., 1991; Wanner et al., 2008).

611 The climatic change about 2250 BCE (4200 cal. BP and often refered to as the $4.2 \mathrm{ka}$

612 event; Roland et al., 2014) is evident at the hemispheric scale in numerous proxy records and was

613 most likely driven by changes in orbital insolation patterns (Bradley, 2003; Booth et al., 2005;

614 Morley et al., 2014), but changes in tree populations do not appear abruptly or synchronously

615 between different sites (Fig. 10). Instead, a multi-proxy study from Sweden points to a stepwise

616 transition phase dated to between c. 2650 and 1450 BCE (4600 and 3400 cal. BP; Jessen et al.,

617 2005). In a similar way, several dying-off events have been recorded among Swedish peatland

618 trees (Edvardsson, 2016), whereas a two-stage temperature decrease with an onset c. 3050-2550

619 BCE (5000-4500 cal. BP) and a termination c. 2350-1350 BCE (4300-3300 cal. BP) has been

620 described around the Baltic Sea (Borzenkova et al., 2015). Moreover, testate amoebae in Irish

621 peatlands do not provide any compelling evidence for a rapid transition about $2250 \mathrm{BCE}$ (4200 
622 cal. BP; Roland et al., 2014), whereas records from Great Britain and Denmark suggest a system

623 shift at about $2150 \mathrm{BCE}$ (4100 cal. BP; Mauquoy et al., 2008). These results show that the origin

624 and impact of the 4.2 ka event is spatially complex and was probably less marked than in low

625 latitudes, and may also explain why the drop in tree replication in Ireland and Sweden started 200

626 years later than in Germany and the Netherlands (Fig. 10). These results also confirm the need for

627 climate reconstructions with high spatio-temporal resolution to improve our understanding of

628 complex climate transitions. Pollen-based temperature reconstructions from Scandinavia show

629 that the annual mean temperature was reduced by almost $2{ }^{\circ} \mathrm{C}$ during this transition phase (Seppä

630 et al., 2005; Heikkila and Seppä, 2010), whereas lake-level reconstructions suggest wetter

631 conditions with rising lake levels between 3000 and 500 BCE (5000-2500 cal. BP; Digerfeldt,

632 1988; Magny, 2004, 2013; Sohar and Kalm, 2008). Indications of rising water levels after the

633 termination of the HTM also exist for northern Finland in the form of submerged pines with their

634 root systems anchored in the palaeo-shoreline, two meters below the current water level (Eronen

635 et al., 1999). The rising water tables and wetter peatland surface conditions are therefore also

636 believed to have caused widespread dying-off phases, leading to the termination of most Swedish

637 and German pine records at about 1100 BCE (3050 BP; Eckstein et al., 2011; Edvardsson, 2016).

638 Together, these observations indicate that the widespread transition towards wetter and colder

639 conditions continued for at least a millennium after the end of the HTM. These findings are also

640 confirmed by radiocarbon-dated recurrence surfaces detected in several Swedish peat sequences,

641 for which the wet shift is synchronous with the final dying-off phases in the German and Swedish

642 pine chronologies (Borgmark and Wastegård, 2008; Rundgren, 2008) and peat records from

643 northern Britain (Charman et al., 2006).

644 Although the period 2250-1100 BCE (4200-3050 BP) is in general associated with 645 increasingly wetter and colder conditions, some short and regional colonization events were still 
646 taking place. The German pine colonization phase at around 1900 BCE (3850 BP), described by

647 Bauerochse et al. (2015), is also visible in records from Sweden, the Netherlands, and Scotland 648 (Fig. 10). Over the last 3000 years, however, relatively few tree establishment phases have been 649 recorded in German and Irish peatlands, whereas trees appear to be close to absent at all known 650 Swedish sites (Fig. 10). Despite this fact, tree colonization has been recorded at peatlands in the 651 Netherlands (Sass-Klaassen and Hanraets, 2006), Poland (Barniak et al., 2014), Lithuania 652 (Pukienè, 1997; Edvardsson et al., 2016a), and in one of the few regions documented in North 653 America (Québec; Arseneault and Payette, 1997). With the exception of the Canadian records, 654 these phases are relatively short, which may also explain why only the Dutch chronologies have 655 been cross-dated successfully over long distances (Fig. 6-7). It is therefore difficult to judge to 656 what extent these tree colonization phases are related to site-specific variations or are linked to 657 regional climate dynamics.

658 About 850 BCE (2800 cal. BP), yet another shift towards cooler, wetter, and windier 659 conditions has been recorded in European peatlands (referred to as the 2.8 ka event; van Geel et 660 al., 1996, 2014; Mauquoy et al., 2008; Mellström et al., 2015). Observations made in peatlands 661 are confirmed by other proxy records, which suggest rising lake levels (Magny, 2004, 2013) and 662 more drift ice in the North Atlantic (Bond et al., 1997). The nature and causes of this cold and 663 wet event have been subject to debate, but the shift broadly coincides with an increase of the 664 atmospheric ${ }^{14} \mathrm{C}$ concentration due to reduced solar activity (Kilian et al., 1995; Swindles et al., 665 2013; Mellström et al., 2015). The Irish replication and mean-age records indicate dying-off 666 phases or generation shifts, whereas the German and Dutch series point to a decline in replication 667 records (Fig. 10). A dying-off phase about $850 \mathrm{BCE}$ has also been detected in the Polish tree-ring 668 chronologies (Barniak et al., 2014). Despite the general absence of dated peatland pine 669 chronologies from Sweden, macrofossil analysis from a southwest Swedish peat bog shows that 
670 pine must have been present locally at the site prior to $910 \mathrm{BCE}$ (2860 cal. BP), but was absent 671 after 740 BCE (2690 cal. BP; Mellström et al., 2015). Gaps also exist in Lithuanian (Edvardsson 672 et al., 2016a) and Canadian (Arseneault and Payette, 1997) tree records during the same period, 673 which may strengthen the hypothesis that the $2.8 \mathrm{ka}$ event did indeed significantly influence large 674 parts of the northern Hemisphere.

675 Between c. $500 \mathrm{BCE}$ and $\mathrm{CE} 300$ (2500 and $1600 \mathrm{BP})$, tree replication records from 676 Ireland, Germany, and the Netherlands again show some tree colonization phases, but of minor 677 importance (Fig. 10). These colonizations coincide with somewhat warmer and drier climatic 678 conditions during the period often referred to as the Roman Warm Period (RWP; Seneviratne et 679 al., 2010; Büntgen et al., 2011). Partial agreements between the Irish and continental mean-age 680 records presumably indicate changes between relatively similar and diverse forcing mechanisms 681 between the two regions over the period (Leuschner et al., 2002). In the Netherlands, a shift in 682 tree population dynamics with establishment of both oak and ash trees has been recorded as late 683 as AD 300 (1600 cal. BP) followed by striking changes in site hydrology and a dying-off phase at 684 about AD 530 (Sass-Klaassen and Hanraets, 2006).

685 Dying-off phases recorded at several peatlands in Lithuania (Pukienè, 1997; Edvardsson 686 et al., 2016a), by contrast, coincide with the well-known cooling at about 300-600 AD (1650$6871350 \mathrm{BP}$ ), which is commonly referred to as the Dark Age or Migration Period (Wanner et al., 688 2011). At about AD 800 (1200 cal. BP), massive tree establishment has been recorded in 689 Lithuanian peatlands (Pukienè, 1997; Edvardsson et al., 2016a) and at the same time, peat records 690 from both Great Britain and Denmark point to a dry phase (Mauquoy et al., 2008). These changes 691 coincide with the onset of the Medieval Warm Period (MWP) and indicate yet another change 692 towards drier conditions in peatlands. Furthermore, Arseneault and Payette (1997) have reported 
693 strong radial tree growth over the corresponding period, which indicates relatively favourable

694 conditions for tree growth at Canadian peatlands as well.

695 By contrast, an almost complete absence of subfossil peatland trees has been recorded 696 during the Little Ice Age (LIA; AD 1350-1850), which clearly indicates colder and moister 697 conditions compared to the preceding periods (Wanner et al., 2008) and a widespread lack of tree 698 establishment at peatland sites (Fig. 10). Widespread wet shifts have also been reported in 699 European peat stratigraphic records at about CE 1350 and 1600 (600 and $350 \mathrm{cal}$. BP; Mauquoy 700 et al., 2008). Apparently these conditions generated growth conditions that were too harsh for 701 peatland trees as the final dying-off phases, recorded at about AD 1400 (550 cal. BP), coincide 702 with a shift towards colder (Wanner et al., 2011) and wetter (Charman et al., 2006) climatic 703 conditions. These observations are also supported by the fact that finding recent peatland pines 704 older than 200 years has proven very difficult (Linderholm et al., 2002; Cedro and Lamentowicz, 705 2011; Edvardsson et al., 2015a), confirming the likely absence of peatland trees during the LIA.

706 As the LIA came to an end, widespread pine colonization occurred in peatlands across Estonia 707 (Smiljanić et al., 2014), Lithuania (Edvardsson et al., 2015a), Poland (Cedro and Lamentowicz, 708 2011), and Sweden (Linderholm and Leine, 2004; Edvardsson and Hansson, 2015). Observed tree 709 establishment in recent periods is likely to result from a combination of climatic and land-use 710 changes. Nevertheless, changing climatic conditions over the twentieth century have, at least in 711 some cases, been regarded to be the most important driver of increasing tree establishment rates 712 (Edvardsson et al., 2015b).

713

714

\section{6. Target areas for future research}


717 There is still a need for improved understanding of the relations between peatland tree growth,

718 moisture variability, and climate dynamics, to enable more robust hydrology and climate

719 interpretation from peatland tree-ring, replication, and mean-age records. For example, there is a

720 clear need for new methods to isolate the temperature and precipitation signals in tree-growth

721 patterns. Here, we address several suggestions for future studies, which will help to advance our

722 understanding of peatland tree-growth variability, as well as of the connections between tree

723 growth, peatland hydrology, and climate dynamics. We also discuss potential new research fields

724 using subfossil peatland trees.

725

$726 \quad 6.1$. Isolating and amplifying the climate signal

727

728 6.1.1. Long-term reconstructions using multiple proxy records

729 To understand the basic functions of peatland tree growth and colonization, tree growth and

730 population dynamics data need to be compared and coupled with climate-moisture proxies.

731 Studies using peat stratigraphic records have been carried out to detect large-scale hydrological

732 shifts to put the subfossil tree record into a long-term environmental context (Gunnarson et al.,

733 2003; Eckstein et al., 2010, 2011; Edvardsson et al., 2012b, 2014b). To advance these

734 interpretations further, comparisons using pollen (Gear and Huntley, 1991; Eckstein et al., 2010,

735 2011; Edvardsson et al., 2014b), plant macrofossils (Edvardsson et al., 2014b), and peat

736 humification (Edvardsson et al., 2012b) have been undertaken. The disadvantage of such proxy

737 records is their multi-annual temporal resolution and lower temporal precision that radiocarbon

738 ages offer compared to trees. To improve comparative long-term studies further, proxy records of

739 higher, preferably annual resolution are required. Such records can sometimes be obtained from

740 laminated lake sediments (Veski et al., 2004; Tylmann et al., 2013), ice cores (Vinther et al., 
741 2006), speleothems (Labuhn et al., 2015), corals (Zinke et al., 2014), and highly resolved peat

742 stratigraphic records (Gear and Huntley, 1991; Amesbury et al., 2012). The disadvantage of most

743 annually resolved data sources is that they do not record peat hydrological changes directly,

744 although they do provide an independent record of hydroclimate variability against which to test 745 the dendroecological time series.

$746 \quad$ Further in-depth comparison between multi-millennial tree-ring chronologies representing

747 different environments and soil types is another approach that is generating valuable

748 paleoenvironmental information. Such comparative studies have been performed using living

749 pine trees (Linderholm et al., 2002; Cedro and Lamentowicz, 2011; Edvardsson et al., 2015a), but

750 Bauerochse et al. (2015) recently started to compare subfossil Hohenheim oaks conserved in river

751 sediments and gravel pits (Spurk et al., 2002; Friedrich et al., 2004) to peatland oaks from Lower

752 Saxony (Leuschner et al., 2002). Although comparisons showed promising potential, it would be

753 premature to draw any conclusions as the focus was on a relatively short period of the past (2500-

$7542000 \mathrm{BCE}$ or $4450-3950 \mathrm{BP})$. We call for further comparisons of continuous material such as the

755 German oak chronologies or attempts to correlate Scandinavian peatland tree-ring reconstructions

756 with the Torneträsk (Grudd et al., 2002) or Jämtland (Gunnarson et al., 2003) chronologies, as

757 moisture and temperature sensitive records would then be compared over multi-millennial time

758 scales.

\subsubsection{Assessment of hydroclimate and tree growth relationships}

761 Dendroclimatic studies using living peatland trees and meteorological data represent yet another

762 field, which has remained largely underexplored (Cedro and Lamentowicz, 2011; Smiljanić et al.,

763 2014), but which has potential to increase our understanding of relations between peatland tree

764 growth and climate variables. In addition, previous work may not have been conclusive due to 
765 hydrological lag effects and poorly understood feedback mechanisms in peatlands (Linderholm et 766 al., 2002; Edvardsson et al., 2015a; Edvardsson and Hansson, 2015). Most studies have 767 consistently reported a negative correlation between annual tree growth and precipitation records, 768 yet correlation statistics have mostly been insignificant (Fig. 8). The use of continuous growth 769 monitoring devices (such as manual or automated dendrometers), micro-meteorological stations 770 and local hydrological stations (i.e. piezometers) could be a valuable way to address relations 771 between meteorological events, water-table fluctuations, and tree growth in more detail and with 772 fewer uncertainties. The combination of such monitoring records may also provide key insights 773 into the hydrological functioning of peatland ecosystems, and especially into lag effects and their 774 impact on tree growth. This hypothesis of a lag effect is supported by unpublished data from 775 Čepkeliai peatland (southeastern Lithuania) where TRW records (AD 1848-2014) have been 776 correlated with hydrological and meteorological time series from the nearby Varena station (AD 777 1951-2013). At Čepkeliai, bootstrap correlation functions between the TRW chronology and 778 monthly temperature and precipitation only show significant correlation $(r=0.25, p<0.05)$ with 779 previous October precipitation (Fig. 8). At the same time, comparison between the TRW 780 chronology and a much shorter, but local peatland water-table record (AD 2001-2014) shows 781 significantly stronger negative correlation ( $\mathrm{r}=-0.67$, $\mathrm{p}<0.05$; Fig. 11). Although the water-table 782 record only covers the last 13 years, these first correlation tests point to the potential of a 783 combined approach. At the same time, they suggest that peatland tree growth might be a valuable 784 direct measurement of moisture changes in peatlands, but a poorer proxy for direct precipitation 785 reconstructions. As long instrumental hydrological records do not exist for peatlands, we suggest 786 progress is made by: (i) testing for correlations between TRW series and hydrometeorological 787 variables, such as the ratio of actual to potential evapotranspiration (AET/PET) computed from 788 temperature and precipitation values; (ii) using tree-growth process models driven by climate and 
789 other environmental factors (such as nutrient availability and soil moisture) as they might allow

790 better understanding of tree functioning and the effect which the interaction of different

791 environmental forcings has on tree growth (see Guiot et al., 2014 for a review); and (iii) deriving

792 longer-term water-table fluctuations series from locally-calibrated, process-based hydrological

793 models (see Gong et al., 2012 for a review on the topic) driven by local climatic parameters

794 (temperature, precipitation).

795

\subsubsection{Stationarity in tree growth-climate relationships?}

797 Dendroclimatology commonly assumes stationarity in the relationship between tree growth and

798 climate, and that trees are reacting to environmental changes in the same manner at present as

799 they have in the past (uniformitarian principle; Fritts, 1976). This principle has, however, been

800 challenged due to the divergence (Briffa et al., 1998a, b; Wilmking et al., 2005; D’Arrigo et al.,

801 2008) of tree growth at some Nordic sites which used to be temperature-limited in the past, but

802 show a weakening in their mean temperature response in recent decades as a result of global

803 warming. One should thus also assume changes in tree growth-climate relationships at longer

804 timescales as both climate and peatlands have undergone substantial changes over the course of

805 the Holocene. As a consequence, results and conclusions drawn from living material may not

806 therefore be directly transferable to subfossil trees. Trees in Swedish peatlands were shown to be

807 smaller and less long-lived under current conditions (average diameter $16 \mathrm{~cm}$, age $105 \mathrm{yrs}$.) as

808 compared to the mid-Holocene when the same species produced significantly larger and older

809 trees (average diameter 25-30 cm and age 175 yrs.; Lindbladh et al., 2013). These differences can

810 be explained by more favourable climatic conditions and shallower peatlands in earlier periods,

811 but that may not be the only explanation. Further studies should specifically look into age, size, 812 and radial growth relations over various periods of the Holocene. Moreover, the development of 
813 dedicated standardisation techniques, designed to remove internal, non-climatic growth trends in

814 ring-width series, with an aim to account for tree productivity-related biases needs further

815 evaluation. For example, the Signal-Free Regional Chronology Standardisation (Melvin and

816 Briffa, 2014) approach should be preferred for reconstructions if they contain both living and

817 subfossil peatland trees.

818

819 6.1.4. What does tree replication mean?

820 Tree replication data are often used as a climate proxy, but this has recently caused debate about

821 its value for climate inferences and on ways to interpret such records (Charman, 2010; Swindles

822 and Plunkett, 2010; Swindles et al., 2013; McGeever and Mitchell, 2015). Looking at the 2500

823 BCE-CE 1600 period, Swindles and Plunkett (2010) reported a lack of consistent relationship

824 between the Irish oak replication (Turney et al., 2005) and palaeohydrological records (Mauquoy

825 et al., 2008; Magny, 2004, 2013), changing solar activity (Hu et al., 2003; Muscheler et al.,

826 2005), or stacked drift ice records (Bond et al., 2001). However, Charman (2010) successfully

827 reconciled the Irish bog oak record with a large-scale compilation of peatland water table

828 reconstruction and other evidence from northern Britain, and showed the commencement of

829 declines in Irish oak populations were coincident with increased surface wetness in northern

830 British peatlands. This suggests that it is the direction of change in the population that is

831 sensitive to surface wetness, rather than the absolute numbers of trees in the record at any one

832 time. Disagreement between records in Swindles and Plunkett (2010) could be a consequence of

833 the mid-Holocene transition towards moister conditions about 2500 BCE (4450 BP; Wanner et

834 al., 2008), which caused divergent reactions between Irish and continental oak records

835 (Leuschner et al., 2002). It may also be a function of comparison with atypical surface wetness

836 records and the relatively small number of records after c. 2200 years ago (Pilcher et al., 1996). 
838 pines dated by radiocarbon, and suggested that factors other than climate, such as the availability

839 of pine seeds and peatland surface area, may have influenced the presence of trees at Irish

840 peatlands and that this limitation might have disrupted the climate signal of the record during

841 certain periods. Despite this possible shortcoming, their pine record nevertheless shows a

842 significant peak during the late part of the HTM, a decline during the late-Holocene transition, an

843 absence of material during the 8.2 and 2.8 ka events, as well as during the LIA (Fig. 10).

844 Whilst there is a sound theoretical underpinning and increasing evidence for interpreting

845 tree records in terms of palaeoclimate, we acknowledge that tree replication will be influenced by

846 factors other than climatic wetness changes (Swindles and Plunkett, 2010; Swindles et al., 2013;

847 McGeever and Mitchell, 2015), such as natural succession and the transformation of a peatland

848 from a wetland to a raised bog (Fig. 2). Moreover, tree replication in different geographical

849 settings may not reflect the same environmental changes. Competition between tree species

850 colonizing peatlands in parallel is another possible factor influencing tree replication. In-depth

851 comparative studies between overlapping records from in-situ pine and oak trees from common

852 study sites may generate valuable information on competition between species, habitat

853 preferences and tree population dynamics. Furthermore, research on processes governing

854 peatland tree colonization in different geographical regions might help us to understand if

855 establishment and dying-off phases reflect similar environmental processes or if local controls are 856 more important.

\section{$858 \quad \mathbf{6 . 2}$ New study areas and research fields}


861 This review provides a literature-based overview of geographical areas for which tree-ring 862 analyses have been performed with subfossil peatland trees (Fig. 1 and Table 1). The distribution

863 of peatland regions in the Northern Hemisphere (Fig. 1) also enables us to identify new potential

864 study areas, at least for living peatland trees. In that sense, we hypothesize that Québec, Ontario,

865 and the Northern regions of Canada in more general terms, Southern Siberia (Russia), as well as

866 the Baltic countries clearly represent areas in which the potential of peatland dendrochronology

867 has been underutilized in the past, as shown by a series of very recent studies on Lithuanian

868 (Edvardsson et al., 2016b), Polish (Krąpiec and Szychowska-Krąpiec, 2016), and Romainian

869 (Árvai et al., 2016) peatland trees. Peat mining areas where there are likely to be exposed

870 subfossil trees can be detected easily on aerial photographs and satellite imagery. In some cases,

871 large wood deposits can also be observed on aerial photos of peat mining areas, but contacts with

872 peat mining companies are probably the best way of identifying which sites also have subfossil

873 wood remains.

874

875 6.2.2. Potential new indicators for detection of moisture changes

876 Stable isotopes in tree rings have proven to provide palaeoclimatic information with annual 877 resolution (see Loader and Switsur, 1996; McCarroll and Loader, 2004). Despite this, only two

878 studies exploring the potential of stable carbon $\left(\delta^{13} \mathrm{C}\right)$ and oxygen $\left(\delta^{18} \mathrm{O}\right)$ isotopes have been 879 performed so far with subfossil peatland tree material (Sass-Klaassen et al., 2005; Edvardsson et 880 al., 2014a). When considered together, these isotopes have been shown to be sensitive to the 881 variability in growing season moisture regimes experienced by trees. Based on the correlation 882 analysis between TRW and isotope series, Edvardsson et al (2014a) demonstrated a three-year lag 883 between a decline in $\delta^{13} \mathrm{C}$ and $\delta^{18} \mathrm{O}$ values in trees and the corresponding tree-ring response, 884 possibly reflecting a relatively slow rise in local water table in response to wetter climate. Despite 
885 the fact that isotopic records generate much additional information compared to TRW records 886 alone, no further attempts have been performed to date, possibly as these methods are still 887 expensive and time consuming.

888 Despite the fact that roots will be the first to experience any changes in water-table 889 fluctuations, root morphology has been used only rarely to detect possible water table changes in 890 peatland ecosystems (Lageard et al., 1995; Eckstein et al., 2010). For example, a substantial water 891 table lowering may cause the formation of adventitous roots (Stoffel and Bollschweiler, 2008). 892 Dendrochronological dating of roots (Stoffel et al., 2013), in combination with field 893 measurements of their depth and morphological features, may generate detailed information 894 about the timing and magnitude of hydrological shifts (Eckstein et al., 2010). Such information 895 cannot be obtained without a detailed assessment of root morphology in the field and the 896 sampling of second-generation, adventitious roots. We therefore recommend systematic field 897 measurements and sampling of adventitous roots to test their response to a decline in water table, 898 and to evaluate whether this can lead to instability of moist surfaces and subsequent formation of 899 reaction wood (Stoffel and Bollschweiler, 2008) in trees (Fig. 5).

900 Another important aspect of peatland ecosystems and environmental changes is their 901 response to fire, which can be studied through absolutely dated fire scars in subfossil or living 902 trees (Arseneault and Payette, 1997; Lageard et al., 2000; Eckstein et al., 2009; Edvardsson et al., 903 2012a). The age and frequency of fires may not be sufficient to estimate the loss of burned carbon 904 from peatlands, but periods showing an increase in fire activity may be indicative of phases with 905 relatively dry surface conditions. The fire scar records cannot be compared yet, as they do not 906 originate from continuous records and do not overlap sufficiently in time. Further studies are 907 therefore required to evaluate if increased fire frequency in tree-ring records does indeed 908 correspond to periods of relatively dry peatland surface conditions. In addition, fire-scar records 
909 can be compared to existing charcoal records, which often represent continuous records and thus

910 can provide clear evidence of fire frequency and intensity at local to regional scale (Patterson and

911 Backman, 1988). If combined, the two approaches clearly have the potential to generate long-

912 term data from charcoal and more detailed (i.e. annual to intra-annual) records for those periods

913 for which tree-ring data are available.

914 The anaerobic conditions in saturated peat soils generate exceptional preservation

915 conditions for organic material (Fig. 4). Rapid wet shifts usually cause increased vertical rates of

916 peat growth, which can be identified in the form of recurrence surfaces in stratigraphic records

917 (Granlund, 1932; Rundgren, 2008). The same environmental changes will also result in quick

918 burial of dead peatland trees, and thereby improved preservation conditions for woody material

919 (Kokkonen, 1923; Leuschner et al., 2007). The degree of post-mortem degradation and stem

920 height can therefore be used as indicators of the moisture status following tree death. Excellent

921 preservation and conserved stem bark over distances greater than $30 \mathrm{~cm}$ above root level would

922 indicate fast burial due to moist conditions and rapidly growing peat, whereas conical and eroded

923 stumps lacking bark have been shown to be characteristic of slow burial and slow vertical peat

924 growth (Eckstein et al., 2009; Edvardsson et al., 2012a). A guide or strategy for a degradation

925 index for in-situ stumps would therefore be useful and would facilitate evaluation of peat

926 moisture conditions following dying-off phases.

927 By capitalizing on variable phenologies and tree growth responses to water-table

928 fluctuations, multispecies reconstructions may provide significantly more information about past

929 hydroclimatic variability than what we have today. In this context, Picea, Fraxinus, Alnus, Taxus

930 and Betula have repeatedly been observed in peat mining areas (Godwin, 1975; Arseneault and

931 Payette, 1997; Vitas, 2010; Edvardsson et al., 2014b), but to date, they have only rarely been used

932 as an additional source of information. Of course, the potential of developing multi-millennial 
933 chronologies will be limited for many of these species, but they may provide additional

934 contextual evidence for the longer chronologies (Sass-Klaassen and Hanraets, 2006; Edvardsson

935 et al., 2014b).

936

937 6.2.3. Carbon storage capacity

938 The interaction between tree colonization, peatland surface moisture, and net carbon

939 sequestration is complex (Limpens et al., 2014a; Holmgren et al., 2015). Some authors have

940 suggested that peatlands may turn from carbon sinks into carbon sources during dry periods

941 (MacDonald et al., 2006; Yu et al., 2010; Limpens et al., 2011), and that dry surface conditions

942 will favour tree growth, tree colonization and increased standing biomass in peatland

943 environments (Freléchoux et al., 2000; Limpens et al., 2014a; Edvardsson et al., 2015b). Phases

944 with widespread peatland tree colonization may thus also represent periods of less important

945 peatland carbon accumulation, or even point to phases during which peatlands were indeed acting

946 as carbon sources. Although tree colonization is likely to increase productivity and litter input,

947 which may in turn increase peat accumulation rates, total peat accumulation and carbon

948 sequestration is believed to be reduced as soon as drier conditions start to turn open moss-

949 dominated peatlands into tree-covered conditions (Limpens et al., 2014a; Holmgren et al., 2015).

950 Further studies are, however, needed on the effects of tree colonization on the drying of

951 peatland surfaces due to increased water loss through tree evapotranspiration, and to determine

952 whether such scenarios have the potential to transform peatlands from net carbon sinks into

953 sources. The effects that tree stand density have on water loss are important and will have

954 implications for the structure and functioning of peatlands, especially as the relation between

955 evapotranspiration and tree stand density is non-linear (Limpens et al., 2014a). Systematic 956 measurements of surface peat moisture, water-table depths, and carbon fluxes to the atmosphere 
957 between tree-covered and open peatland areas may give a first indication of the drying effect of

958 trees. Such studies would need to be performed on natural and managed peatlands representing

959 different geographical regions and to look into feedbacks and lag effects between climate,

960 peatland hydrology, and tree growth. To solve some of these remaining issues, we call for

961 continuous monitoring - over at least some years to decades - of; (i) tree growth in peatlands

962 with dendrometers, (ii) water table fluctuations, and (iii) carbon fluxes. To assess the overall

963 carbon balance in peatlands fully, more sophisticated multi-scale approaches will however, be

964 needed, such as those developed by e.g., Fox et al. (2008) and Hartley et al. (2015), as these will

965 also take account of the gaseous carbon components (i.e. $\mathrm{CO}_{2}$ and $\mathrm{CH}_{4}$ fluxes) as well as of the

966 dissolved carbon components (i.e. DOC, DIC, and POC). Moreover, such a monitoring setup

967 would enable calibration and validation of dynamic vegetation and ecosystem models such as the

968 modified version of LPJ-GUESS (Lund-Potsdam-Jena General Ecosystem Simulator; Smith et

969 al., 2014) named LPJ-GUESS Why-Me (Wetland Hydrology and Methane, Wania et al., 2009,

970 2010) and other models that are now including peatland carbon accumulation and methane

971 emission processes. Given the likelihood of significant shifts in treeline distribution across the

972 boreal and arctic, improved parameterisation of the interactions between peatland tree growth,

973 hydrology and carbon cycling is essential. A better understanding of the impact climate change

974 may have on tree cover, moisture variability and associated changes in the carbon balance in

975 peatland ecosystems, will advance the possibilities for reliable predictions for future climate 976 change.

977

978

979 7. Conclusions

980 
981 Contemporary ecosystems can be used to study present-day conditions and to estimate historical 982 environmental changes, typically over timescales of decades. Palaeoecological techniques 983 provide much greater temporal depth (Jeffers et al., 2015), and allow assessments over periods 984 that have experienced significantly different climatic conditions compared to the present day. 985 Despite significant potential, subfossil wood has been identified as one of the most underutilized 986 sources of information in palaeoecology and forest conservation research (Lindbladh et al., 2013).

987 In this review, we have illustrated the origins and recent developments in the field of tree-ring 988 research in peatland environments, compiled the major datasets from Europe and North America, 989 but also identified thematic and geographic areas for which knowledge is still fragmentary. We 990 call for further studies using subfossil peatland trees for detailed reconstructions of long-term 991 hydroclimate dynamics and palaeoecological changes. Beyond palaeoclimate reconstruction and 992 palaeoenvironmental understanding, we expect such data to be important in conservation 993 planning and to determine restoration baselines for peatland management.

994 For more than a century, subfossil peatland trees have been used as a proxy record for 995 environmental changes (Dau 1829; Vaupell 1851; Nielsen and Helama, 2012). Over the last 996 decades, however, numerous studies have started to use the information contained in the annually 997 resolved tree-ring records in more detail to assess climatic changes during the Holocene in the 998 British Isles, Scandinavia, and throughout Central Europe (Table 1, Fig. 1). Through the 999 comparison between tree replication records, tree-ring width chronologies, climate and moisture 1000 proxies (i.e. ice cores, sediment records, pollen), as well as meteorological data, detection of 1001 climatic signals in peatland trees has been improved substantially. We conclude that:

1002 (1) Our current knowledge of the effects of (hydro-)climatic changes and anthropogenic 1003 activities on tree growth in peatland ecosystems is mainly based on ecophysiological, 1004 dendroclimatic, and dendroecological perspectives; 
(2) A majority of existing studies shows that excess moisture is a growth-limiting factor for peatland trees. Proxy records developed from subfossil peatland trees therefore have the potential to help in the reconstruction of (i) local water-table fluctuations, and (ii) regional hydroclimate dynamics. Annual tree-growth patterns can be used to assess changes at annual to decadal scales, whereas tree population dynamics reflect changes at decadal to centennial time scales;

(3) Substantial work has been performed using subfossil trees from Germany, Great Britain, Ireland, the Netherlands, and parts of Scandinavia, whereas the vast majority of Canada, Russia, and the Baltic countries have significant under-exploited potential for the development of geographically widespread records;

(4) Our data compilation showing temporal distribution of subfossil peatland forests confirms that relatively warm and dry periods - such as the HTM - offered conditions which were favourable for tree growth in peatlands and thereby allowed widespread tree colonization, whereas transitions towards moister and colder conditions (e.g., the mid-late Holocene transition and the LIA) are associated with widespread dying-off phases and/or depressed annual tree growth;

(5) Further studies using e.g., stable isotopes, dendroclimatology, and field monitoring are critical to increase our knowledge about tree growth responses associated with hydroclimate changes, including understanding of hydrological lag and feedback effects detectable from lagging tree growth responses to climate on peatlands.

\section{Acknowledgment}

This study is part of the project CLIMPEAT (Climate change in peatlands: Holocene record, recent trends and related impacts on biodiversity and sequestered carbon) and funded by the 
1029 Lithuanian-Swiss cooperation program to reduce economic and social disparities within the 1030 enlarged European Union (agreement No CH- 3-SMM-01/05).

1031

1032 References

1033 Aaby, B., 1976. Cyclic climatic variations in climate over past 5,500 yr reflected in raised bogs. $1034 \quad$ Nature 263, 281-284.

1035 Achterberg, I., Bauerochse, A., Giesecke, T., Metzler, A., Leuschner, H.H., 2015. 1036 Contemporaneousness of trackway construction and environmental change: a 1037 dendrochronological study in Northwest-German mire. Interdisciplinaria Archaeologica $1038 \quad$ Nat. Sci. Archaeol. 6, 19-29.

1039 Achterberg, I., Frechen, M., Bauerochse, A., Eckstein, J., Leuschner, H.H., 2016. The Göttingen 1040 tree-ring chronologies of peat-preserved oaks and pines from Northwest Germany. Z. 1041 Deutsch. Gesellsch. Geowiss., doi: http://dx.doi.org/10.1127/zdgg/2016/0042

1042 Alley, R.B., Mayewski, P.A., Sowers, T., Stuiver, M., Taylor, K.C., Clark, P.U., 1997. Holocene 1043 climate instability: a prominent widespread event 8200 yr ago. Geology 25, 483-486.

1044 Almendinger, J.C., Almendinger, J.E., Glaser, P.H., 1986. Topographic fluctuations across a 1045 spring fen and raised bog in the Lost River Peatland, Northern Minnesota. J. Ecol. 74, 3931046401.

1047 Amesbury, M.J., Barber, K.E., Hughes, P.D.M., 2012. Can rapidly accumulating Holocene peat 1048 profiles provide sub-decadal resolution proxy climate data? J. Quat. Sci. 27, 757-770.

1049 Arseneault, D., Payette, S. 1997. Reconstruction of millennial forest dynamics from tree remains $1050 \quad$ in a subarctic tree line peatland. Ecology $78,1873-1883$. 
1051 Árvai, M., Popa, I., Mîndrescu, M., Nagy, B., Kern, Z., 2016. Dendrochronology and radiocarbon 1052 dating of subfossil conifer logs from a peat bog, Maramureş Mts, Romania. Quat. Int. 1053 doi:10.1016/j.quaint.2015.11.066

1054 Baillie, M.G.L., 1973. A recently developed Irish tree-ring chronology. Tree-Ring Bulletin 33, $1055 \quad 15-28$.

1056 Baillie, M.G.L., 1977. The Belfast oak chronology to A.D. 1001. Tree-Ring Bulletin 37, 1-13.

1057 Baillie, D.M., Pilcher, J.R., 1973. A simple cross-dating program for Tree-Ring Research. Tree$1058 \quad$ Ring Bulletin 33, 7-14.

1059 Baillie, M.G.L., Pilcher, J.R., Pearson, G.W. 1983. Dendrochronology at Belfast as a background 1060 to high-precision calibration. Radiocarbon 25, 171-178.

1061 Baillie, M.G.L., Brown, D.M., 1988. An overview of oak chronologies. in: Slates, E.A., Tate, 1062 J.O., (Eds.), Science and Archaeology, Glasgow 1987, Brit. Arch. Rep. Brit. 196, pp. 543$1063 \quad 548$

1064 Baillie, M.G.L., 1995. A Slice Through Time: Dendrochronology and Precision Dating. B.T. 289 1065 Batsford, London.

1066 Barber, K.E., 1981. Peat stratigraphy and climatic change: a palaeoecological test of the theory of 1067 cyclic peat bog regeneration. Balkema, Rotterdam.

1068 Barber, K.E., Chambers, F.M., Maddy, D., Stoneman, R., Brew, J.S., 1994. A sensitive high1069 resolution record of late Holocene climatic change from a raised bog in northern England. $1070 \quad$ Holocene 4, 198-205.

1071 Barber, K.E., Chambers, F., Maddy, D., 2003. Holocene palaeoclimates from peat stratigraphy: 1072 macrofossil proxy climate records from three oceanic raised bogs in England and Ireland.

1073 Quat. Sci. Rev. 22, 521-539. 
1074 Barniak, J., Krapiec, M., Jurys, L., 2014. Sub-fossil wood from the Rucianka raised bog (NE 1075 Poland) as an indicator of climatic changes in the first millennium BC. Geochronometria $41,104-110$.

1077

1078

1079

1080

1081

1082

1083

1084

1085

1086

1087

1088

1089

1090

1091

1092

1093

1094

1095

1096

Bauerochse, A., Achterberg, I., Leuschner, H.H., 2015. Evidence for climate change between $2200 \mathrm{BC}$ and $2160 \mathrm{BC}$ derived from subfossil bog and riverine trees from Germany. Tagungen des Landesmuseums für Vorgeschichte Halle 13, 1-7.

Becker, B., 1983. The long-term radiocatbon trend of the absolute german oak tree-ring chronology, 2800 to 800 BC. Radiocarbon 25, 197-203.

Becker, B., Schirmer, W., 1977. Palaeoecological study on the Holocene valley development of the River Main, southern Germany. Boreas 6, 303-321.

Birks, H.J.B., Seppä, H., 2010. Late-Quaternary palaeoclimatic research in Fennoscandia - A historical review. Boreas 39, 655-673.

Birks, H.H., Aarnes, I., Bjune, A.E., Brooks, S.J., Bakke, J., Kühl, N., Birks, H.J.B., 2014. Lateglacial and early-Holocene climate variability reconstructed from multi-proxy records on Andøya, northern Norway. Quat. Sci. Rev. 89, 108-122.

Blackford, J.J., Chambers F.M., 1991. Proxy records of climate from blanket mires: evidence for a Dark Age (1400 BP) climatic deterioration in the British Isles. Holocene 1, 53-67.

Blanchet, G., Bragazza, L., Stoffel, M., Guillet, S., Edvardsson, J., Corona, C., Calliari, B., 2016. Impacts of regional hydroclimate fluctuations on radial growth of Siberian and Scots pine in the Mukhrino mire (Western Siberia). Sci. Total. Environ. doi: 10.1016/j.scitotenv.2016.06.225

Blytt, A., 1876. Essay on the immigration of the Norwegian flora during alternating rainy and dry periods. Cammermeye, Christiana. 
1097 Bond, G., Showers, W., Cheseby, M., Lotti, R., Almasi, P, deMenocal, P., Priore, P., Cullen, H., 1098 Hajdas, I., Bonani, G., 1997. A pervasive millennial-scale cycle in North Atlantic Holocene 1099 and glacial climates. Science 278, 1257-1266.

1100 Bond, G., Kromer, B., Beer, J., Muscheler, R., Evans, M.N., Showers, W., Hoffmann, S., Lotti1101 Bond, R., Hajdas, I., Bonani, G., 2001. Persistent solar influence on North Atlantic climate 1102 during the Holocene. Science 278, 1257-1266.

1103 Boggie, R. 1972. Effect of water-table height on root development of Pinus contorta on deep peat 1104 in Scotland. Oikos 23, 304-312.

1105 Booth, R.K., Jackson, S.T., Forman, S.L., Kutzbach, J.E., Bettis III, E.A., Kreig, J., Wright, D.K., 1106 2005. A severe centennial-scale drought in mid-continental North America 4200 years ago and apparent global linkages. Holocene 15, 321-328.

1108 Borgmark, A., Wastegård, S., 2008. Regional and local patterns of peat humification in three 1109 raised peat bogs in Värmland, south-central Sweden. GFF 130, 161-176.

1110 Boswijk, G. 1998. A dendrochronological study of oak and pine from the Humberhead Levels, 1111 eastern England. PhD thesis, University of Shefield.

1112 Boswijk, G., Whitehouse, N.J., 2002. Pinus and Prostomis: a dendrochronological and 1113 palaeoentomological study of a mid-Holocene woodland in eastern England. Holocene 12, $1114 \quad 585-596$.

1115 Borzenkova, I., Zorita, E., Borisova, O., Kalniņa, L., Kisielienè, D., Koff, T., Kuznetsov, D., 1116 Lemdahl, G., Sapelko, T., Stančikaitè, M., Subetto, D., 2015. Climate Change during the 1117 Holocene (Past 12,000 Years), in: BACC II author team. 2015. Second assessment of 1118 climate change for the Baltic Sea basin. Regional climate studies. Berlin: Springer. pp 25111949. 
1120 Bradley, R.S., 2003. Climate forcing during the Holocene. In Global Change in the Holocene, 1121 Mackay, A.W., Battarbee, R., Birks, J., Oldfield, F., (eds.). Arnold: London; 10-19.

1122 Bragazza, L., Gerdol, R., 1999. Ecological Gradients in Some Sphagnum Mires in the 1123 Southeastern Alps (Italy). Appl. Veg. Sci. 2, 55-60.

1124 Breeuwer, A., Heijmans, M.M.P.D., Robroek, B.J.M., Berendse, F., 2010. Field simulation of 1125 global change: transplanting northern bog mesocosms southward. Ecosystem 13, 712-726.

1126 Briffa, F.R., Bartholin, T.S., Eckstein D., Jones P.D., Karlén, W., Schweingruber F.H., 1127 Zetterberg, P. 1990. A 1,400-year tree-ring record of summer temperatures in $1128 \quad$ Fennoscandia. Nature 346, 434-439.

1129 Briffa, K., Schweingruber, F., Jones, P., Osborn, T., 1998a. Reduced sensitivity of recent tree 1130 growth to temperature at high northern latitudes. Nature 391, 678-682.

1131 Briffa, K., Schweingruber, F., Jones, P., Osborn, T., Harris, I., Shiyatov, S., Vaganov, A., Grudd, 1132 H., 1998b. Trees tell of past climates: but are they speaking less clearly today? Philos. 1133 Trans. R. Soc. Lond., B 353, 65-73.

1134 Bridge, M.C., Haggart, B.A., Lowe, J.J., 1990. The history and palaeoclimatic significance of 1135 subfossil remains of Pinus sylvestris in blanket peats from Scotland. J. Ecol. 78, 77-99.

1136 Brown, D.M., Munro, M.A.R., Baillie, M.G.L., Pilcher, J.R., 1986. Dendrochronology - The 1137 absolute Irish standard. Radiocarbon 28, 279-283.

1138 Brown, D.M., Baillie, M.G.L., 1992. Construction and dating of a 5000 year English bog oak 1139 tree-ring chronology, in: Bartholin, T.S., Berglund, B.E., Eckstein, D., Schweingruber, 1140 F.H., (Eds.), Tree-rings and environment, Proceedings of the International 1141 Dendrochronology Symposium, Lundqua Report 34, Lund University, pp. 72-75.

1142 Brown, D.M., Baillie, M.G.L., 2012. Confirming the existence of gaps and depletions in the Irish 1143 oak tree-ring record. Dendrochronologia 30, 85-91. doi:10.1016/j.dendro.2010.09.003 
1144 Brown, K.J., Seppä, H., Schoups, G., Fausto, R.S., Rasmussen, P., Birks, H.J.B. 2011. A spatio1145 temporal reconstruction of Holocene temperature change in southern Scandinavia. $1146 \quad$ Holocene 22, 165-177.

1147 Buttler, A., Robroek, B.J.M., Laggoun-Defarge, F., Vincent E.J. Jassey, V.E.J., Pochelon, C., 1148 Bernard, G., Delarue, F., Gogo, S., Mariotte, P., Mitchell, E.A.D., Bragazza, L., 2015. 1149 Experimental warming inter-acts with soil moisture to discriminate plant responses in an $1150 \quad$ ombrotrophic peatland. J. Veg. Sci. 26, 964-974.

1151 Büntgen, U., Tegel, W., Nicolussi, K., McCormick, M., Frank, D., Trouet, V., Kaplan, J.O., 1152 Herzig, F., Heussner, K-U., Wanner, H., Luterbacher, J., Esper, J., 2011. 2500 Years of 1153 European Climate Variability and Human Susceptibility. Science 331, 578-582.

1154 Büntgen, U., Wacker, L., Nicolussi, K., Sigl, M., Güttler, D., Tegel, W., Krusic P.J., Esper, J. 1155 2014. Extraterrestrial confirmation of tree-ring dating. Nature Climate Change 4, 404-405.

1156 Cedro A., Lamentowicz M., 2011. Contrasting responses to environmental changes by pine 1157 (Pinus sylvestris L.) growing on peat and mineral soil: an example from a Polish Baltic bog. 1158 Dendrochronologia 29, 211-217.

1159 Chambers, F.M., Barber, K.E., Maddy, D., Brew, J., 1997. A 5500-year proxy-climate and 1160 vegetation record from blanket mire at Talla Moss, Borders, Scotland. Holocence 7, 391$1161 \quad 399$. doi: $10.1177 / 095968369700700402$.

1162 Chambers, F.M., Charman, D.J., 2004. Holocene environmental change: contributions from the 1163 peatland archive. Holocene 14, 1-6.

1164 Chambers, F.M., Booth, R.K., De Vleeschouwer, F., Lamentowicz, M., Le Roux, G., Mauquoy, 1165 D., Nichols, J.E., van Geel, B., 2012. Development and refinement of proxy-climate 1166 indicators from peats. Quat. Int. 268, 21-33. 
1167 Charman, D.J., 1994. Lateglacial and Holocene vegetation history of the Flow Country, northern $1168 \quad$ Scotland. New Phytol. 127, 155-168.

1169 Charman, D.J., 2002. Peatlands and environmental change. John Wiley \& Sons Ltd. pp: 301.

1170 Charman, D.J., 2010. Centennial climate variability in the British Isles during the mid-late 1171 Holocene. Quat. Sci. Rev. 29, 1539-1554.

1172 Charman, D.J., Blundell, A., Chiverrell, R., Hendon, D., Langdon, P.G., 2006. Compilation of 1173 non-annually resolved Holocene proxy climate records: stacked Holocene peatland palaeo1174 water table reconstructions from northern Britain. Quat. Sci. Rev. 25, 336-350.

1175 Charman, D.J., Barber, K.E., Blaauw, M., Langdon, P.G., Mauquoy, D., Daley, T.J., Hughes, 1176 P.D.M., Karofeld, E. 2009. Climate drivers for peatland palaeoclimate records. Quat. Sci. 1177 Rev. 28, 1811-1819.

1178 Charman, D.J., Beilman, D. W., Blaauw, M., Booth, R. K., Brewer, S., Chambers, F. M., 1179 Christen, J. A., Gallego-Sala, A., Harrison, S. P., Hughes, P. D. M., Jackson, S. T., 1180 Korhola, A., Mauquoy, D., Mitchell, F. J. G., Prentice, I. C., van der Linden, M., De 1181

1187 Charman, D.J., Amesbury, M.J., Hinchliffe, W., Hughes, P.D.M., Mallon, G., Blake, W.H., 1188 Daley, T.J., Gallego-Sala, A.V., Mauquoy, D., 2015. Drivers of Holocene peatland carbon 1189 accumulation across a climate gradient in northeastern North America. Quat. Sci. Rev. 121, 1190 $110-119$. 
1191 Choi, W-J., Chang, S.X. Bhatti, J.S., 2007. Drainage Affects Tree Growth and C and N Dynamics 1192 in a Minerotrophic Peatland. Ecology 88, 443-453.

1193 Christensen, K., 2007. Forhistorisk dendrokronologi i Danmark. Kuml 217-235. (in Danish)

1194 Clarkson, B.R., Schipper, L.A., Clarkson, B.D., 2004. Vegetation and peat characteristics of 1195 restiad bogs on Chatham Island (Rekohu), New Zealand. NZ J. Bot. 42, 293-312.

1196 Cook, E.R., Seager, R., Kushnir, Y., Briffa, K.R., Büntgen, U., Frank, D., Krusic, P.J., Tegel, W., 1197 van der Schrier, G., Andreu-Hayles, L., Baillie, M., Baittinger, C., Bleicher, N., Bonde, N., 1198 Brown, D., Carrer, M., Cooper, R., Čufar, K., Dittmar, C., Esper, J., Griggs, C., Gunnarson, 1199 B., Günther, B., Gutierrez, E., Haneca, K., Helama, S., Herzig, F., Heussner, K-U., 1200 Hofmann, J., Janda, P., Kontic, R., Köse, N., Kyncl, T., Levanič, T., Linderholm, H., 1201 1202

1206 Cowan, I.R., 1965. Transport of water in the soil-plant-atmosphere system. J. Appl. Ecol. 2, 221239. doi: $10.2307 / 2401706$.

1208 Crawford, R.M.M., 1989. Studies in plant survival. Blackwell Scientific Publications, Oxford.

1209 Dang, Q.L., Lieffers, V.J., 1989. Assessment of patterns of response of tree ring growth of black 1210 spruce following peatland drainage. Can. J. For. Res. 19, 924-929.

1211 Dang, Q.L., Lieffers, V.J., Rothwell, R.L., Macdonald, S.E., 1991. Diurnal variation and 1212 interrelations of ecophysiological parameters in three peatland woody species under 1213 different weather and soil moisture conditions. Oecologia 8, 317-324. 
1214 Daniell, J.R.G., 1997. The Late-Holocene palaeoecology of Scots pine (Pinus sylvestris L.) in 1215 north- west Scotland. Durham theses, Durham University.

1216 Dansgaard, W., White, J.W.C., Johnsen, S.J., 1989. The abrupt termination of the Younger Dryas $1217 \quad$ climate event. Nature 339, 532-534.

1218 D’Arrigo, R., Wilson, R., Jacoby, G., 2006. On the long-term context for late twentieth century 1219 warming. J. Geophys. Res. 111. D03103, doi:10.1029/2005JD006352

1220 D'Arrigo R., Wilson R., Liepert B., Cherubini P., 2008. On the 'Divergence Problem' in 1221 Northern Forests: A review of the tree-ring evidence and possible causes, Global Planet. $1222 \quad$ Change 60, 289-305.

1223 Dau, J.H.C.,1829. Allerunterthänigster Bericht an die Königliche Dänische Rentekammer über 1224 die Torfmoore Seelands. Glydendahl und Hinnichs, Copenhagen and Leipzig.

1225 DeBell, D.S., Hook, D.D., McKee, W.H., Askew, J.L., 1984. Growth and Physiology of Loblolly 1226 Pine Roots Under Various Water Table Level and Phosphorus Treatments. Forest Sci. 30, $1227 \quad 705-714$.

1228 Delorme, A., Leuschner, H.H., Höffle H.C., Tüxen, J., 1981. Über die Anwendung der 1229 Dendrochronologie in der Moorforschung am Beispiel subfossiler Eichenstämme aus $1230 \quad$ Niedersächsischen Mooren. Eiszeitalter und Gegenwart 31, 135-158.

1231 Digerfeldt, G., 1988. Reconstructions and regional correlation of Holocene lake-level fluctuations 1232 in Lake Bysjön, South Sweden. Boreas 17, 165-182.

1233 Douglass, A.E., 1941. Crossdating in dendrochronology. J. Forest. 39, 825-831.

1234 Dubé, S., Plamondon A.P., Rothwell, R.L., 1995 Watering up After Clear-Cutting on Forested 1235 Wetlands of the St. Lawrence Lowland. Water Resour. Res. 31, 1741-1750. doi: $1236 \quad 10.1029 / 95$ WR00427. 
1237 Eckstein, J., Leuschner, H.H., Bauerochse, A., Sass-Klaassen, U., 2009. Subfossil bog-pine 1238 horizons document climate and ecosystem changes during the Mid-Holocene. 1239 Dendrochronologia 27, 129-146.

1240 Eckstein, J., Leuschner, H.H., Giesecke, T., Shumilovskikh, L., Bauerochse, A., 2010. 1241 Dendroecological investigations at Venner Moor (northwest Germany) document climate1242 driven woodland dynamics and mire development in the period 2450-2050 BC. Holocene $1243 \quad 20,231-244$.

1244 Eckstein, J., Leuschner, H.H., Bauerochse, A., 2011. Mid-Holocene pine woodland phases and 1245 mire development - significance of dendroecological data from subfossil trees from 1246 northwest Germany. J. Veg. Sci. 22, 781-794.

1247 Edvardsson, J., 2016. Mid- to Late Holocene climate transition and moisture dynamics inferred 1248 from South Swedish tree-ring data. J. Quat. Sci. 31, 256-264.

1249 Edvardsson, J., Leuschner, H.H., Linderson, H., Linderholm, H.W., Hammarlund, D., 2012a. 1250 South Swedish bog pines as indicators of Mid-Holocene climate variability. 1251 Dendrochronologia 30, 93-103.

1252 Edvardsson, J., Linderson, H., Rundgren, M., Hammarlund, D., 2012b. Holocene peatland 1253 development and hydrological variability inferred from bog-pine dendrochronology and 1254 peat stratigraphy - a case study from southern Sweden. J. Quat. Sci. 27, 553-563.

1255 Edvardsson, J., Edwards, T.W.D., Linderson, H., Hammarlund, D., 2014a. Climate forcing of 1256 growth depression in subfossil South Swedish bog pines inferred from stable isotopes. 1257 Dendrochronologia 32, 55-61.

1258 Edvardsson, J., Poska, A., Van der Putten, N., Rundgren, M., Linderson, H., Hammarlund D., 1259 2014b. Late-Holocene expansion of a South Swedish peatland and its impact on marginal 
ecosystems : Evidence from dendrochronology, peat stratigraphy and palaeobotanical data. Holocene 24, 466-476.

1262 Edvardsson, J., Rimkus, E., Corona, C., Šimanauskiene, R., Kažys, J., Stoffel, M., 2015 a. 1263 Exploring the impact of regional climate and local hydrology on Pinus sylvestris L. growth variability - A comparison between pine populations growing on peat soils and mineral soils in Lithuania. Plant Soil 392, 345-356.

1266 Edvardsson, R., Šimanauskiene, R., Taminskas, J., Baužiene, J., Stoffel, M., 2015b. Increased tree establishment in Lithuanian peat bogs detected using a combination of field and remotely sensed approaches. Sci. Total Environ. 505, 113-120.

1269 Edvardsson J., Hansson A., 2015. Multiannual hydrological responses in Scots pine radial growth 1270 within raised bogs in southern Sweden. Silva Fenn. 49, 1-14.

1271 Edvardsson, J., Corona, C., Mažeika, J., Pukienè, R., Stoffel, M., 2016a. Recent advances in long-term climate and moisture reconstructions from the Baltic region: Exploring the potential for a new multi-millennial tree-ring chronology. Quat. Sci. Rev. 131, 118-126.

1274 Edvardsson, J., Adolphi, F., Linderholm, H.W., Corona, C., Muscheler, R., Stoffel, M. $2016 \mathrm{~b}$. 1275 Periodicities in Mid- to Late Holocene peatland hydrology identified from Swedish and 1276 Lithuanian tree-ring data. Quat. Sci. Rev. 137, 200-208.

1277 Eronen M., Hyvärinen H., Zetterberg P., 1999. Holocene humidity changes in northern Finnish 1278 Lapland inferred from lake sediments and submerged Scots pines dated by tree-rings.

1280 Eronen M., Zetterberg P., Briffa K. R., Lindholm M., Meriläinen J., Timonen M., 2002. The 1281 supra-long Scots pine tree-ring record for Finnish Lapland: Part 1, chronology construction 1282 and initial inferences. Holocene 12, 673-680. 
1283 Fox, A.M., Huntley, B., Lloyd, C.R., Williams, M., Baxter, R., 2008. Net ecosystem exchange 1284 over heterogeneous Arctic tundra: Scaling between chamber and eddy covariance measurements. Global Biogeochem. Cycle 22, doi:10.1029/2007GB003027.

1286 Fragnière, J., Bétrisey, S., Cardinaux, L., Stoffel, M., Kozlowski, G., 2015. Fighting their last 1287 stand? A global analysis of the distribution and conservation status of gymnosperms. J. 1288 Biogeogr. 42, 809-820.

1289 Freléchoux, F., Buttler, A., Schweingruber, F.H., Gobat, J.-M., 2000. Stand structure, invasion, 1290 and growth dynamics of bog pine (Pinus uncinata var. rotundata) in relation to peat cutting and drainage in the Jura Mountains, Switzerland. Can. J. For. Res. 30, 1114-1126.

1292 Friedrich, M., Remmele, S., Kromer, B., Hofmann, J., Spurk, M., Kaiser, K.F., Orcel, C., Küppers, M., 2004. The 12,460-year Hohenheim oak and pine tree-ring chronology from Central Europe-A unique annual record for radiocarbon calibration and paleoenvironment reconstructions. Radiocarbon 46, 1111-1122.

1296 Fritts, H.C., 1976. Tree Rings and Climate. Academic Press: London.

1297 Gear, A.J., Huntley, B., 1991. Rapid changes in the range limits of Scots Pine 4000 years ago. $1298 \quad$ Science 251, 544-547.

1299 Godwin, H., 1975. The History of the British Flora, 2nd. Cambridge University Press: $1300 \quad$ Cambridge.

1301 Gong, J., Wang, K., Kellomäki, S., Zhang, C., Martikainen, P.J., Shurpali, N., 2012. Modeling 1302 water table changes in boreal peatlands of Finland under changing climate conditions. Ecol. $1303 \quad$ Model. 244, 65-78.

1304 Granlund, E., 1932. De svenska högmossarnas geologi. Sveriges Geologiska Undersökning Ser. 1305 C 373: Stockholm. 
1306 Grootjans, A.P. Schipper, P.C., van der Windt H.J., 1985. Influence of drainage on N1307 mineralization and vegetation response in wet meadows. Acta Oecologica Planta 6, 403$1308 \quad 417$.

1309 Grudd, H., Briffa, K.R., Gunnarson, B.E., Linderholm, H.W., 2000. Swedish tree rings provide 1310 new evidence in support of a major, widespread environmental disruption in $1628 \mathrm{BC}$. $1311 \quad$ Geophys. Res. Lett. 27, 2957-2960.

1312 Grudd, H., Briffa, K.R., Karlén, W., Bartholin, T.S., Jones, P.D., Kromer, B., 2002. A 7400-year 1313 tree-ring chronology in northern Swedish Lapland: natural climatic variability expressed on 1314 annual to millennial timescales. Holocene 12, 643-656.

1315 Guiot J., Boucher E., Gea-Izquierdo G., 2014. Process models and model-data fusion in 1316 dendroecology. Front. Ecol. Evol. 52, 1-12.

1317 Gunnarson, B.E., 1999. A 200-year tree-ring chronology of pine from a raised bog in Sweden: 1318 implication for climate change? Geogr. Ann. A. 81, 421-430.

1319 Gunnarson, B.E., 2008. Temporal distribution pattern of subfossil pines in central Sweden: 1320 perspective on Holocene humidity fluctuations. Holocene 18, 69-77.

1321 Gunnarson, B.E., Borgmark, A., Wastegård, S., 2003. Holocene humidity fluctuations in Sweden 1322 inferred from dendrochronology and peat stratigraphy. Boreas 32, 347-360.

1323 Hartley, I.P., Hill, T.C., Wade, T., Clement, R.J., Moncrieff, J.B., Prieto-Blanco, A., Disney, 1324 M.I., Huntley, B., Williams, M., Howden, N.J.K., Wookey, P.A., Baxter, R., 2015. 1325 Quantifying landscape-level methane fluxes in subarctic Finland using a multi-scale 1326 approach. Global Change Biol., doi 10.1111/gcb.12975.

1327 Helama, S., Lindholm, M., Timonen, M., Eronen, M., 2004. Dendrochronologically dated 1328 changes in the limit of pine in northernmost Finland during the past 7.5 millennia. Boreas 1329 $33,250-259$. 
1330 Helama S., Lindholm M., Timonen M., Eronen M., 2005. Mid- and late Holocene tree population 1331 density changes in northern Fennoscandia derived by a new method using megafossil pines 1332 and their tree-ring series. J. Quat. Sci. 20, 567-575.

1333 Helama S., Mielikäinen K., Timonen M., Eronen M., 2008. Finnish supra-long tree-ring 1334 chronology extended to 5634 BC. Norwegian J. Geogr. 62, 271-277.

1335 Helama S., Eronen M., Timonen M., 2010. Dendroécologie des bois fossiles dans le nord de la 1336 Laponie, in: La Dendroécologie: Principes, méthodes et applications (Eds.), Payette, S., 1337 Filion, L., Presses de l’Université Laval, Québec, pp. 709-730.

1338 Helama S., Seppä H., Bjune A.E., Birks H.J.B., 2012. Fusing pollen-stratigraphic and 1339 dendroclimatic proxy data to reconstruct summer temperature variability during the past 7.5 $1340 \quad$ ka in subarctic Fennoscandia. J. Paleolimnol. 48, 272-286.

1341 Hammarlund, D., Björck, S., Buchardt, B., Israelson, C., Thomsen, C.T., 2003. Rapid 1342 hydrological changes during the Holocene revealed by stable isotope records of lacustrine 1343 carbonates from Lake Igelsjön, southern Sweden. Quat. Sci. Rev. 22, 353-370.

1344 Heikkilä, M., Seppä, H., 2010. Holocene climate dynamics in Latvia, eastern Baltic region: a 1345 pollen-based summer temperature reconstruction and regional comparison. Boreas 39, 705$1346 \quad 719$.

1347 Hiederer, R., Köchy, M., 2012. Global Soil Organic Carbon Estimates and the Harmonized $1348 \quad$ World Soil Database, Scientific and Technical Research series, doi:10.2788/13267

1349 Hillel, D., 1971. Soil and water: physical principles and processes. Academic Press, Inc., New $1350 \quad$ York.

1351 Holmgren, M., Lin, C-Y., Murillo, J.E., Nieuwenhuis, A., Penninkhof, J., Sanders, N., van Bart, 1352 T., van Veen, H., Vasander, H., Vollebregt, M.E., Limpens, J., 2015. Positive shrub-tree 1353 interactions facilitate woody encroachment in boreal peatlands. J. Ecol. 103, 58-66. 
1354 Hu, F.S., Kaufman, D., Yoneji, S., Nelson, D., Shemesh, A., Huang, Y., Tian, J., Bond, G., 1355 Clegg, B., Brown, T., 2003. Cyclic variation and solar forcing of Holocene climate in the $1356 \quad$ Alaskan subarctic. Science 301, 1890-1893.

1357 Hughes, P.D.M., 2003. Review of the routes to ombrotrophy in raised bogs in Britain and Ireland, 1358 in: Bauerochse, A., Hassmann, H., (Eds.), Peatlands; Proceedings of the Peatland 1359 Conference 2002 in Hannover, Germany. Rahden 2003, pp. 188-195.

1360 Hughes, P.D.M., Blundell, A., Charman, D.J., Bartlett, S., Daniell, J.R.G., Wojatschke, A., 1361 Chambers, F.M., 2006. An 8500 cal. year multi-proxy climate record from a bog in eastern 1362 Newfoundland: contributions of meltwater discharge and solar forcing. Quat. Sci. Rev. 25, $1363 \quad 1208-1227$.

1364 Hunt, R.J., Walker, J.F., Krabbenhoft, D.P., 1999. Characterizing hydrology and the importance 1365 of ground-water discharge in natural and constructed wetlands. Wetlands 19, 458-472.

1366 Huntley, B., Prentice, I.C., 1988. July temperature in Europe from pollen data 6000 years before 1367 present. Science 241, 687-689.

1368 Huntley, B., Daniell, J.R.G., Allen, J.R.M., 1997. Scottish vegetation history: Highlands. Bot. J. $1369 \quad$ Scotland 49, 163-175.

1370 Ingram, H.A.P., 1983. Hydrology, in: Gore A.J.P., (Eds.), Mires: Swamp, Bog, Fen, and Moor. 1371 Elsevier, Amsterdam, pp. 67-158.

1372 Jansen, E., Overpeck, J., Briffa, K.R., Duplessy, J.-C., Joos, F., Masson-Delmotte, V., Olago, D., 1373 Otto Bliesner, B., Peltier, W.R., Rahmstorf, S., Ramesh, D., Raynaud, D., Rind, D., 1374 Solomina, O., Villalba, R., Zhang, D., 2007. Palaeoclimate. In: Solomon, S., Qin, D., 1375 Manning, M., Chen, Z., Marquis, M., Averyt, K.B., Tignor, M., Miller, H.L., (Eds.), 1376 Climate Change 2007. The Physical Science BasisContribution of Working Group I to the 

University Press, Cambridge and New York.

Jansma, E., 1996. An 1100-year tree-ring chronology of oak for the Dutch coastal region, in: Dean, J.S., Meko, D.M., Swetnam, T.S., (Eds.), Tree-rings, environment and humanity, Proceedings of the International Conference, Tucson, Arizona, 17-21 May, Tucson: Radiocarbon, pp. 769-778.

1383 Jeffers, S.E., Nogué, S., Willis, K.J., 2015. The role of palaeoecological records in assessing 1384 ecosystem services. Quat. Sci. Rev. 112, 17-32.

1385 Jessen, C.A., Rundgren, M., Björck, S., Hammarlund, D., 2005. Abrupt climatic changes and an 1386 unstable transition into a late Holocene Thermal Decline: a multiproxy lacustrine record 1387 from southern Sweden. J. Quat. Sci. 20, 349-362.

1388 Joosten, H., Clarke, D., 2002. Wise Use of Mires and Peatlands - Background and Principles, 1389 including a Framework for Decision-making. International Mire Conservation 1390 Group/International Peat Society, Jyväskylä, Finland.

1391 Joosten, H., Couwenberg, J., 2008. Peatlands and Carbon. In: Parish, F., et al. Assessment on 1392 1393 Wetlands International Wageningen, pp. 99-117.

1394 Juutinen, S., Bubier, J.L., Moore, T.R., 2010. Responses of vegetation and ecosystem $\mathrm{CO}_{2}$ 1395 exchange to 9 years of nutrient addition at Mer Bleue bog. Ecosystems 13, 874-887.

1396 Kellner, E., 2001. Surface energy fluxes and control of evapotranspiration from a Swedish 1397 Sphagnum mire. Agr. Forest Meteorol. 110, 101-123.

1398 Kilian, M.R., van der Plicht, J. van Geel, B., 1995. Dating raised bogs: New aspects of AMS ${ }^{14} \mathrm{C}$ 1399 wiggle matching, a reservoir effect and climatic change. Quat. Sci. Rev. 14, 959-966. 
1400 Kokkonen, P., 1923. Beobachtungen über das Wurzelsystem der Kiefer in Moorböden. Acta $1401 \quad$ Forestalia Fennica 25, 1-20.

1402 Kozlowski, T.T., 1984. Plant responses to flooding of soil. Bioscience 34, 162-167.

1403 Kozlowski, T.T., 1997. Responses of woody plants to flooding and salinity. Tree Physiol. $1404 \quad$ Monograph 1, 1-29.

1405 Kozlowski, T.T., Pallardy, S.G., 1984. Effects of flooding on water, carbohydrate, and mineral 1406 relations, in: Flooding and Plant Growth, (Eds.), Kozlowski, T.T., Academic Press, 1407 Orlando, FL, pp. 165-193.

1408 Kozlowski, T.T., Pallardy, S.G., 1997. Growth control in woody plants. Academic Press, San 1409 Diego.

1410 Kozlowski, G., Stoffel, M., Cardinaux, L., Bétrisey, S., Mota, M., 2015, Hydrophobia of 1411 gymnosperms: myth or reality? Ecohydrology 8, 105-112.

1412 Krąpiec, M., Szychowska-Krąpiec, E., 2016. Subfossil bog-pine chronologies from The Puścizna 1413 Wielka raised bog, Orawa Basin, southern Poland. Quat. Int. 1414 doi:10.1016/j.quaint.2015.12.045

1415 Kullman, L., 1987. Sequences of Holocene forest history in the Scandes, inferred from 1416 megafossil Pinus sylvestris. Boreas 16, 21-26.

1417 Labuhn, I., Genty, D., Vonhof, H., Bourdin, C., Blamart, D., Douville, E., Ruan, J., Cheng, H., 1418 Edwards, R.L., Pons-Branchu, E., Pierre, M., 2015. A high-resolution fluid inclusion $\delta^{18} \mathrm{O}$ 1419 record from a stalagmite in SW France: modern calibration and comparison with multiple $1420 \quad$ proxies. Quat. Sci. Rev. 110, 152-165.

1421 Lageard, J.G.A., Chambers, F.M., Thomas, P.A., 1995. Recording and Reconstruction of Wood 1422 Macrofossils in Three-Dimensions J. Archaeol. Sci. 22, 561-567. 
1423 Lageard, J.G.A., Chambers, F.M., Thomas, P.A., 1999. Climatic significance of the 1424 marginalisation of Scots pine (Pinus sylvestris L.) circa $2500 \mathrm{BC}$ at White Moss, Cheshire, $1425 \quad$ UK. Holocene 9, 321-331.

1426 Lageard, J.G.A., Thomas, P.A., Chambers, F.M., 2000. Using fire scars and growth release in 1427 subfossil Scots pine to reconstruct prehistoric fires. Palaeo 164, 87-99.

1428 Langdon, P.G., Barber, K.E., 2005. The climate of Scotland over the last 5000 years inferred 1429 from multiproxy peatland records: inter-site correlations and regional variability. J. Quat. $1430 \quad$ Sci. $20,549-566$.

1431 Lappalainen, E., 1996. Global peat resources, International Peat Society \& Geological Survey of 1432 Finland, Jyväskylä, Finland.

1433 Leuschner, H.H., 1992. Subfossil trees, in: Bartholin, T.S., Berglund, B.E., Eckstein, D., 1434 Schweingruber, F.H., Eggertsson, O. (Eds.), Tree Rings and Environment: Proceedings of 1435 the International Symposium, Ystad, South Sweden. Lundqua Report 34, pp. 193-197.

1436 Leuschner, H.H., Delorme, A., 1984. Verlängerung der Göttinger Eichenjahrringchronologien für 1437 Nord- und Süddeutschland bis zum Jahr 4008 v Chr. Forstarchiv 5, 1-4.

1438 Leuschner, H.H., Delorme, A., Höfle, H.C., 1987. Dendrochronological study of oak trunks 1439 found in bogs of northwest Germany, in: Jacoby Jr., G.C., Hornbeck, J.W., (Eds.), 1440 Proceedings of the International Symposium on Ecological Aspects of Tree-Ring Analysis. 1441 U.S. Department of Energy, Publication CONF-8608144, pp. 298-318.

1442 Leuschner, H.H., Delorme, A., 1988. Tree-ring work in Göttingen: absolute oak chronologies 1443 back to 6255 BC, in: Hackens, T., Munaut A.V., Till, C., (Eds.), Wood and Archaeology. $1444 \quad$ PACT 22, pp. 123-132. 
1445 Leuschner, H.H., Spurk, M., Baillie, M., Jansma, E., 2000. Stand dynamics of prehistoric oak 1446 forests derived from dendrochronologically dated subfossil trunks from bogs and riverine 1447 sediments in Europe. Geolines 11, 118-121.

1448 Leuschner, H.H., Sass-Klaassen, U., Jansma, E., Baillie, M.G.L., Spurk, M., 2002. Subfossil 1449 European bog oaks: population dynamics and long-term growth depressions as indicators of 1450 changes in the Holocene hydro-regime and climate. Holocene 12, 695-706.

1451 Leuschner, H.H., Bauerochse, A., Metzler, A., 2007. Environmental change, bog history and 1452 human impact around 2900 B.C. in NW Germany - preliminary results from a 1453 dendroecological study of a sub-fossil pine woodland at Campemoor, Dümmer Basin. Veg. $1454 \quad$ Hist. Archaeobot. 16, 183-195.

1455 Lewis, F. J., 1906. The plant remains in Scottish peat mosses I. The Scottish Southern Uplands. 1456 Transactions of the Royal Society of Edinburgh 41, 699-723.

1457 Lewis, F.J., 1908. The plant remains in Scottish peat mosses II. The Scottish Highlands. 1458 Transactions of the Royal Society of Edinburgh 45, 335-360.

1459 Limpens, J., Granath, G., Gunnarsson, U., Aerts, R., Bayley, S., Bragazza, L., Bubier, J., Buttler, 1460 A., Van den Berg, L.J.L., Francez, A.J., Gerdol, R., Grosvernier, P., Heijmans, M.M.P.D., 1461 Hoosbeek, M.R., Hotes, S., Ilomets, M., Leith, I., Mitchell, E.A.D., Moore, T., Nilsson, 1462 1463 Wiedermann, M.M., Williams, B.L., Xu, B., 2011. Climatic modifiers of the response to 1464 nitrogen deposition in peat-forming Sphagnum mosses: a meta-analysis. New Phytol. 191, $1465 \quad 496-507$.

1466 Limpens, J., Holmgren, M., Jacobs, C.M.J., Van der Zee, S.E.A.T.M., Karofeld, E., Berendse, F. 1467 2014a. How does tree density affect water loss of peatlands? A mesocosms experiment. $1468 \quad$ PLOS One 9, doi: 10.1371/journal.pone.0091748 
1469 Limpens, J., van Egmond, E., Li, B., Holmgren, M., 2014b. Do plant traits explain tree seedling $1470 \quad$ survival in bogs? Funct. Ecol. 28, 283-290.

1471 Lindbladh, M., Fraver, S., Edvardsson, J., Felton, A., 2013. Past forest composition, structures 1472 and processes - How paleoecology can contribute to forest conservation. Biol. Conserv. $1473 \quad 168,116-127$.

1474 Linderholm, H.W., 2001. Climate influence on Scots pine growth on dry and wet soils in the central Scandinavian mountains, interpreted from tree-ring widths. Silvia Fenn. 35, 415424.

1477 Linderholm, H.W., Moberg, A., Grudd, H., 2002. Peatland pines as climate indicators? - A 1478 regional comparison of the climatic influence on Scots pine growth in Sweden. Can. J. For. $1479 \quad$ Res 32, 1400-1410.

1480 Linderholm H.W., Leine M. 2004. Assessing twentieth century tree-cover changes on a southern $1481 \quad$ Swedish peatland combining dendrochronolgical and remote sensing methods. Wetlands $24,357-363$.

1483 Linderholm, H.W., Björklund, J., Seftigen, K., Gunnarson, B.E., Fuentes, M., 2014. 1484 Fennoscandia revisited: a spatially improved tree-ring reconstruction of summer 1485 temperatures for the last 900 years. Clim. Dyn. 45, 933-947. doi:10.1007/s00382-0141486 2328-9.

1487 Loader, N.J., Switsur, V.R., 1996. Reconstructing past environmental change using stable 1488 isotopes in tree-rings. Trans. Bot. Soc. 48, 65-78.

1489 Loisel, J., Yu, Z., Beilman, D.W., Camill, P., Alm, J., Amesbury, M.J., Anderson, D., Andersson, 1490 S., Bochicchio, C., Barber, B., Belyea, L.R., Bunbury, J., Chambers, F.M., Charman, D.J., 1491 De Vleeschouwer, F., Fiałkiewicz-Kozieł, B., Finkelstein, S.A., Gałka, M., Garneau, M., 1492 Hammarlund, D., Hinchcliffe, W., Holmquist, J., Hughes, P., Jones, M.C., Klein, E.S., 
Kokfelt, U., Korhola, A., Kuhry, P., Lamarre, A., Lamentowicz, M., Large, D., Lavoie, M., MacDonald, G., Magnan, G., Mäkilä, M., Mallon, G., Mathijssen, P., Mauquoy, D., McCarroll, J., Moore T.R., Nichols, J., O’Reilly, B., Oksanen, P., Packalen, M., Peteet, D., Richard, P.J.H., Robinson, S., Ronkainen, T., Rundgren, M., Sannel, A.B.K., Tarnocai, C., Thom, T., Tuittila, E-S., Turetsky, M., Väliranta, M., van der Linden, M., van Geel. B., van Bellen, S., Vitt, D., Zhao, Y., Zhou, W., 2014. A database and synthesis of northern peatland soil properties and Holocene carbon and nitrogen accumulation. Holocene 24,

1501 MacDonald, S.E., Yin, F., 1999. Factors influencing size inequality in peatland black spruce and 1502 tamarack: evidence from a post-drainage release growth. J. Ecol. 87, 404-412.

MacDonald, G.M., Beilman, D.W., Kremenetski, K.V., Sheng, Y., Smith, L.C., Velichko, A.A., 2006. Rapid early development of circumarctic peatlands and atmospheric $\mathrm{CH}_{4}$ and $\mathrm{CO}_{2}$ variations. Science 314, 285-288.

1506 Magny, M., 2004. Holocene climate variability as reflected by mid-European lake-level fluctuations and its probable impact on prehistoric human settlements. Quat. Int. 113, 65-

Magny, M., 2013. Orbital, ice-sheet, and possible solar forcing of Holocene lake-level fluctuations in west-central Europe: A comment on Bleicher. Holocene 23, 1202-1212.

Mann, M.E., Zhang, Z., Hughes, M.K., Bradley, R.S., Miller, S.K., Rutherford, S., Ni, F., 2008. Proxy-based reconstructions of hemispheric and global surface temperature variations over the past two millennia. Proc. Natl. Acad. Sci. 105, 13252-13257.

1514 Mannerkoski, H., 1991. Relation between tree roots and soil aeration on drained peatlands, in: 1515 Jeglum, J.K., Overend, R.P., (Eds.), Peat and Peatlands - Diversification and Innovation. 1516 Canadian Society for Peat and Peatlands, pp. 109-114. 
1517 Marcott, S.A., Shakun, J.D., Clark, P.U., Mix, A.C., 2013. A Reconstruction of Regional and 1518 Global Temperature for the Past 11,300 Years. Science 339, 1198-1201. doi: $1519 \quad 10.1126 /$ science. 1228026

1520 Mauquoy, D., Yeloff, D., van Geel, B., Charman, D.J., Blundell, A., 2008. Two decadally 1521 resolved records from north-west European peat bogs show rapid climate changes 1522 associated with solar variability during the mid-late Holocene. J. Quat. Sci. 23, 745-763. 1523 doi: $10.1002 /$ jqs. 1158

1524 McCarroll, D., Loader, N.J., 2004. Stable isotopes in tree rings. Quat. Sci. Rev. 23, 771-801.

1525 McCarroll, D., Loader, N.J., Jalkanen, R., Gagen, M.H., Grudd, H., Gunnarson, B.E., Kirchhefer, 1526 A.J., Friedrich, M., Linderholm, H.W., Lindholm, M., Boettger, T., Los, S.O., Remmele, S., 1527 Kononov, Y.M., Yamazaki, Y.H., Young, G.H.F., Zorita, E., 2013. A 1200-year multiproxy 1528 record of tree growth and summer temperature at the northern pine forest limit of Europe. $1529 \quad$ Holocene 23, 471-484.

1530 McGeever, A.H., Mitchell, F.J.G., 2015. Pine stumps in Irish peats: is their occurrence a valid 1531 proxy climate indicator? J. Quat. Sci. 30, 489-496. doi: 10.1002/jqs.2793.

1532 Mellström, A., van der Putten, N., Muscheler, R., de Jong, R., Björck, S., 2015. A shift towards 1533 wetter and windier conditions in southern Sweden around the prominent solar minimum 15342750 cal a BP. J. Quat. Sci. 30, 235-244.

1535 Melvin, T.M., Briffa, K.R., 2014. CRUST: Software for the implementation of Regional 1536 Chronology Standardisation: Part 1. Signal-Free RCS. Dendrochronologia 32, 7-20.

1537 Mitsch, W.J., Nahlik, A.M., Bernal, B., Zhang, L., Anderson, C.J., Jørgensen, S.E., Mander, Ü., 1538 Brix, H., 2013. Wetlands, carbon, and climate change. Landscape Ecol. 28, 583-597. 
1539 Moberg, A., Sonechkin, D.M., Holmgren, K., Datsenko, N.M., Karlén, W., 2005. Highly variable 1540 Northern Hemisphere temperatures reconstructed from low- and high-resolution proxy data. $1541 \quad$ Nature 433, 613-617.

1542 Moir, A.K., 2005. Dendrochronological analysis of sub-fossil pine in N. Scotland to examine the 1543 timing and extent of a c. 4000 cal. yr BP climatic event. Quaternary Newsletter 104, 75-78.

1544 Moir, A.K., Leroy, S.A.G., Brown, D., Collins, P.E.F., 2010. Dendrochronological evidence for a 1545 lower water-table on peatland around 3200-3000 BC from subfossil pine in northern $1546 \quad$ Scotland. Holocene 20, 931-942.

1547 Moir, A.K., Leroy, S.A.G., Helama, S., 2011. Role of substrate on the dendroclimatic response of 1548 Scots pine from varying elevations in Northern Scotland. Can. J. For. Res. 41, 822-838. 1549 doi:10.1139/X10-241.

1550 Moir, A., 2012. Development of a Neolithic pine tree-ring chronology from northern Scotland. J. 1551 Quat. Sci. 27, 503-508.

1552 Montanarella, L., Jones, R.J.A., Hiederer, R., 2006. The distribution of peatland in Europe. Mires 1553 and Peat 1, http://www.mires-and-peatland.net

1554 Morley A., Rosenthal Y., deMenocal P., 2014. Ocean-atmosphere climate shift during the mid-to1555 late Holocene transition. Earth Planet. Sci. Lett. 388, 18-26

1556 Munaut, A.V., 1967. Etude paléo-écologique d'un gisement tourbeux situé à Terneuzen (Pays1557 Bas). Berichten van de Rijksdienst voor het Oudheidkundig Bodemonderzoek 17, 7-27.

1558 Munaut, A.V., Casparie, W.A., 1971. Etude dendrochronologique des Pinus sylvestris L. 1559 subfossiles provenant de la tourbière d'Emmen (Drenthe, Pays-Bas). Rev. Palaeobot. and $1560 \quad$ Palynology 11, 201-226.

1561 Muscheler, R., Joos, F., Mueller, S.A., Snowball, I., 2005. How unusual is today’s solar activity? $1562 \quad$ Nature 436, E3-E4. 
1563 Nesje, A., Kvamme, M., Rye, N., Løvlie, R., 1991. Holocene glacial and climate history of the 1564 Jostedalsbreen region, western Norway; evidence from lake sediments and terrestrial deposits. Quat. Sci. Rev. 10, 87-114. doi:10.1016/0277-3791(91)90032-P

1566 Nicolussi, K., Kaufmann, M., Patzelt, G., van der Plicht, J., Thurner, A., 2005. Holocene tree-line variability in the Kauner Valley, Central Eastern Alps, indicated by dendrochronological analysis of living trees and subfossil logs. Veget. Hist. Archaeobot. 14, 221-234. doi:10.1007/s00334-005-0013-y.

Nicolussi, K., Kaufmann, M., Melvin, T.M., van der Plicht, J., Schießling, P., Thurner, A., 2009. A 9111 year long conifer tree-ring chronology for the European Alps: a base for environmental and climatic investigations. Holocene 19, 909-920.

1574 Nicolussi, K., Schlüchter, C., 2012. The 8.2 ka event - Calendar-dated glacier response in the $1575 \quad$ Alps. Geology 40, 819-822.

1576 Nielsen, J.K., Helama, S., 2012. Christian Theodor Vaupell, a Danish 19th century naturalist and a pioneering developer of the Quaternary geoscience. Hist. Geo- Space Sci. 3, 143-150.

1578 Osundina, M.A., Osonubi, O., 1989. Adventitious roots, leaf abscissionand nutrient status of flooded Gmelina and Tectona seedlings. Tree Physiol. 5, 473-483.

1580 Ohlson, M., Halvorsen-Økland, R., Nordbakken, J-F., Dahlberg, B., 2001. Fatal interactions between Scots pine and Sphagnum mosses in bog ecosystems. Oikos 94, 425-432.

1582 Patterson III, W.A., Backman, A.E., 1988. Fire and disease history of forests. In Vegetation history, pp. 603-632. Springer Netherlands.

1584 Pearson, G.W., Pilcher, J.R., Baillie, M.G.L., Corbett, D.M., Qua, F., 1986. High-precision ${ }^{14}$ C 1585 measurement of Irish oaks to show the natural ${ }^{14} \mathrm{C}$ variations from AD 1840 to $5210 \mathrm{BC}$. $1586 \quad$ Radiocarbon 28, 911-934. 
1587 Petzelberger, B.E.M., Behre, K., Geyh, M.A., 1999. Beginn der Hochmoorentwicklung und 1588 Ausbreitung der Hochmoore in Nordwestdeutschland - erste Ergebnisse eines neuen $1589 \quad$ Projektes. Telma 29, 21-38.

1590 Pilcher, J.R., 1973. Tree-ring research in Ireland. Tree-Ring Bulletin 33, 1-5.

1591 Pilcher, J.R., Hillam, M.G., Baillie, M.G.L., Pearson, G.W., 1977. A long sub-fossil oak tree-ring 1592 chronology from the north of Ireland. New Phytol. 79, 713-729.

1593 Pilcher, J.R, Baillie, M.G.L., Schmidt, B, Becker, B., 1984. A 7272-year tree-ring chronology for 1594 western Europe. Nature 312, 150-152.

1595 Pilcher, J.R., Baillie, M.G.L., Brown, D.M., McCormac, F.G., MacSweeney, P.B., McLawrence, 1596 1597 A.S., 1995. Dendrochronology of subfossil pine in the north of Ireland. J. Ecol. 83, 665671.

Pilcher, J.R., Baillie, M.G.L., Brown, D.M., McCormac, F.G., 1996. Hydrological data from the long Irish subfossil oak records, in: Dean, J.S., Meko, D.M., Sweatnam, T.W., (Eds.). Tree Rings, Environment and Humanity, Radiocarbon. Arizona, pp. 259-264.

1601 Price, J.S., Schlotzhauer, S.M., 1999. Importance of shrinkage and compression in determining 1602 water storage changes in peat: the case of a mined peatland. Hydrol. Process. 13, 25912601.

1604 Pukienè, R., 1997. Pinewood growth dynamics in Uzpelkiu Tyrelis oligotrophic bog during the 1605 Subatlantic period. Dissertation. Vilnius Institute of Botany.

1606 Pukienè, R., 2001. Natural changes in bog vegetation reconstructed by sub-fossil tree remnant $1607 \quad$ analysis. Report.

1608 Pukienè, R., 2003. Sub-fossil oak timbers from the Mid Holocene as an evidence for Lithuanian 1609 forest history. Baltic For. 9, 71-75. 
1610 Reimer, P.J., Bard, E., Bayliss, A., Beck, J.W., Blackwell, P.G., Bronk Ramsey, C., Buck, C.E., 1611 Edwards, R.L., Friedrich, M., Grootes, P.M., Guilderson, T.P., Haflidason, H., Hajdas, I., 1612 Hatté, C., Heaton, T.J., Hoffman, D.L., Hogg, A.G., Hughen, K.A., Kaiser, K.F., Kromer, 1613 B., Manning, S.W., Niu, M., Reimer, R.W., Richards, D.A., Scott, M., Southon, J.R., Staff, 1614 R.A., Turney, C.S.M., van der Plicht, J., 2013. IntCal13 and Marine13 radiocarbon age 1615 calibration curves 0-50,000 years cal BP. Radiocarbon 55, $1869-1887$.

1616 Renssen, H., Seppä, H., Heiri, O., Fichefet, T., Goosse, H., Roche, D.M., 2009. The spatial and 1617 temporal complexity of the Holocene thermal maximum. Nat. Geosci. 2, 411-414.

1618 Roland, T.P., Caseldine, C.J., Charman, D.J., Turney, C.S.M., Amesbury, M.J., 2014. Was there 1619 a '4.2 ka event' in Great Britain and Ireland? Evidence from the peatland record. Quat. Sci. $1620 \quad$ Rev. 83, 11-27.

1621 Roland, T.P., Daley, T.J., Caseldine, C.J., Charman, D.J., Turney, C.S.M., Amesbury, M.J., 1622 Thompson, G.J., Woodley, E.J., 2015. The 5.2 ka climate event: Evidence from stable 1623 isotope and multi-proxy palaeoecological peatland records in Ireland. Quat. Sci. Rev. 124, $1624 \quad 209-223$.

1625 Rundgren, M., 2008. Stratigraphy of peatlands in central and northern Sweden: evidence of 1626 Holocene climatic changes and peat accumulation. GFF 130, 95-107.

1627 Rydin, H., Jeglum, J.K., 2006. The Biology of peatlands. Oxford University Press.

1628 Sacchi, C.F., Price, P., 1992. The Relative Roles of Abiotic and Biotic Factors in Seedling 1629 Demography of Arroyo Willow (Salix lasiolepis: Salicaceae). Am. J. Bot. 79, 395-405.

1630 Sass-Klaassen, U. 2004. Exploring oaks in modern wetland woods in Europe to trace the climate 1631 signal in tree-ring series of sub-fossil bog oaks In: Jansma E, Bräuning A, Gärtner H, 1632 Schleser G (eds.) TRACE - Tree Rings in Archaeology, Climatology and Ecology 2, 67-72. 
1633 Sass-Klaassen, U., Poole, I., Wils, T., Helle, G., Schleser, G.H., van Bergen, P.F., 2005. Carbon 1634 and oxygen isotope dendrochronology in sub-fossil bog oak tree rings -a preliminary study. 1635 IAWA J. 26, 121-136.

1636 Sass-Klaassen, U., Hanraets, E., 2006. Woodlands of the past - the excavation of wetland woods 1637 at Zwolle-Stadshagen (the Netherlands): growth pattern and population dynamics of oak 1638 and ash. Neth. J. Geosci. 85, 61-71.

1639 Scharnweber T., Couwenberg J., Heinrich I., Wilmking M., 2015. New insights for the 1640 interpretation of ancient bog oak chronologies? Reactions of oak (Quercus robur L.) to a 1641 sudden peatland rewetting. Palaeogeogr. Palaeocl. 417, 534-543.

1642 Schouwenaars, J.M., 1988. The impact of water management upon groundwater fluctuations in a 1643 disturbed bog relict. Agricultural Water Management 14, 439-449.

1644 Seneviratne, S.I., Corti, T., Davin, E.L., Hirschi, M., Jaeger, E.B., Lehner, I., Orlowsky, B., 1645 Teuling. A.J., 2010. Investigating soil moisture-climate interactions in a changing climate: 1646 A review. Earth-Sci. Rev. 99, 125-161.

1647 Seppä, H., Hammarlund, D., Antonsson, K., 2005. Low- and high-frequency changes of 1648 temperature and effective humidity during the Holocene in south central Sweden: 1649 implications for atmospheric and oceanic forcing of climate. Clim. Dynam. 25, 285-297.

1650 Sernander, R., 1890. Om förekomsten af subfossila stubbar på svenska insjöars botten. Botaniska $1651 \quad$ Notiser 1890, 10-20.

1652 Sernander, R. 1893. Litorinatidens klimat och vegetation. Geologiska Föreningens i Stockholm $1653 \quad$ Förhandlingar 15, 345-377.

1654 Shukla, J., Mintz, Y., 1982. The influence of land-surface evapotranspiration on the Earth's 1655 climate. Science 215, 1498-1501. 
1656 Smiljanić, M., Seo, J-W., Läänelaid, A., van der Maaten-Theunissen, M., Stajić, B., Wilmking, 1657 M., 2014. Peatland pines as a proxy for water table fluctuations: Disentangling tree growth, 1658 hydrology and possible human influence. Sci. Total Envron. 500-501, 52-63.

1659 Smith, A.G., Pilcher, J.R., Baillie, M.G.L., Hillam, J., Pearson, G.W., 1972. Dendrochronological 1660 work in progress in Belfast; the prospects for an Irish post-glacial tree-ring sequence. 1661 Proceedings of the 8th international conference on radiocarbon dating 1, 92-96.

1662 Smith, A.G., Pilcher, J.R. 1973. Radiocarbon dates and vegetation history of the British Isles. $1663 \quad$ New Phytol. 72, 903-914.

1664 Smith, R.I.L., Clymo, R.S., 1984. An extraordinary peat-forming community on the Falkland 1665 Islands. Nature 309, 617-620.

1666 Smith, B., Wårlind, D., Arneth, A., Hickler, T., Leadley, P., Siltberg, J., Zaehle, S., 2014. 1667 Implications of incorporating $\mathrm{N}$ cycling and $\mathrm{N}$ limitations on primary production in an 1668 individual-based dynamic vegetation model. Biogeosciences 11, 2027-2054. 1669 doi:10.5194/bg-11-2027-2014.

1670 Snowball, I.F., Korhola, A., Briffa, K.R., Koc, N., 2004. Holocene climate dynamics in 1671 Fennoscandia and the North Atlantic, in: Battarbee, R.W., Gasse, F., Stickley, C.E., (Eds.), 1672 Past climate variability through Europe and Africa. Springer, Dordrecht, pp. 465-494.

1673 Sohar, K., Kalm, V., 2008. A 12.8-ka-long palaeoenvironmental record revealed by subfossil 1674 ostracod data from lacustrine freshwater tufa in Lake Sinijärv, northern Estonia. J. 1675 Paleolimnol. 40, 809-821.

1676 Spurk, M., Leuschner, H.H., Baillie, M.G.L., Briffa, K.R., Friedrich, M., 2002. Depositional 1677 frequency of German subfossil oaks: climatically and non-climatically induced fluctuations 1678 in the Holocene. Holocene 12. 707-715. 
1679 Steenstrup, J.J.S., 1842. Geognostisk-geologisk Undersøgelse af Skov- moserne Vidnesdam og 1680 Lillemose i det nordlige Sjælland, led- saget af sammenlignende Bemærkninger hentede fra 1681 Danmarks Skov-, Kjær og Lyngmoser i Almindelighed, Det Kongelige Danske 1682 Videnskabernes Selskabs Naturvidenskabelige og Mathematiske Afhandlinger, 9, 17-120.

1683 Stoffel, M., Bollschweiler, M, 2008. Tree-ring analysis in natural hazards research - an overview. 1684 Nat. Hazard. Earth Sys. 8, 187-202.

1685 Stoffel, M., Corona, C., Ballesteros Canovas, J.A., Bodoque del Pozo, J.M., 2013. Dating and 1686 quantification of erosion processes based on exposed roots. Earth-Sci. Rev. 123, 18-34.

1687 Stoffel, M., Khodri, M., Corona, C., Guillet, S., Poulain, V., Bekki, S., Guiot, J., Luckman, B.H., 1688 Oppenheimer, C., Lebas, N., Beniston, M., Masson-Delmotte, V., 2015. Estimates of volcanic-induced cooling in the Northern Hemisphere over the past 1,500 years. Nat. Geosci. doi:10.1038/NGEO2526.

1691 Strakova, P., Penttila, T., Laine, J., 2012. Disentangling direct and indirect effects of water table 1692 drawdown on above- and belowground plant litter decomposition: consequences for accumulation of organic matter in boreal peatlands. Glob. Change Biol. 18, 322-335.

1694 Swindles, G.T., Plunkett, G., 2010. Testing the palaeoclimatic significance of the Northern Irish 1695 bog oak record. Holocene 20, 155-159.

1696 Swindles, G.T., Lawson, I.T., Matthews, I.P., Blaauw, M., Daley, T.J., Charman, D.J., Roland, 1697 T.P., Plunkett, G., Schettler, G.G., Benjamin, R., Turner, T.E., Rea, H.A., Roe, H.M., 1698 Amesbury, M.J., Chambers, F.M., Holmes, J., Mitchell, F.J.G., Blackford, J., Blundell, A., 1699 Branch, N., Holmes, J., Langdon, P., McCarroll, J., McDermott, F., Oksanen, P.O., 1700 Pritchard, O., Stastney, P., Stefanini, B., Young, D., Wheeler, J., Becker, K., Armit, I. 2013. 1701 Centennial-scale climate change in Ireland during the Holocene. Earth-Sci. Rev. 126, 3001702 320 http://dx.doi.org/10.1016/j.earscirev.2013.08.012 
1703 Tessier, L., de Beaulieu, J.-L., Couteaux, M., Edouard. J.-L., Ponel, P., Rolando, C., Thinon, M., 1704 Thomas, A., Tobolski, K., 1993. Holocene palaeoenvironments at the timberline in the $1705 \quad$ French Alps - a multidisciplinary approach. Boreas 22, 244-254.

1706 Torbenson, M.C.A., Plunkett, G., Brown, D.M., Pilcher, J.R., Leuschner, H.H., 2015. 1707 Asynchrony in key Holocene chronologies: Evidence from Irish bog pines. Geology 43, $1708 \quad$ 799-802. doi:10.1130/G36914.1

1709 Turney, C., Baillie, M., Clemens, S., Brown, D., Palmer, J., Pilcher, J., Reimer, P., Leuschner, 1710 H.H., 2005. Testing solar forcing of pervasive Holocene climate cycles. J. Quat. Sci. 20, $1711 \quad 511-518$.

1712 Turney, C.S.M., Baillie, M., Palmer, J., Brown, D., 2006. Holocene climatic change and past 1713 Irish societal response. J. Archaeol. Sci. 33, 34-38.

1714 Tylmann, W., Zolitschka, B., Enters, D., Ohlendorf, C., 2013. Laminated lake sediments in 1715 northeast Poland: distribution, preconditions for formation and potential for 1716 paleoenvironmental investigation. J. Paleolimnol. 50, 487-503.

1717 van Breemen, N., 1995. How Sphagnum bogs down other plants. Trends in Ecology and 1718 Evolution, 10, 270-275. doi:10.1016/0169-5347(95)90007-1.

1719 van Geel, B. 1978. A paleoecological study of holocene peat bog sections in Germany and the 1720 Netherlands based on the analysis of the pollen spores and macroscopic and microscopic 1721 remains of fungi algae cormophytes and animals. Review of Palaeobotany and Palynology $1722 \quad 25,1-120$.

1723 van Geel, B., Buurman, J., Waterbolk, H.T., 1996. Archaeological and palaeoecological 1724 indications for an abrupt climate change in The Netherlands and evidence for climatological 1725 teleconnections around 2650 BP. J. Quat. Sci. 11, 451-460. 
1726 van Geel, B., Heijnis, H., Charman, D.J., Thompson, G., Engels, S., 2014. Bog burst in the 1727 eastern Netherlands triggered by the 2.8 kyr BP climate event. Holocene 24, 1465-1477.

1728 Vaupell, C., 1851. De nordsjællandske Skovmoser. En botaniskmikroskopisk Undersøgelse af de 1729 Plantedele, som danne Tørven, og af de Levninger af Fortidens Skove, der ere bevarede i 1730 nogle nordsjællandske Skovmoser, C.A. Reitzel, Kjøbenhavn.

1731 Veski, S., Seppä, H., Ojala, A.E.K., 2004. Cold event at 8200 yr B.P. recorded annually 1732 laminated lake sediments in eastern Europe. Geology 32, 681-684.

1733 Vinther, B.M., Clausen, H.B., Johnsen, S.J., Rasmussen, S.O., Andersen, K.K., Buchardt, S.L., 1734 Dahl-Jensen, D., Seierstad, I.K., Siggaard-Andersen, M.-L., Steffensen, J.P., Svensson, 1735 A.M., Olsen, J., Heinemeier J., 2006. A synchronized dating of three Greenland ice cores 1736 throughout the Holocene. J. Geophys. Res. 111, doi:10.1029/2005JD006921.

1737 Vitas, A., Erlickytë, R., 2007. Influence of droughts to the radial growth of Scots pine (Pinus 1738 sylvestris L.) at different site conditions. Baltic For. 13, 10-16.

1739 Vitas, A., 2009. Dendrochronological analysis of subossil Fraxinus and Quercus wood excavated 1740 from the Kegai mire in Lithuania. Baltic For. 15, 41-47.

1741 Vitas, A., 2010. Dendrochronological analysis of subfossil Fraxinus from the middle and late 1742 Holocene period in Lithuania. Tree-Ring Res. 66, 83-92.

1743 von Post, L., 1924. Ur de sydsvenska skogarnas regionala historia underpost-arktis tid. 1744 Geologiska Föreningen Förhandlingar 46, 83-128.

1745 von Post, L., 1930. Die postarktische Geschichte der europäischen Wälder nach den vorliegenden 1746 Pollendiagrammen. Meddelanden från Stockholms Högskolas Geologiska Institut 16, 1-27. 1747 Waddington, J.M., Morris, P.J., Kettridge, N., Granath, G., Thompson, D.K., Moore, P.A., 2014. 1748 Hydrological feedbacks in northern peatlands. Ecohydrology, doi:10.1002/eco.1493. 
1749 Walker, D. 1970. Direction and rate of change in some British postglacial hydroseres. Studies in 1750 the Vegetation History of the British Isles, (Eds.), Walker, D., West, R.G., Cambridge 1751 University Press, Cambridge, pp. 117-139.

1752 Walker M., Berkelhammer M., Björck S., Cwynar L., Fisher D., Long A., Newnham J.L.R., 1753 Rasmussen S., Weiss H., 2012. Formal subdivision of the Holocene Series/Epoch: a 1754 discussion paper by a working group of INTIMATE (integration of ice-core, marine and 1755 terrestrial records) and the subcommission on Quaternary stratigraphy (international 1756 commission on stratigraphy). J. Quat. Sci., 649-659.

1757 Wania, R., Ross, I., Prentice, I.C., 2009. Integrating peatlands and permafrost into a dynamic 1758

1759

1760 global vegetation model: 1. Evaluation and sensitivity of physical land surface processes. Glob. Biogeo. Cyc. 23. doi:10.1029/2008GB003412.

Wania, R., Ross, I., Prentice, I.C., 2010. Implementation and evaluation of a new methane model within a dynamic global vegetation model: LPJ-WHyMe v1.3.1. Geosci. Model Dev. 3, $565-584$.

1763 Wanner, H., Beer, J., Bütikofer, J., Crowley, T.J., Cubasch, U., Flückiger, J., Goosse, H., 1764 Grosjean, M., Joos, F., Kaplan, J.O., Küttel, M., Müller, S.A., Prentice, O.C., Solomina, O., 1765 Stocker, T.F., Tarasov, P., Wagner, M., Widmann, M., 2008. Mid- to Late Holocene climate change: an overview. Quat. Sci. Rev. 27, 1791-1828.

Wanner, H., Solomina, O., Grosjean, M., Ritz, S.P., Jetel, M., 2011. Structure and origin of Holocene cold events. Quat. Sci. Rev. 30, 3109-3123.

Ward, R.G.W., Haggart, B.A., Bridge, M.C., 1987. Dendrochronological studies of bog pine from the Rannoch Moor area, western Scotland, in: Ward, R.G.W., (Eds.), Applications of Treering Studies: Current Research in Dendrochronology and Related Subjects. British Archaeological Reports International Series 333, 215-225. 
1773 Warner, B.G., 2003. Peat, in: Encyclopedia of sediments and sedimentary rocks, (Eds.), 1774 Middleton, G.V., Kluwer Academic Publishers, Dordrecht, pp. 514-516.

1775 Weedon, J.T., Kowalchuk, G.A., Aerts, R., van Hal, J., van Logtestijn, R., Tas, N., Röling, 1776 W.F.M., van Bodegom, P.M., 2012. Summer warming accelerates sub-arctic peatlend 1777 nitrogen cycling without changing enzyme pools or microbial community structure. Glob. $1778 \quad$ Change Biol. 18, 138-150.

1779 Wigley, T.M.L., Jones, P.D., Briffa, K.R., 1987. Cross-dating methods in dendrochronology. J. $1780 \quad$ Archaeol. Sci. 14, 51-64.

1781 Wilmking, M., D'Arrigo, R., Jacoby, G., Juday, G., 2005. Divergent growth responses in 1782 circumpolar boreal forests. Geophys. Res. Lett 32, L15715. doi:10.1029/2005GLO23331.

1783 Yu, Z., 2011. Holocene carbon flux histories of the world's peatlands: global carbon-cycle 1784 implications. Holocene 21, 761-774.

1785 Yu, Z., Loisel, J., Brosseau, D.P., Beilman, D.W., Hunt, S.J., 2010. Global peatland dynamics 1786 since the Last Glacial Maximum. Geophys. Res. Lett. 37. doi:10.1029/2010GL043584.

1787 Yu, Z., Beilman, D.W., Frolking, S., MacDonald, G.M., Roulet, N.T., Camill, P., Charman D.J., 1788 2011. Peatlands and their role in the global carbon cycle. EOS 92, 97-108.

1789 Yu, Z., Loisel, J, Charman, D.J., Beilman, D.W., Camill, P., 2014. Holocene peatland carbon 1790 dynamics in the circum-Arctic region: An introduction. Holocene 24, 1021-1027.

1791 Zinke, J., Rountrey, A., Feng, M., Xie, S.P., Dissard, D., Rankenburg, K., Lough, J., McCulloch 1792 M.T. 2014. Corals record long-term Leeuwin Current variability including Ningaloo 1793 Niño/Niña since 1795. Nature Communications 5, 3607. doi:10.1038/ncomms4607. 
1799 Fig. 1. (a) Location of the main peatlands referred to in Tables 1 and 2 (Id. No. 1-81). Sites from 1800 which subfossil trees have been sampled are shown by black squares while sites from which 1801 living trees have been sampled are shown by red triangles. (b) Map over peatlands outside 1802 northwest Europe. Peat coverage is based on Montanarella et al. (2006).

1804 Fig. 2. (a) During the early Holocene, many topographic depressions were occupied by lakes in 1805 which organic layers consisting of e.g. gyttja (1) was deposited. In the shallow areas along the 1806 shores, reed or fen peat was developed (2). (b) During the mid-Holocene, relatively warm and dry 1807 conditions allowed trees to colonize many peatlands. (c) Accelerating peat growth following wet1808 shifts can often be observed as recurrence surfaces (RS) in stratigraphic records. Such 1809 hydrological changes may cause tree dying-off phases. Stumps and trunks from these trees can be 1810 preserved by the growing peat (3). (d) At present peatlands are valuable climate archives. Peat 1811 stratigraphic records (4) generate long-term information showing environmental changes, 1812 whereas tree-ring chronologies (5) can generate annually resolved information. The tree-ring 1813 chronologies (example from Edvardsson, 2016) can be developed from both living and subfossil 1814 trees (6). Tree growth is usually influenced by hydrological variations (7) related to climate (8). 1815 Moreover, climate, hydrology, and tree growth ultimately influence the carbon budget (9) of the 1816 peatlands.

1818 Fig. 3. (a) The natural raised bog Fjällmossen (S. Sweden) is characterized by scattered 1819 populations of birch and pine trees. (b) Open water ponds at the raised bog Aukštumala 1820 (Lithuania) show how close the water table is to bog surface and the root systems of the pine 
1821 trees. (c) Peatland pines growing at Saxnäs Mosse, Sweden. (d) A till hummock in

1822 Hästhultsmossen (S. Sweden) generates stable and dry conditions favoring colonization of trees.

1823 The area surrounding the mineral soil hummock, however, is relatively wet, unstable and

1824 supports significantly smaller pine trees even though the trees are of same age.

1825

1826 Fig. 4. (a) Several meters of peat have been harvested at the Rèkyva peat mining area (Lithuania)

1827 with the result that subfossil trees preserved in peat have been exposed. (b) Tree horizon at the

1828 Viss Mosse peatland (Sweden; Fig. 1, site 23) containing in situ pine stumps. These trees were

1829 growing at the bog surface between 7200 and 6500 years BP. (c) Field sampling of a c. 6000-

1830 years old pine tree at Hällarydsmossen (Sweden; Fig. 1, site 22b). (d) To enable continued peat

1831 mining, tree trunks and stumps are often stored in piles surrounding the peat mining area

1832 (Hällarydsmossen).

1833

1834 Fig. 5. Cross-sections and annual growth rings from subfossil trees exhibit different growth

1835 patterns and characteristics. (a) Two cross-sections from Scots pine (Pinus sylvestris L.)

1836 excavated at Viss Mosse (Fig. 1, site 23). The left hand sample contains a complete ring sequence

1837 from pith to bark corresponding to 5078-4970 BCE (7027-6919 BP). The right hand sample has

1838 degraded after death. The growth rings correspond to the period 4872-4716 BCE (6821-6665

1839 BP), but approximately 50-70 rings towards the center and another 10-20 of the outermost rings

1840 are expected but have eroded away. (b) Fire scar dated to 4420 BCE (6369 BP). (c) Abrupt

1841 growth depression visible in a pine tree from the peatland Åbuamossen (Fig. 1, site 24). The

1842 growth depression most likely resulted from a period of extremely wet conditions between 1288

1843 and $1270 \mathrm{BCE}(3237-3219 \mathrm{BP})$ and is visible in all dated trees growing at the peatland. (d) Tree-

1844 ring sequence from a subfossil oak (Quercus robur L.). (e) Eccentric pine-stem cross-section 
1845 characteristic for trees growing on unstable soils. The innermost 70 annual rings are circular,

1846 whereas about $4070 \mathrm{BCE}(6020 \mathrm{BP})$ unstable conditions are evident having forced the tree to

1847 form reaction wood. (f) About 70 narrow annual rings (inside the circle) around the pith,

1848 indicating unfavourable conditions during establishment.

1850 Fig. 6. Significant cross-dating statistics between continental and Irish peatland and oak 1851 chronologies have been described by Pilcher et al. (1984) and Leuschner et al. (2002; arrow a).

1852 German peatland-oaks also cross-date oaks from River Main (Friedrich et al., 2004, arrow b), the 1853 Netherlands (Sass-Klaassen and Hanraets, 2006; arrow c), Denmark (unpublished, see Fig. 7;

1854 arrow d), and Swedish pine (Edvardsson, 2013; arrow e), whereas the Irish chronologies (oak and 1855 pine) cross-date with the material from Great Britain and Scotland (e.g. Boswik and Woodhouse, 1856 2002; arrow f). Some of the Danish and Swedish oak chronologies also cross-date (Edvardsson et

1857 al., 2014b; arrow g). Furthermore, the Swedish and German pine chronologies generated strong 1858 cross-dating statistics (Edvardsson et al., 2012a; arrow e). Attempts to cross-date Baltic pine 1859 chronologies using material from Germany and Sweden have, however, failed (Edvardsson et al., 1860 2016a; dashed arrows h). Tests to cross-date south Swedish pine chronologies with peatland pines 1861 described by Gunnarson (1999; dashed arrow i) and subfossil mineral soil pines from Torneträsk 1862 (Grudd et al., 2002; dashed arrow j) failed as well. By contrast, the north Swedish and Finnish 1863 chronologies (Helama et al., 2005; arrow k) indeed cross-date well. Peat coverage is based on 1864 Montanarella et al. (2006).

1865

1866 Fig. 7. Stepwise cross-dating of tree-ring chronologies from northwest Europe. The t-values 1867 between different chronologies are presented next to the arrows. Oak chronologies are shown in 1868 black, pine in grey, and dashed lines represent historical material anchored in present. The figures 
1869 to the right correspond to the site IDs in Fig. 1 and Table 1. The River Main oak chronology (*, 1870 Friedrich et al., 2004) is also included in the figure.

1872 Fig. 8. Comparisons between tree-ring width (TRW) and meteorological records (monthly 1873 temperature and precipitation data). Sites from which both tree growth at mineral soils (MS) and 1874 peat soils (PS) could be compared are presented. The identification numbers (Id. No.) 1875 corresponds to those presented in Fig. 1 and Table 2.

1877 Fig. 9. (a-b) Examples of TRW chronologies from living trees growing at Aukštumala and 1878 Rèkyva (Edvardsson et al., 2015a). (c) Precipitation data from the meteorological station in 1879 Vilnius. (d) TRW chronologies from Buxabygds Mosse, Saxnäs Mosse and Store Mosse, Sweden 1880 (Edvardsson and Hansson, 2015). (e) Local precipitation data and (f) river discharge data. The 1881 blue bars emphasize moist periods associated with positive precipitation anomalies, grey lines 1882 represent average values. Growth depressions or trends towards narrower growth rings can often 1883 be observed during phases associated with positive precipitation/wet anomalies.

1885 Fig. 10. Main data series compared in the discussion, oak in black, pine in green, and numbers in 1886 brackets correspond to those in Table 1. (a) Irish data series, in black Irish oak replication, in 1887 green pine establishments, and cumulative radiocarbon dated pine samples (green/black squares).

1888 (b) Cumulative weighted Scottish peatland trees dated by radiocarbon and coverage of peatland 1889 pines chronologies. (c) German peatland oaks. (d) Continental and Irish oak mean-age records. 1890 (e) German pine replication and woodland phases. (f) Replication and temporal spread of oak 1891 from the Netherlands. (g) Periods covered by Danish peatland oaks. (h) Swedish pine replication 
1892 and periods covered by oak chronologies. (i) Polish pine chronologies. (j) Lithuanian pine 1893 replication as well as pine and oak coverage. (k) Pine replication from Finland. (l) Spruce 1894 coverage from Canada. (m) Dry and wet shifts highlighted in yellow and blue respectively 1895 (Wanner et al., 2011). (n) Wet shifts detected in peat bogs from northern Britain (Charman, 1896 2006). (o) Lake levels in the Baltic region (Sohar and Kalm, 2008). (p) High lake-level phases in 1897 mid-European lakes (Magny, 2004, 2013). (q) Wet shifts detected as recurrence surfaces in 1898 Swedish peat bogs (Borgmark and Wastegård, 2008). (r) In blue, temperature anomalies in 1899 relation to the average (Marcott et al., 2013) and in red, a pollen based temperature reconstruction 1900 by Heikkilä and Seppä (2008).

1901 Fig. 11. Correlation tests between dimensionless TRW indices (grey) from the peatland 1902 Čepkeliai, Lithuania and (a) water-table fluctuations (cm) in relation to the average level, (b) total 1903 annual precipitation $(\mathrm{mm})$, and (c) annual mean temperature $\left({ }^{\circ} \mathrm{C}\right)$. 
Table 1. Representation of the main studies used in this review for comparison. Study areas include Austria (AU), Canada (CA), Denmark (DK), Finland (FI), France (FR), Germany (DE), Great Britain (GB), Ireland (IE), Italy (IT), Lithuania (LT), the Netherlands (NL), Poland (PL), Sweden (SE), and Switzerland (CH). Tree species presented are Alder (A), Ash (F), Larch (La), Oak (Q), Pine (P), and Spruce (Pi), and what context the material originates from, bogs/peatlands (b), mainly bogs/peatlands (m) and partly bogs/peatlands (p).

\begin{tabular}{|c|c|c|c|}
\hline Id. No. and References & $\begin{array}{l}\text { Country / } \\
\text { Latitude, Longitude }\end{array}$ & $\begin{array}{l}\text { Species / } \\
(\mathbf{b}, \mathbf{m}, \mathbf{p})\end{array}$ & Main time span \\
\hline 1. Achterberg et al. (2015) & $\mathrm{DE} / 52^{\circ} 50^{\prime} \mathrm{N}, 9^{\circ} 50^{\prime} \mathrm{E} *$ & $\mathrm{P}(\mathrm{b})$ & 4629 BCE - CE 502 \\
\hline 2. Achterberg et al. (2016) & $\mathrm{DE} / 52^{\circ} 50^{\prime} \mathrm{N}, 9^{\circ} 50^{\prime} \mathrm{E} *$ & $\mathrm{P}, \mathrm{Q}(\mathrm{b})$ & 6703 BCE - CE 931 \\
\hline 3. Arseneaut \& Payette (1997) & $\mathrm{CA} / 57^{\circ} 44^{\prime} \mathrm{N}, 76^{\circ} 10^{\prime} \mathrm{W}$ & $\mathrm{Pi}(\mathrm{b})$ & $500 \mathrm{BCE}$ - present \\
\hline 4. Baillie (1973) & $\mathrm{IE} / 54^{\circ} 50^{\prime} \mathrm{N}, 6^{\circ} 50^{\prime} \mathrm{W} *$ & $Q(b)$ & $5000-1380 \mathrm{CE}$ \\
\hline 5. Baillie (1977) & $\mathrm{IE} / 54^{\circ} 50^{\prime} \mathrm{N}, 6^{\circ} 50^{\prime} \mathrm{W} *$ & $Q(b)$ & 5000-1001 CE \\
\hline 6. Baillie et al. (1983) & $\mathrm{IE} / 54^{\circ} 50^{\prime} \mathrm{N}, 6^{\circ} 50^{\prime} \mathrm{W} *$ & $Q(b)$ & $5000-1000 \mathrm{BCE}$ \\
\hline 7. Baillie \& Brown (1988) & $\mathrm{IE} / 54^{\circ} 50^{\prime} \mathrm{N}, 6^{\circ} 50^{\prime} \mathrm{W} *$ & $Q(b)$ & $5300-200 \mathrm{BCE}$ \\
\hline 8. Barniak et al. (2014) & $\mathrm{PL} / 54^{\circ} 15^{\prime} \mathrm{N}, 19^{\circ} 44^{\prime} \mathrm{E}$ & $\mathrm{P}(\mathrm{b})$ & $940-460 \mathrm{BCE} * *$ \\
\hline 9. Bauerochse et al. (2015) & $\mathrm{DE} / 52^{\circ} 50^{\prime} \mathrm{N}, 9^{\circ} 50^{\prime} \mathrm{E} *$ & $\mathrm{P}, \mathrm{Q}(\mathrm{b})$ & 2600-1500 BCE \\
\hline 10. Boswick \& Whitehouse (2002) & $\mathrm{GB} / 53^{\circ} 32^{\prime} \mathrm{N}, 0^{\circ} 57^{\prime} \mathrm{W}$ & $P(b)$ & 2921-2445 BCE \\
\hline 11. Bridge et al. (1990) & $\mathrm{GB} / 56^{\circ} 52^{\prime} \mathrm{N}, 4^{\circ} 32^{\prime} \mathrm{W} *$ & $\mathrm{P}(\mathrm{b})$ & $5900-1200 \mathrm{BCE} * * *$ \\
\hline 12. Brown et al. (1986) & $\mathrm{IE} / 54^{\circ} 50^{\prime} \mathrm{N}, 6^{\circ} 50^{\prime} \mathrm{W} *$ & $Q(b)$ & $5300-200 \mathrm{BCE}$ \\
\hline 13. Brown \& Baillie (1992) & $\mathrm{IE} / 54^{\circ} 50^{\prime} \mathrm{N}, 6^{\circ} 50^{\prime} \mathrm{W} *$ & $\mathrm{P}, \mathrm{Q}(\mathrm{b})$ & $3600-2600 \mathrm{BCE}$ \\
\hline 14. Brown \& Baillie (2012) & $\mathrm{IE} / 54^{\circ} 50^{\prime} \mathrm{N}, 6^{\circ} 50^{\prime} \mathrm{W} *$ & $\mathrm{Q}(\mathrm{m})$ & $5200 \mathrm{BCE}$ - present \\
\hline 15. Chambers et al. (1997) & $\mathrm{GB} / 53^{\circ} 40^{\prime} \mathrm{N}, 0^{\circ} 53^{\prime} \mathrm{W}$ & $\mathrm{P}(\mathrm{b})$ & 2900-2400 BCE \\
\hline 16. Charman (2010) & $\mathrm{IE} / 54^{\circ} 60^{\prime} \mathrm{N}, 6^{\circ} 40^{\prime} \mathrm{W} *$ & $Q(b)$ & $5000 \mathrm{BCE}$ - present \\
\hline 17. Christensen (2007) & $\mathrm{DK} / 56^{\circ} 30^{\prime} \mathrm{N}, 9^{\circ} 50^{\prime} \mathrm{E} *$ & $\mathrm{Q}(\mathrm{m})$ & $6000-200 \mathrm{BCE}$ \\
\hline 18. Delorme et al. (1981) & $\mathrm{DE} / 52^{\circ} 50^{\prime} \mathrm{N}, 9^{\circ} 50^{\prime} \mathrm{E} *$ & $\mathrm{Q}(\mathrm{b})$ & $350-150 \mathrm{BCE} * *$ \\
\hline 19. Eckstein et al. (2009) & $\mathrm{DE} / 52^{\circ} 50^{\prime} \mathrm{N}, 9^{\circ} 50^{\prime} \mathrm{E} *$ & $\mathrm{P}(\mathrm{b})$ & $5600-2200 \mathrm{BCE}$ \\
\hline 20. Eckstein et al. (2010) & $\mathrm{DE} / 52^{\circ} 44^{\prime} \mathrm{N}, 8^{\circ} 17^{\prime} \mathrm{E}$ & $\mathrm{P}, \mathrm{Q}(\mathrm{b})$ & 2450-2050 BCE \\
\hline 21. Eckstein et al. (2011) & $\mathrm{DE} / 52^{\circ} 70^{\prime} \mathrm{N}, 9^{\circ} 00^{\prime} \mathrm{E} *$ & $\mathrm{P}(\mathrm{b})$ & $6500-1200 \mathrm{BCE}$ \\
\hline \multirow[t]{2}{*}{ 22. Edvardsson et al. (2012a) } & $\mathrm{SE} / 55^{\circ} 51^{\prime} \mathrm{N}, 13^{\circ} 49^{\prime} \mathrm{E}$ & $\mathrm{P}(\mathrm{b})$ & 5219-4574 BCE \\
\hline & $\mathrm{SE} / 57^{\circ} 20^{\prime} \mathrm{N}, 14^{\circ} 35^{\prime} \mathrm{E}$ & $P(b)$ & 4839-3728 BCE \\
\hline 23. Edvardsson et al. (2012b) & $\mathrm{SE} / 55^{\circ} 51^{\prime} \mathrm{N}, 13^{\circ} 49^{\prime} \mathrm{E}$ & $\mathrm{P}(\mathrm{b})$ & $6100-4600 \mathrm{BCE}$ \\
\hline 24. Edvardsson et al (2014a) & $\mathrm{SE} / 56^{\circ} 00^{\prime} \mathrm{N}, 14^{\circ} 00^{\prime} \mathrm{E} *$ & $\mathrm{P}(\mathrm{b})$ & $4540-4460,1320-1240 \mathrm{BCE}$ \\
\hline 25. Edvardsson et al. (2014b) & $\mathrm{SE} / 55^{\circ} 51^{\prime} \mathrm{N}, 13^{\circ} 49^{\prime} \mathrm{E}$ & $\mathrm{P}, \mathrm{Q}, \mathrm{A}, \mathrm{F}(\mathrm{b})$ & $4500-1000 \mathrm{BCE} * *$ \\
\hline 26. Edvardsson (2016) & $\mathrm{SE} / 56^{\circ} 19^{\prime} \mathrm{N}, 13^{\circ} 55^{\prime} \mathrm{E}$ & $\mathrm{P}(\mathrm{b})$ & 2667-1108 BCE \\
\hline 27. Edvardsson et al. (2016a) & $\mathrm{LT} / 55^{\circ} 30^{\prime} \mathrm{N}, 23^{\circ} 50^{\prime} \mathrm{E} *$ & $\mathrm{P}(\mathrm{b})$ & $4000 \mathrm{BCE}-\mathrm{CE} 900 *$ \\
\hline 28. Gear \& Huntley (1991) & $\mathrm{GB} / 58^{\circ} 24^{\prime} \mathrm{N}, 4^{\circ} 3^{\prime} \mathrm{W}$ & $\mathrm{P}(\mathrm{b})$ & 2450-1900 BCE ** \\
\hline 29. Grudd et al. (2000) & $\mathrm{SE} / 59^{\circ} 08^{\prime} \mathrm{N}, 17^{\circ} 55^{\prime} \mathrm{E}$ & $\mathrm{P}(\mathrm{b})$ & $1700-1500 \mathrm{BCE} * *$ \\
\hline 30. Gunnarson (1999) & $\mathrm{SE} / 59^{\circ} 08^{\prime} \mathrm{N}, 17^{\circ} 55^{\prime} \mathrm{E}$ & $\mathrm{P}(\mathrm{b})$ & $1686-1483 \pm 23 \mathrm{BCE} * *$ \\
\hline 31. Gunnarson (2008) & $\mathrm{SE} / 63^{\circ} 16^{\prime} \mathrm{N}, 12^{\circ} 31^{\prime} \mathrm{E}$ & $P(p)$ & $5000-2000 \mathrm{BCE} * *$ \\
\hline 32. Hall et al. (1994) & $\mathrm{IE} / 55^{\circ} 05^{\prime} \mathrm{N}, 6^{\circ} 34^{\prime} \mathrm{W}$ & $\mathrm{P}, \mathrm{Q}(\mathrm{b})$ & $6000-0 \mathrm{BCE} * *$ \\
\hline 33. Helama et al. (2004) & $\mathrm{FI} / 67^{\circ} 50^{\prime} \mathrm{N}, 26^{\circ} 25^{\prime} \mathrm{E} *$ & $P(p)$ & $5600 \mathrm{BCE}-$ present \\
\hline 34. Jansma (1996) & $\mathrm{NL} / 50^{\circ} 83^{\prime} \mathrm{N}, 5^{\circ} 57^{\prime} \mathrm{E}$ & $\mathrm{Q}(\mathrm{p})$ & $2258-1141 \mathrm{BCE}$ \\
\hline 35. Lageard et al. (1999) & $\mathrm{GB} / 53^{\circ} 40^{\prime} \mathrm{N}, 2^{\circ} 20^{\prime} \mathrm{W} *$ & $\mathrm{P}, \mathrm{Q}(\mathrm{b})$ & 3520-2462BCE **, 3228-1891 BCE \\
\hline 36. Lageard et al. (2000) & $\mathrm{GB} / 53^{\circ} 40^{\prime} \mathrm{N}, 2^{\circ} 20^{\prime} \mathrm{W} *$ & $\mathrm{P}(\mathrm{b})$ & $2881-2639$ BCE \\
\hline 37. Leuschner et al. (1987) & $\mathrm{DE} / 52^{\circ} 40^{\prime} \mathrm{N}, 8^{\circ} 20^{\prime} \mathrm{E} *$ & $Q(b)$ & $6000 \mathrm{BCE}-500 \mathrm{CE}$ \\
\hline 38. Leuschner \& Delorme (1988) & $\mathrm{DE} / 52^{\circ} 40^{\prime} \mathrm{N}, 8^{\circ} 20^{\prime} \mathrm{E}^{*}$ & $\mathrm{Q}(\mathrm{m})$ & $6225 \mathrm{BCE}-$ present \\
\hline 39. Leuschner (1992) & $\mathrm{DE} / 52^{\circ} 40^{\prime} \mathrm{N}, 8^{\circ} 20^{\prime} \mathrm{E}^{*}$ & $Q(b)$ & 6000 BCE-500 CE \\
\hline 40. Leuschner et al. (2000) & $\mathrm{DE}, \mathrm{NL} *$ & $Q(b)$ & $\begin{array}{l}6000 \text { BCE-500 CE (GE), } \\
6000-4500 \text { BCE, } 3000 \text { BCE-500 CE }\end{array}$ \\
\hline 41. Leuschner et al. (2002) & $\mathrm{DE}, \mathrm{IE}, \mathrm{NL} *$ & $\mathrm{Q}(\mathrm{b})$ & 6069 BCE-1596 CE \\
\hline 42. Leuschner et al. (2007) & $\mathrm{DE} / 52^{\circ} 27^{\prime} \mathrm{N}, 8^{\circ} 10^{\prime} \mathrm{E}$ & $\mathrm{P}(\mathrm{b})$ & $3050-2700 \mathrm{BCE}$ \\
\hline 43. McGeever \& Mitchell (2015) & $\mathrm{IE} / 53^{\circ} 00^{\prime} \mathrm{N}, 7^{\circ} 00^{\prime} \mathrm{W} *$ & $\mathrm{P}(\mathrm{b})$ & $6000 \mathrm{BCE}-1000 \mathrm{CE} * * *$ \\
\hline 44. Moir et al. (2010) & $\mathrm{GB} / 58^{\circ} 90^{\prime} \mathrm{N}, 4^{\circ} 30^{\prime} \mathrm{W} *$ & $\mathrm{P}(\mathrm{b})$ & $3200-3000 \mathrm{BCE}$ \\
\hline 45. Moir $(2005,2012)$ & $\mathrm{GB} / 58^{\circ} 90^{\prime} \mathrm{N}, 4^{\circ} 30^{\prime} \mathrm{W}^{*}$ & $\mathrm{P}(\mathrm{b})$ & $3200-2800 \mathrm{BCE}$ \\
\hline 46. Munaut (1967) & $\mathrm{NL} / 52^{\circ} 60^{\prime} \mathrm{N}, 6^{\circ} 30^{\prime} \mathrm{E}$ & $\mathrm{P}(\mathrm{b})$ & $5000,4000,3000 \mathrm{BCE} * *$ \\
\hline 47. Munaut \& Casparie (1971) & $\mathrm{NL} / 52^{\circ} 60^{\prime} \mathrm{N}, 6^{\circ} 30^{\prime} \mathrm{E}$ & $\mathrm{P}(\mathrm{b})$ & $5000,4000,3000 \mathrm{BCE} * *$ \\
\hline
\end{tabular}


48. Nicolussi et al. (2005)

49. Nicolussi et al. (2009)

50. Pilcher et al. (1973)

51. Pilcher et al. (1977)

52. Pilcher et al. (1984)

54. Pilcher et al. (1996)

55. Pukienè $(1997,2001)$

57. Sass-Klassen et al. (2005)

58. Sass-Klassen \&Hanraets (2006)

59. Simard et al. (2011)

60. Tessier et al (1993)

62. Turney et al. (2005)

63. Vitas (2009)

64. Vitas (2010)

65. Ward et al. (1987)
53. Pilcher et al. (1995)

56. Pukienè (2003)

61. Torbenson et al. (2015)

\begin{tabular}{|c|c|c|}
\hline $\mathrm{AU} / 46^{\circ} 90^{\prime} \mathrm{N}, 10^{\circ} 70^{\prime} \mathrm{E} *$ & $P(p)$ & 7100-2100BCE \\
\hline $\mathrm{AU}, \mathrm{IT}, \mathrm{CH} *$ & $\mathrm{P}, \mathrm{Pi}, \mathrm{La}(\mathrm{p})$ & 7100BCE - present \\
\hline IE / $54^{\circ} 50^{\prime} \mathrm{N}, 6^{\circ} 50^{\prime} \mathrm{W} *$ & $\mathrm{Q}, \mathrm{P}(\mathrm{b})$ & $6000 \mathrm{BCE}-$ present \\
\hline $\mathrm{IE} / 54^{\circ} 50^{\prime} \mathrm{N}, 6^{\circ} 50^{\prime} \mathrm{W} *$ & $\mathrm{Q}(\mathrm{b})$ & 4000-1000 BCE \\
\hline $\mathrm{IE}, \mathrm{GB}, \mathrm{DE} *$ & $\mathrm{Q}(\mathrm{m})$ & 5218-158 BCE (present) \\
\hline $\mathrm{IE} / 54^{\circ} 60^{\prime} \mathrm{N}, 5^{\circ} 90^{\prime} \mathrm{W} *$ & $P(b)$ & $3451-2569 \mathrm{BCE}$ \\
\hline IE $/ 54^{\circ} 60^{\prime} \mathrm{N}, 6^{\circ} 50^{\prime} \mathrm{W} *$ & $\mathrm{Q}(\mathrm{m})$ & 5218-158 BCE \\
\hline $\mathrm{LT} / 56^{\circ} 05^{\prime} \mathrm{N}, 21^{\circ} 50^{\prime} \mathrm{E}$ & $\mathrm{P}(\mathrm{b})$ & 200 BCE-present** \\
\hline $\mathrm{LT} / 56^{\circ} 12^{\prime} \mathrm{N}, 24^{\circ} 44^{\prime} \mathrm{E}$ & Q (b) & $4600-4400$ ВCE** \\
\hline NL / $52^{\circ} 31^{\prime} \mathrm{N}, 6^{\circ} 02^{\prime} \mathrm{E}$ & Q (b) & 200 BCE-150 CE \\
\hline $\mathrm{NL} / 52^{\circ} 31^{\prime} \mathrm{N}, 6^{\circ} 02^{\prime} \mathrm{E}$ & $\mathrm{Q}, \mathrm{F}(\mathrm{b})$ & 600 BCE-200 CE \\
\hline $\mathrm{CA} / 48^{\circ} \mathrm{N}, 71^{\circ} \mathrm{W} *$ & Pi (b) & $3200 \mathrm{BCE} * *$ \\
\hline $\mathrm{FR} / 45^{\circ} 05^{\prime} \mathrm{N}, 5^{\circ} 92^{\prime} \mathrm{E}$ & $P(p)$ & 6000 BCE - present $* *$ \\
\hline $\mathrm{IR} / 54^{\circ} 49^{\prime} \mathrm{N}, 6^{\circ} 30^{\prime} \mathrm{W} *$ & P (b) & 6300-5600 BCE \\
\hline IE $/ 54^{\circ} 60^{\prime} \mathrm{N}, 6^{\circ} 40^{\prime} \mathrm{W} *$ & $\mathrm{Q}, \mathrm{P}(\mathrm{m})$ & $5000 \mathrm{BCE}-$ present \\
\hline $\mathrm{LT} / 55^{\circ} 50^{\prime} \mathrm{N}, 22^{\circ} 17^{\prime} \mathrm{E}$ & $\mathrm{Q}, \mathrm{F}(\mathrm{b})$ & $4700-1500 \mathrm{BCE} * *$ \\
\hline $\mathrm{LT} / 55^{\circ} 48^{\prime} \mathrm{N}, 21^{\circ} 53^{\prime} \mathrm{E}$ & $\mathrm{F}, \mathrm{A}, \mathrm{Q}, \mathrm{B}(\mathrm{b})$ & $3800-1290$ BCE ** \\
\hline $\mathrm{GB} / 56^{\circ} 40^{\prime} \mathrm{N}, 4^{\circ} 18^{\prime} \mathrm{W}$ & $\mathrm{P}(\mathrm{b})$ & 4500-1000 BCE ** \\
\hline
\end{tabular}

*Approximate coordinates as the chronology/chronologies are based on material from several study sites

**Approximate ages as the chronology/chronologies are dated by radiocarbon

***Approximate ages as of individual subfossil trees (no tree-ring chronologies) dated by radiocarbon

Table 2. Papers in which comparative studies based on peat soil and mineral soil trees have been performed. For further information, see Fig 1 and 8. Study areas include Great Britain (GB), Lithuania (LT), Poland (PL), Russia (RU), and Sweden (SE). Tree species included are Pinus sylvestris (PiSy) and Pinus sibirica (PiSi).

\begin{tabular}{|c|c|c|c|}
\hline Id. No. and References & Country / Site name & Latitude, Longitude & Species \\
\hline 66. Blanchet et al. (2016) & RU / Mukhrino & $60^{\circ} 54^{\prime} \mathrm{N}, 68^{\circ} 42^{\prime} \mathrm{E}$ & PiSy, PiSi \\
\hline 67. Cedro \& Lamentowicz (2011) & PO / Słowinskie Błoto & $54^{\circ} 21^{\prime} \mathrm{N}, 16^{\circ} 29^{\prime} \mathrm{E}$ & PiSy \\
\hline 68. Edvardsson et al. $(2015 \mathrm{a}, \mathrm{b})$ & LT / Aukštumala & $55^{\circ} 23^{\prime} \mathrm{N}, 21^{\circ} 22^{\prime} \mathrm{E}$ & PiSy \\
\hline 69. Edvardsson et al. $(2015 \mathrm{a}, \mathrm{b})$ & LT / Kerèplis & $54^{\circ} 27^{\prime} \mathrm{N}, 24^{\circ} 32^{\prime} \mathrm{E}$ & PiSy \\
\hline 70. Edvardsson et al. (2015a, b) & LT / Rėkyva & $55^{\circ} 51^{\prime} \mathrm{N}, 23^{\circ} 15^{\prime} \mathrm{E}$ & PiSy \\
\hline 71. Edvardsson \& Hansson (2015) & SE / Store Mosse & $57^{\circ} 14^{\prime} \mathrm{N}, 13^{\circ} 55^{\prime} \mathrm{E}$ & PiSy \\
\hline 72. Linderholm (2001) & SE / Lake Ånn & $63^{\circ} 15^{\prime} \mathrm{N}, 12^{\circ} 30^{\prime} \mathrm{E}$ & PiSy \\
\hline 73. Linderholm et al. (2002) & SE / Augerusjärvi & $67^{\circ} 38^{\prime} \mathrm{N}, 21^{\circ} 46^{\prime} \mathrm{E}$ & PiSy \\
\hline 74. Linderholm et al. (2002) & SE / Stortjäderberget & $54^{\circ} 32^{\prime} \mathrm{N}, 19^{\circ} 00^{\prime} \mathrm{E}$ & PiSy \\
\hline 75. Linderholm et al. (2002) & SE / Årsön & $63^{\circ} 15^{\prime} \mathrm{N}, 12^{\circ} 30^{\prime} \mathrm{E}$ & PiSy \\
\hline 76. Linderholm et al. (2002) & SE / Bredmossen & $60^{\circ} 08^{\prime} \mathrm{N}, 16^{\circ} 05^{\prime} \mathrm{E}$ & PiSy \\
\hline 77. Linderholm et al. (2002) & SE / Hanvedsmossen & $59^{\circ} 09^{\prime} \mathrm{N}, 17^{\circ} 55^{\prime} \mathrm{E}$ & PiSy \\
\hline 78. Linderholm et al. (2002) & SE / Anebymossen & $57^{\circ} 51^{\prime} \mathrm{N}, 14^{\circ} 38^{\prime} \mathrm{E}$ & PiSy \\
\hline 79. Moir et al. (2011) & GB / Eilean Subhainn & $58^{\circ} 41^{\prime} \mathrm{N}, 5^{\circ} 29^{\prime} \mathrm{W}$ & PiSy \\
\hline 80. Moir et al. (2011) & GB / Abernethy & $57^{\circ} 14^{\prime} \mathrm{N}, 3^{\circ} 40^{\prime} \mathrm{E}$ & PiSy \\
\hline 81. Edvardsson (unpublished) & LT / Čepkeliai & $54^{\circ} 07^{\prime} \mathrm{N}, 24^{\circ} 30^{\prime} \mathrm{E}$ & PiSy \\
\hline
\end{tabular}


Fig. 1

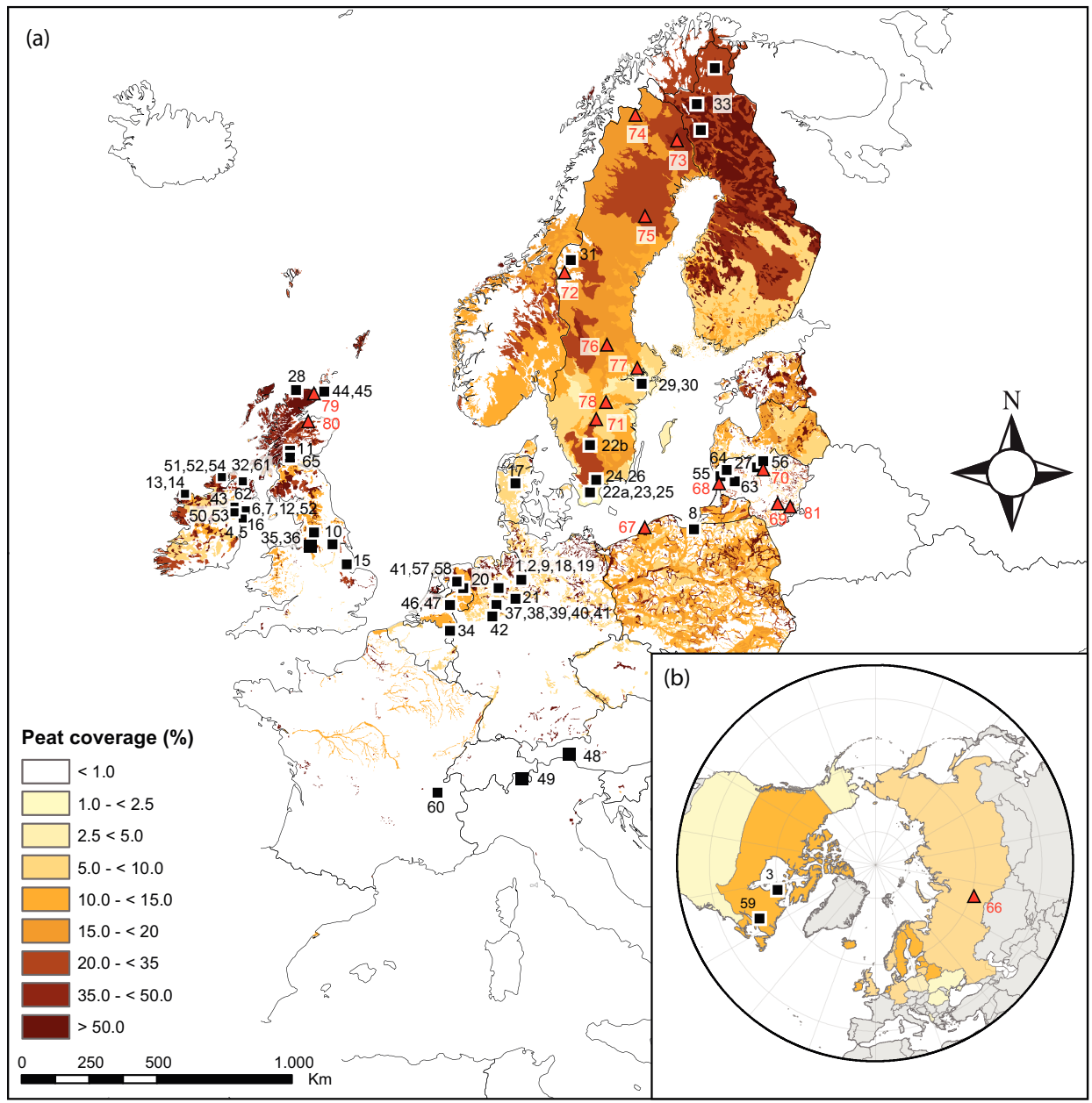


Fig. 2

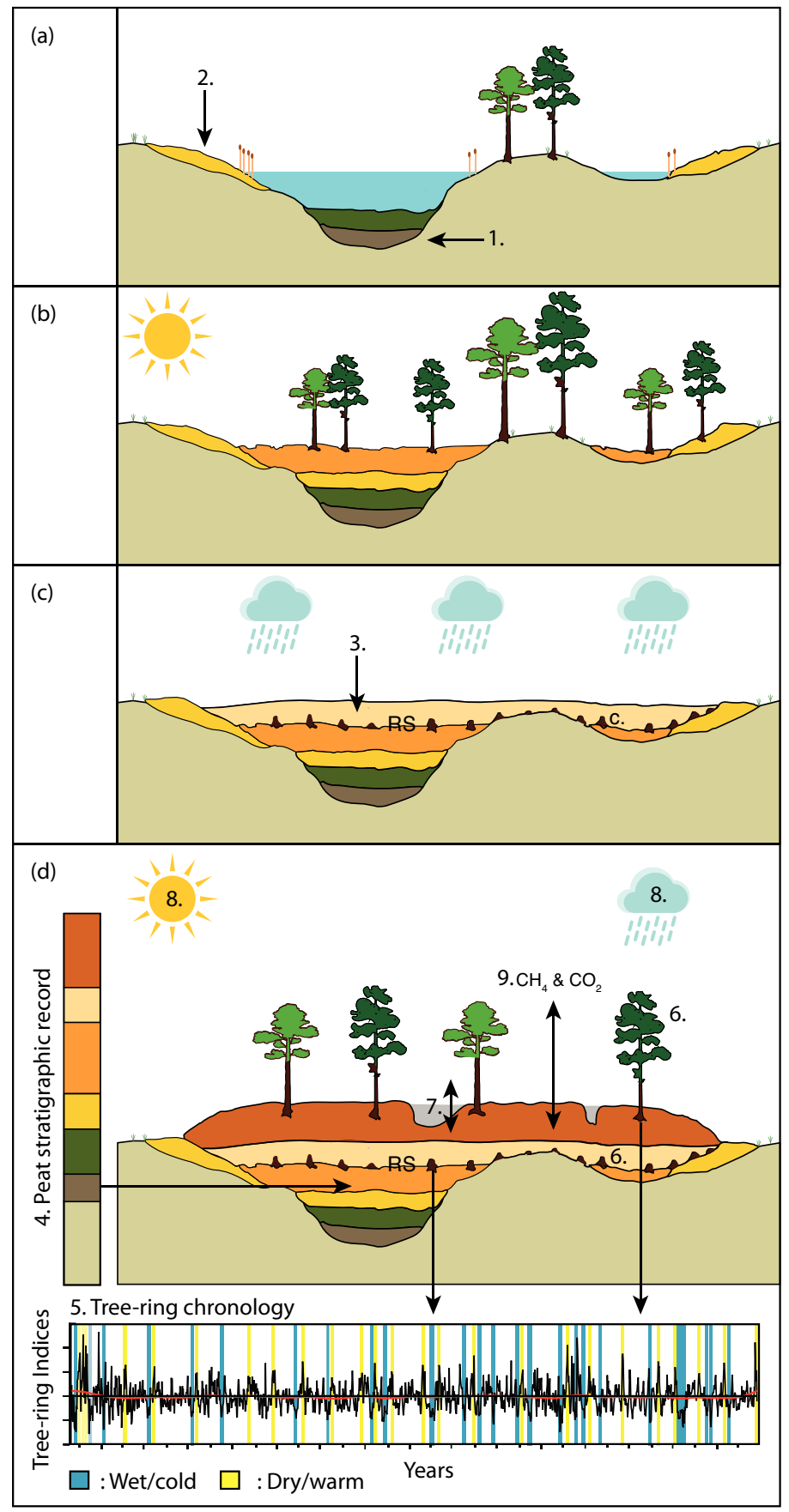


Fig. 3

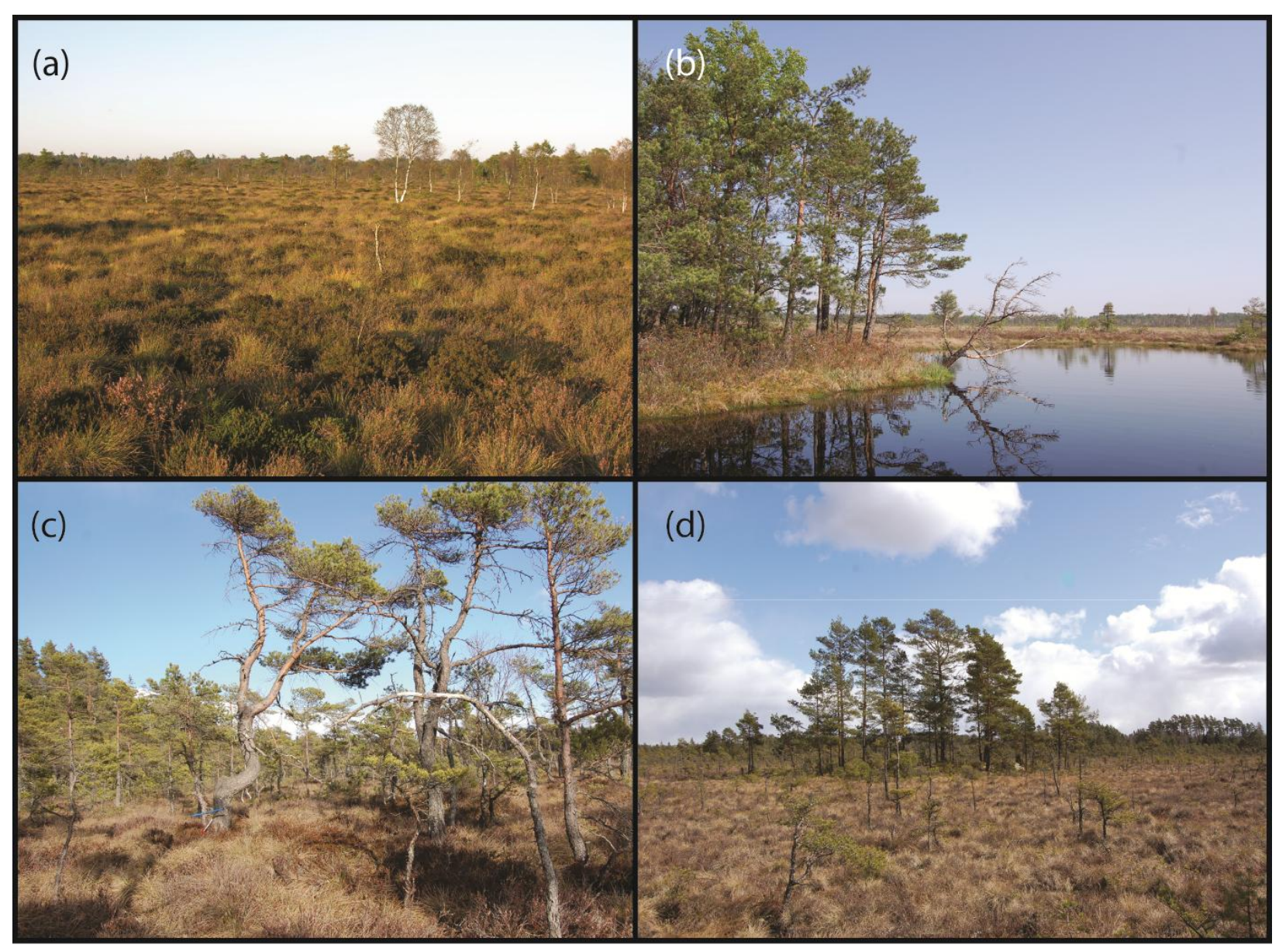


Fig. 4

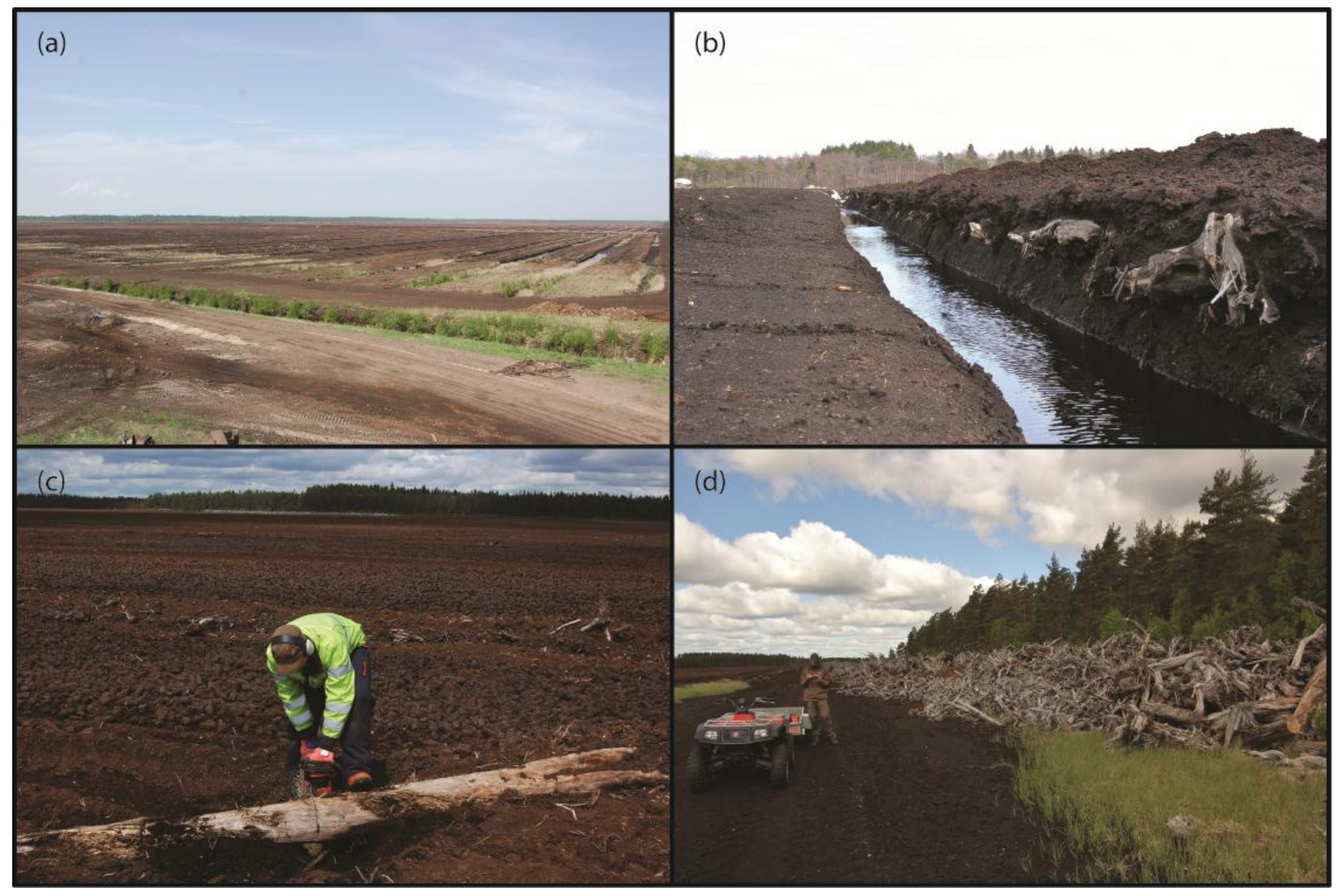

Fig. 5 


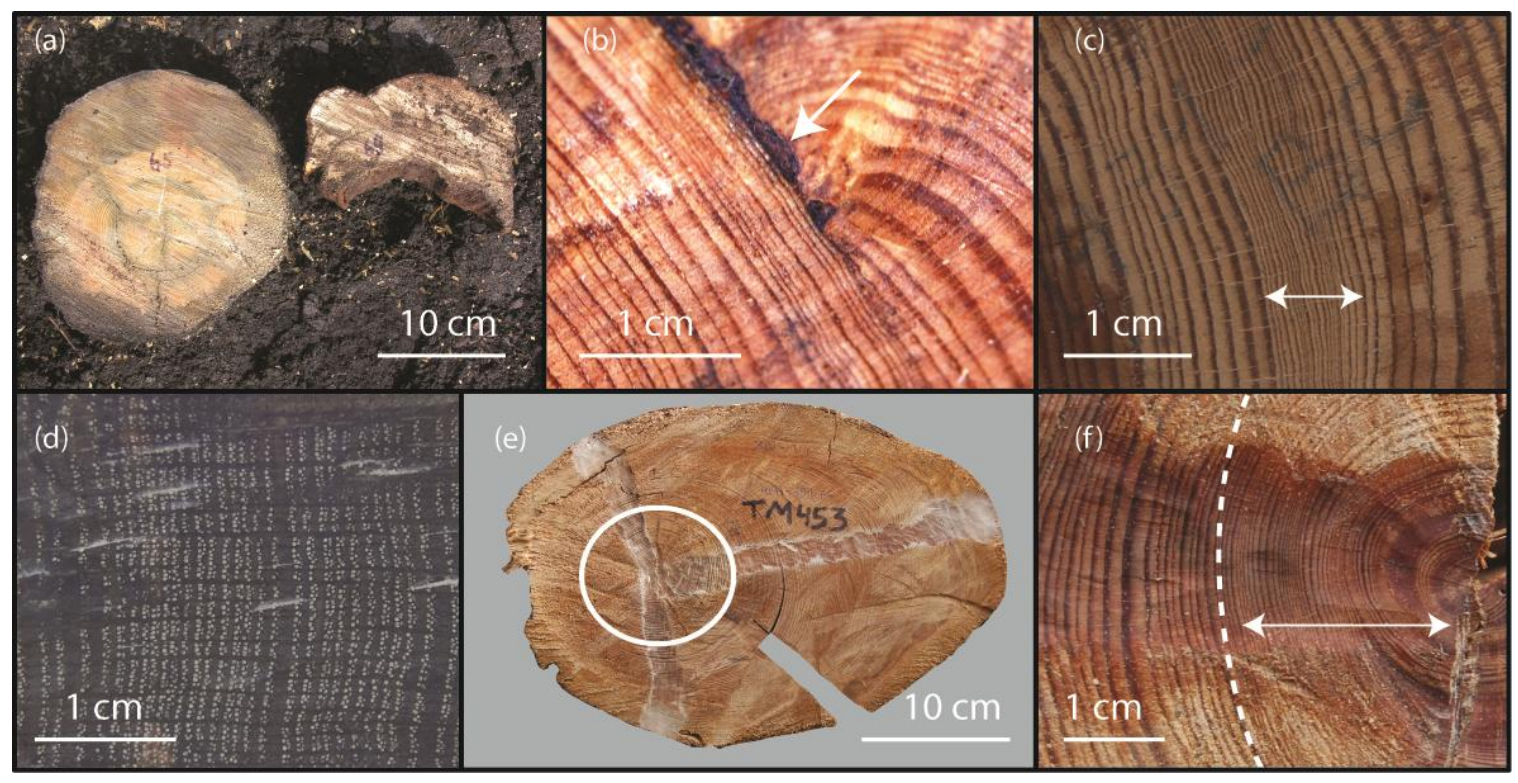

Fig. 6 


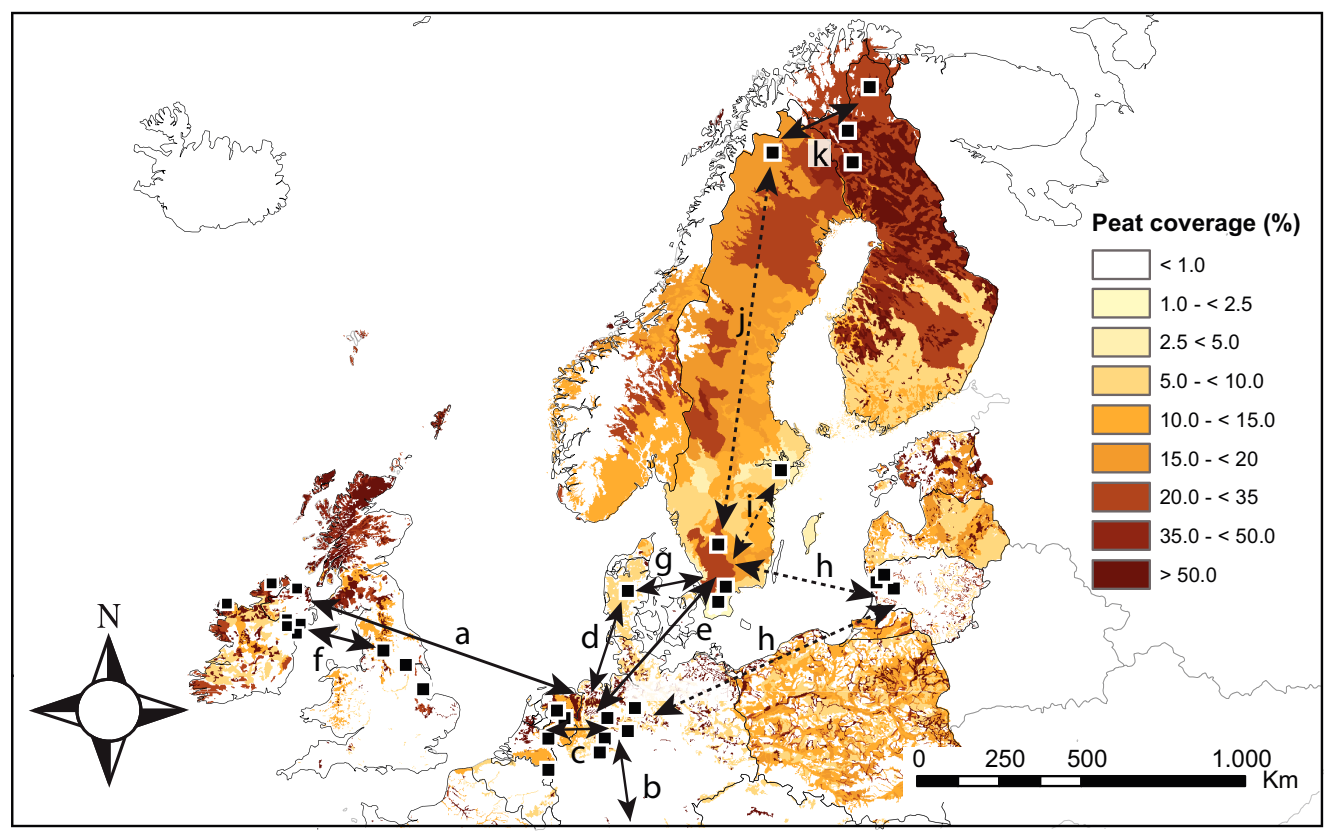

Fig. 7 


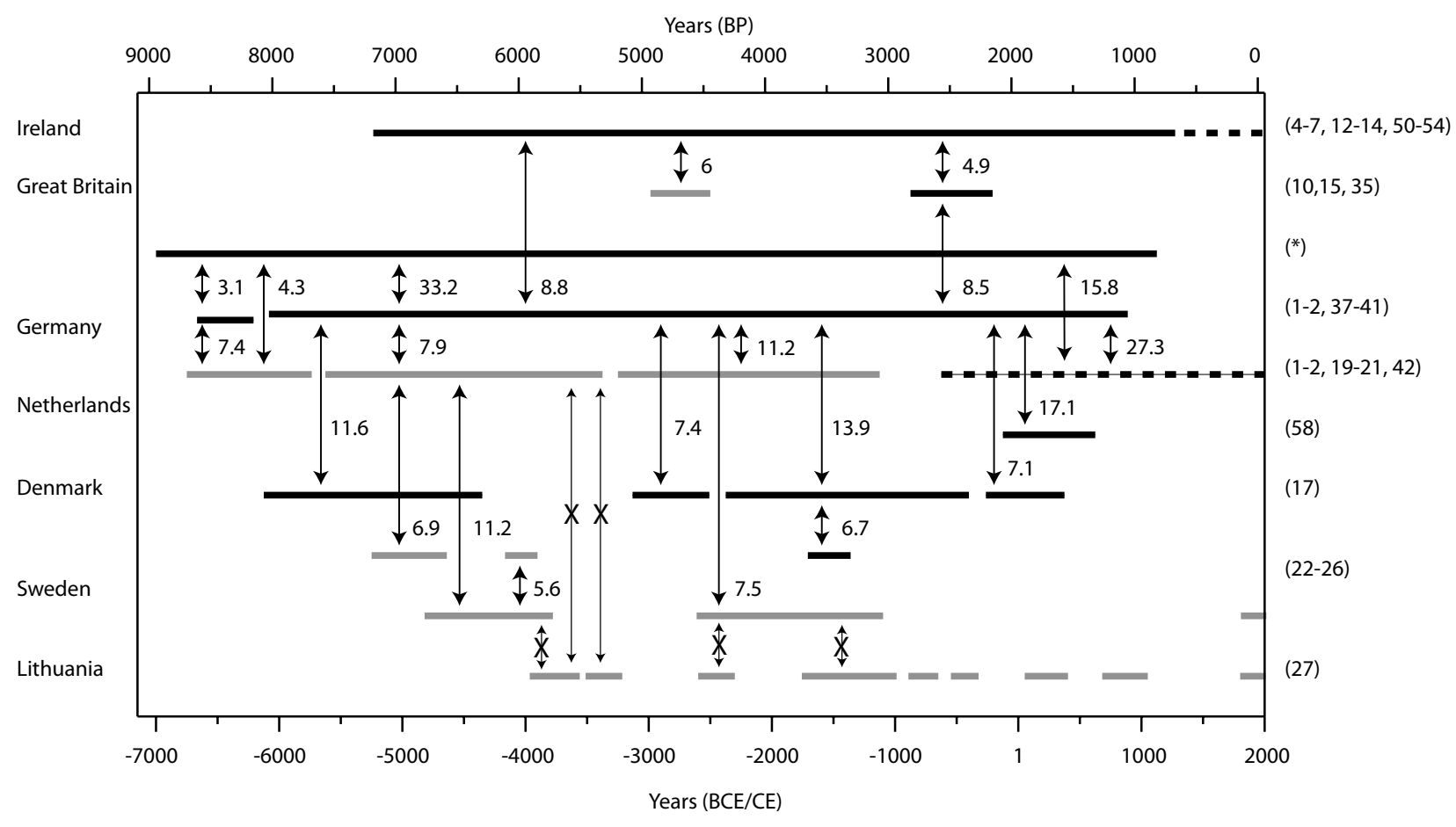

Fig. 8 
Months

Id. No. Soil Species $m$ j j a s o $n$ d J F M A M J J A S O Parameter

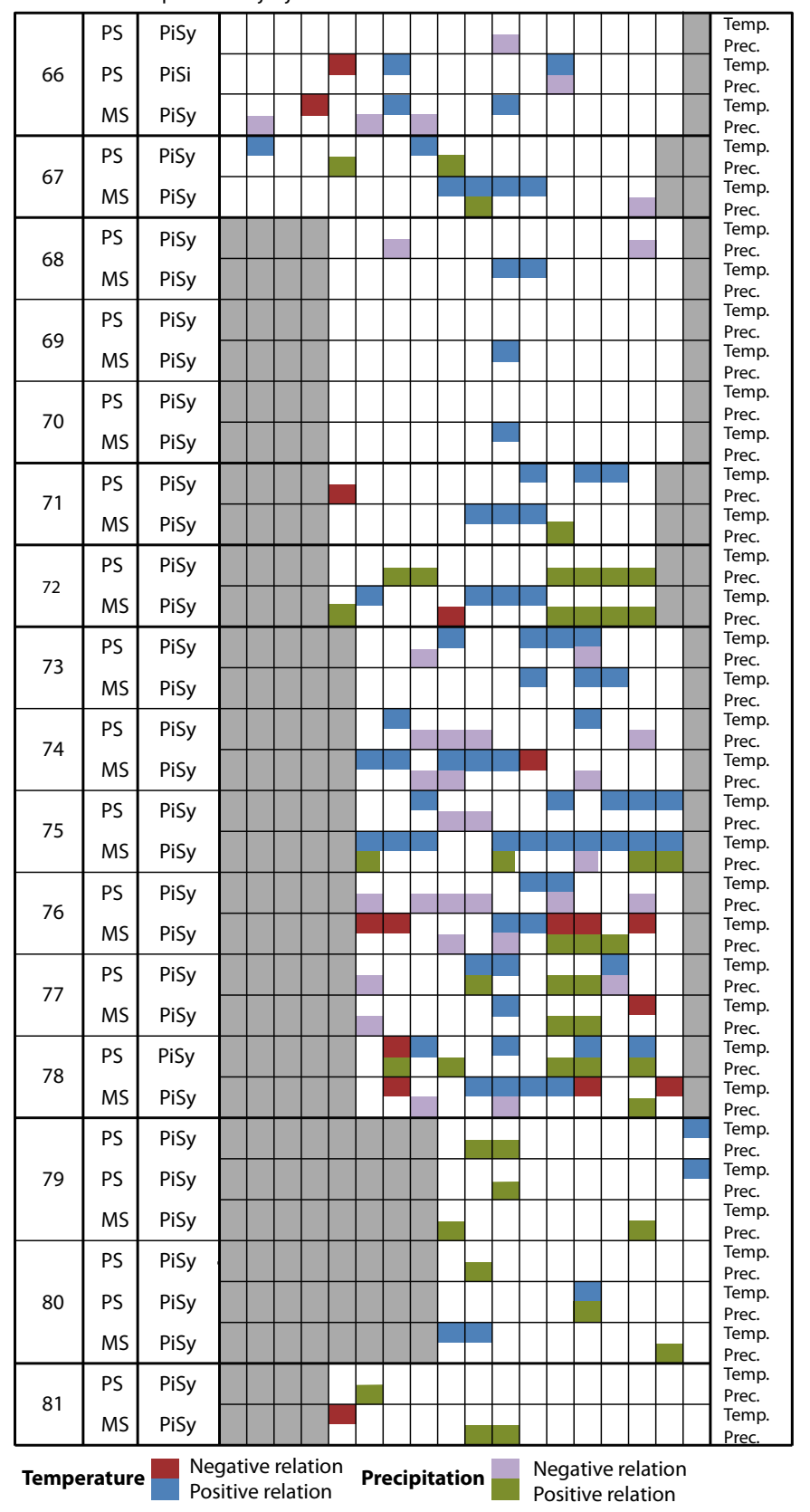

Fig. 9 


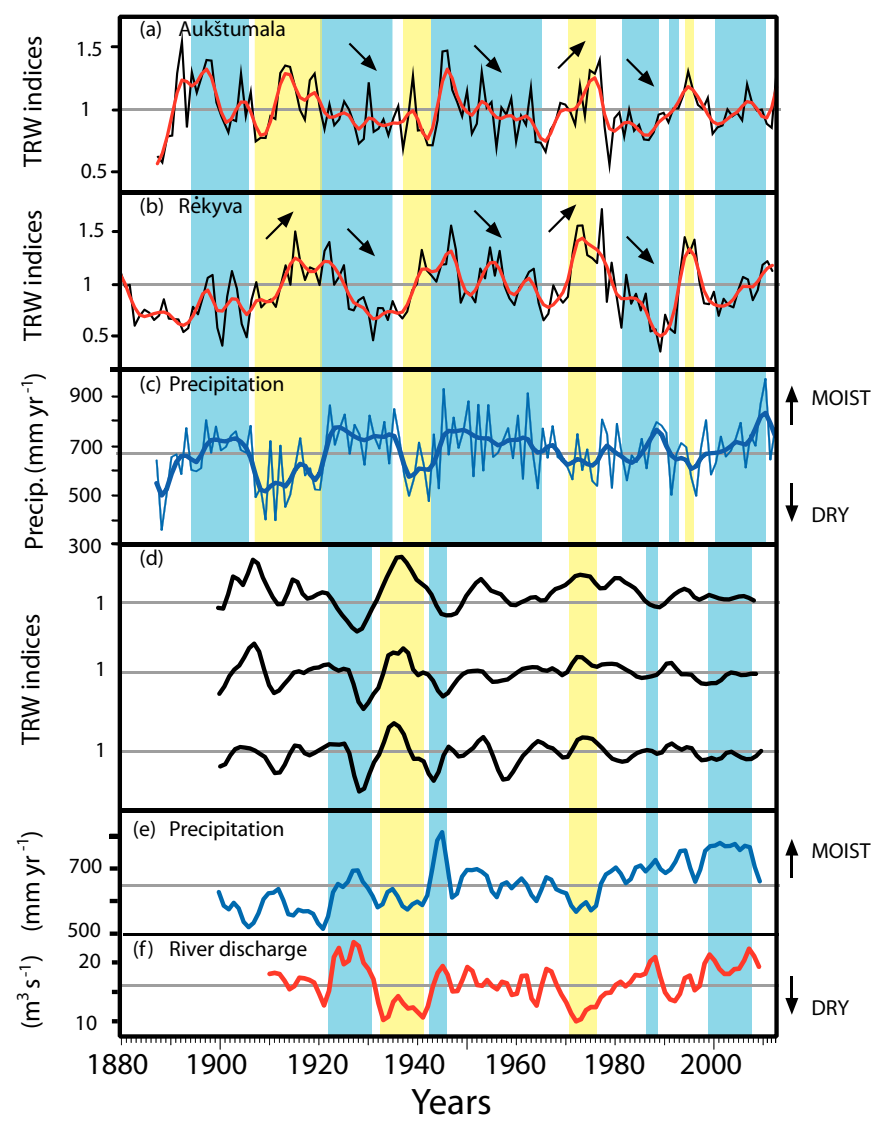

Fig. 10 


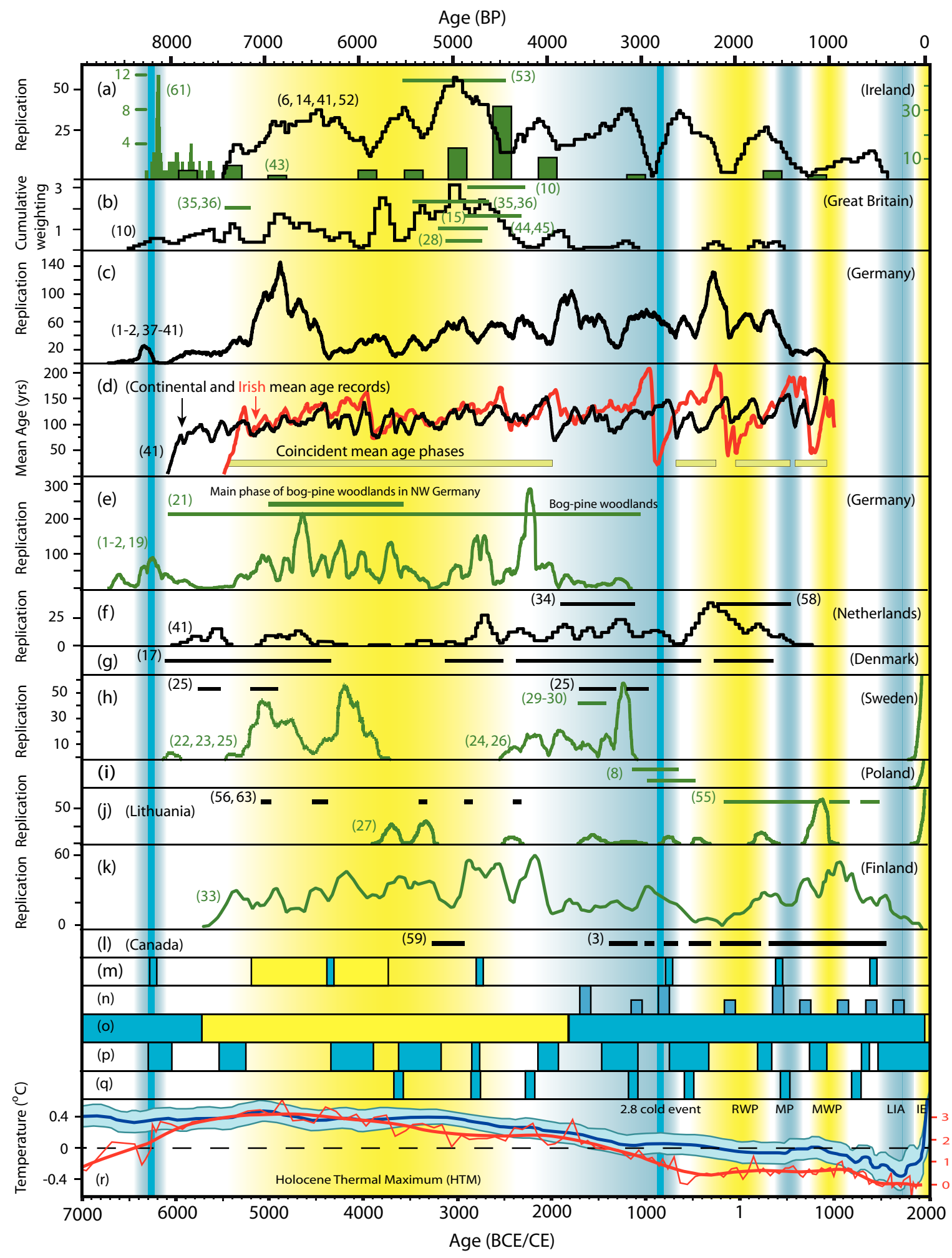

Fig. 11 


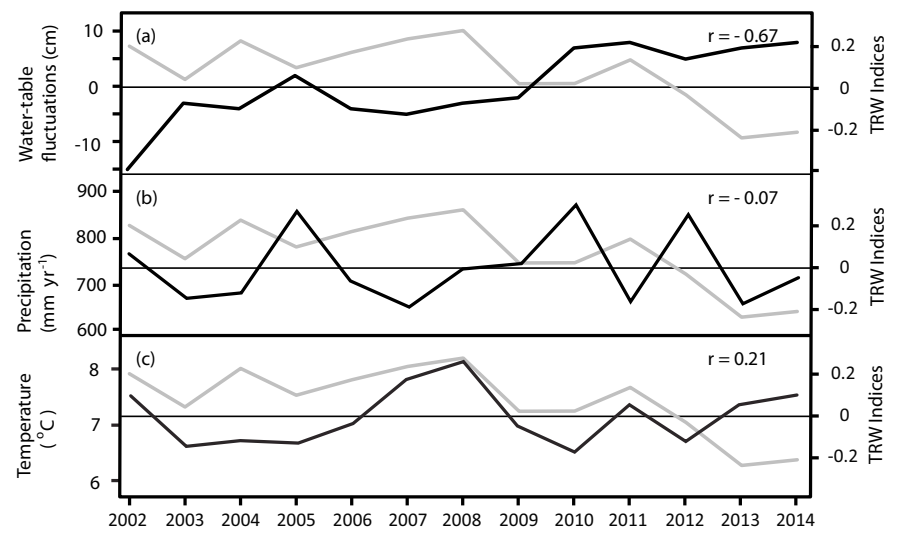

Years 